\title{
A short story of nearly everything in Lactifluus (Russulaceae)
}

\author{
E. De Crop $^{1 *}$, L. Delgat ${ }^{1,2}$, J. Nuytinck ${ }^{1,3}$, R.E. Halling ${ }^{4}$, A. Verbeken ${ }^{1}$ \\ ${ }^{1}$ Ghent University, Department of Biology, Research group Mycology, K. L. Ledeganckstraat 35, 9000 Ghent, Belgium \\ ${ }^{2}$ National Botanic Garden of Belgium (BR), Research Department, Domein van Bouchout, 1860 Meise, Belgium \\ ${ }^{3}$ Naturalis Biodiversity Center, P.O. Box 9517, 2300 RA Leiden, The Netherlands \\ ${ }^{4}$ The New York Botanical Garden, Institute of Systematic Botany, Bronx, NY 10458 USA \\ *Corresponding author: Eske.DeCrop@UGent.be
}

\section{Key words:}

ectomycorrhizal fungi

fungal diversity

Lactarius

milkcaps

Russulales

\begin{abstract}
Fungi are a large and hyper-diverse group with major taxa present in every ecosystem on earth. However, compared to other eukaryotic organisms, their diversity is largely understudied. Since the rise of molecular techniques, new lineages are being discovered at an increasing rate, but many are not accurately characterised. Access to comprehensive and reliable taxonomic information of organisms is fundamental for research in different disciplines exploring a variety of questions. A globally dominant ectomycorrhizal (ECM) fungal family in terrestrial ecosystems is the Russulaceae (Russulales, Basidiomycota) family. Amongst the mainly agaricoid Russulaceae genera, the ectomycorrhizal genus Lactifluus was historically least studied due to its largely tropical distribution in many underexplored areas and the apparent occurrence of several species complexes. Due to increased studies in the tropics, with a focus on this genus, knowledge on Lactifluus grew. We demonstrate here that Lactifluus is now one of the best-known ECM genera. This paper aims to provide a thorough overview of the current knowledge of Lactifluus, with information on diversity, distribution, ecology, phylogeny, taxonomy, morphology, and ethnomycological uses of species in this genus. This is a result of our larger study, aimed at building a comprehensive and complete dataset or taxonomic framework for Lactifluus, based on molecular, morphological, biogeographical, and taxonomical data as a tool and reference for other researchers.
\end{abstract}

Citation: De Crop E, Delgat L, Nuytinck J, Halling RE, Verbeken A (2021). A short story of nearly everything in Lactifluus (Russulaceae). Fungal Systematics and Evolution 7: 133-164. doi: 10.3114/fuse.2021.07.07

Received: 7 October 2019; Accepted: 8 January 2021; Effectively published online: 1 February 2021

Corresponding editor: P.W. Crous

\section{INTRODUCTION}

\section{Fungal diversity and the need for a solid taxonomic framework}

Fungi are one of the largest and most diverse groups of organisms on Earth. There are currently about 148000 fungal species described (Cheek et al. 2020), but recent studies estimate that this is only a fraction of a total of $2.2(6.5 \%)-3.8$ (3.8\%) M fungal species (Hawksworth 2001, O'Brien et al. 2005, Schmit \& Mueller 2007, Blackwell 2011, Hawksworth \& Lücking 2017). Compared to flowering plants or vertebrates, where $80-$ $90 \%$ of estimated species numbers are described (Convention on Biological Diversity, CBD 2006, Pimm \& Joppa 2015, Kew 2016), there is a major gap for fungi. The majority of fungi are undescribed; many are microscopic and cannot be cultured, many lineages have only been recovered with environmental sequencing, or they exist in remote and un- or underexplored areas. Likewise, even mushroom-forming lineages contain many undescribed taxa (Blackwell 2011).

One ecological guild with many mushroom-forming lineages is the ectomycorrhizal (ECM) fungi. Although various ECM fungi are well-studied, many species remain undiscovered or undescribed. For example, a seven-year-long study of ECM fungi in the Guiana Shield (Guyana) led to the discovery of one new ECM genus (Sanchez-Garcia et al. 2016) and new taxon discovery rates were estimated to be around 60-70\% (Henkel et al. 2012). In tropical Africa, Verbeken \& Buyck (2002) estimated the number of all undescribed ECM species to be double the number of described taxa.

This large gap between the estimated and the actual described number of fungal species became especially obvious since the development of next generation sequencing (NGS) tools, where one soil sample could reveal hundreds of potential new species (e.g. in Tedersoo et al. 2014). The use of these techniques results in a much faster molecular "species" discovery (operational taxonomical units, OTU's) than the more traditional species discovery, based on a combination of morphology, molecular data and species delimitation techniques. Unfortunately, as most fungal groups are still underexplored, the majority of these OTU's remain unidentified, especially at species level.

A solid taxonomic framework is needed by which the metagenomic sequences generated can be compared and linked to actual species. The existence of such a framework is rare, especially in tropical or underexplored areas, while when extant, it often only holds basic information. This has major 
complications regarding the conclusions that can be drawn from such incomplete data. The compilation of detailed species descriptions, however, is a meticulous and time-consuming task, and a morphological description tied to a physical type specimen is needed at a minimum. This is not always easily available for fungi, for example for many microscopic fungi (Taylor et al. 2006, Hibbett 2016), or for species only known from environmental sequences.

The predominantly tropical ECM genus Lactifluus (Russulaceae) has been extensively studied during recent years, resulting in the availability of a solid phylogeny, combined with a revised taxonomy (De Crop et al. 2017). With this review, we want to contribute to the knowledge of this genus and supplement its taxonomic framework with detailed information on diversity, morphology, and ecology. We give an overview of all 224 described Lactifluus species, accompanied by information on their subgeneric classification and quality of those data. We discuss the distribution of Lactifluus species and their ecology, and we explore publicly available metabarcoding data and discuss their impact on our current knowledge of Lactifluus. We provide a thorough overview of macro- and microscopical features of Lactifluus species and discuss their use as renewable natural resources.

\section{Russulales}

In 1796 and 1797, Persoon described the genera Russula and Lactarius as discrete genera of agaricoid fungi, differing primarily from other genera by their brittle context. Russula species have sporocarps with strikingly coloured caps and Lactarius species exude a milk-like solution (latex) when sporocarps are bruised (Persoon 1796, 1797). Due to their striking morphological characteristics, Lactarius and Russula were later classified in their own order, Russulales, within Agaricomycetes with pale-coloured spores (Kreisel 1969, Oberwinkler 1977). Morphologically, this classification was mainly supported by microscopical features such as sphaerocytes in the trama, responsible for the brittle context, amyloid spore ornamentation and a gloeoplerous hyphal system (i.e. hyphae with long cells that contain numerous oil droplets in the cytoplasm; Fig. 1). Combinations of these characters were also found in several taxa with other basidiocarp types and were included in this order (Romagnesi 1948, Donk 1971, Oberwinkler 1977). Next to the agaricoid Russula and Lactarius, Russulales further comprised coral fungi (Artomyces; Jülich 1981), poroid fungi (Heterobasidion), hydnoid fungi (Echinodontium, and Hericium) and corticioid fungi (Gloeocystidiellum, Boidinia, and Gloiothele).
Over the last two decades, molecular phylogenetic research contributed to a revision of the Russulales. Molecular data showed strong support for a russuloid clade with corticioid, resupinate, discoid, clavarioid, pileate, effused-reflexed, and gasteroid taxa with smooth, poroid, hydnoid, lamellate or labyrinthoid hymenophores (Fig. 2), but not all shared sphaerocytes and amyloid spore ornamentation (Hibbett et al. 1997, Hibbett \& Binder 2002, Larsson \& Larsson 2003, Larsson et al. 2004, Miller et al. 2006, Buyck et al. 2008). The Russulales order is morphologically supported by the presence of gloeocystidia or a gloeoplerous hyphal system (Larsson \& Larsson 2003, Miller et al. 2006).

Russula, Lactarius and some pleurotoid and sequestrate genera form a discrete group within this clade and circumscribe the Russulaceae (Redhead \& Norvell 1993, Miller et al. 2001, Larsson \& Larsson 2003, Eberhardt \& Verbeken 2004, Nuytinck et al. 2004).

\section{Russulaceae}

Before 2000, Russulaceae classification was mainly based on morphological characters such as sporocarp type. Agaricoid species were placed in Russula and Lactarius. Pleurotoid species were placed in Pleurogala. Sequestrate species were classified as Arcangeliella, Gastrolactarius, Zelleromyces, Cystangium, Elasmomyces, Gymnomyces, Martellia and Macowanites. Veiled species were placed in the genus Lactariopsis. Generic concepts in the mushroom-forming Russulaceae changed when hypotheses were advanced that pleurotoid, sequestrate and veiled forms originated several times, both in Lactarius and Russula. Morphological and molecular studies of pleurotoid Russulaceae species (Verbeken 1998, Buyck \& Horak 1999, Henkel et al. 2000), supported placement in either Russula or Lactarius. Hence, Pleurogala (Redhead \& Norvell 1993) was abandoned. Likewise, sequestrate species originally allied to Lactarius (Arcangeliella, Gastrolactarius and Zelleromyces) and Russula (Cystangium, Elasmomyces, Gymnomyces, Martellia and Macowanites) were reclassified (Calonge \& Martín 2000, Miller et al. 2001, Binder \& Bresinsky 2002, Desjardin 2003, Nuytinck et al. 2003, Eberhardt \& Verbeken 2004, Lebel \& Tonkin 2007, Verbeken et al. 2014). Species with a velum occur both in Lactarius and Russula. This is in line with the standpoint of Verbeken (1998) and abandons the separate genus in which they were placed by other authors (Hennings 1902, Heim 1937, Redhead \& Norvell 1993). From 2003 on, molecular analyses indicated that Russulaceae also contains several corticioid taxa from three genera: Boidinia,
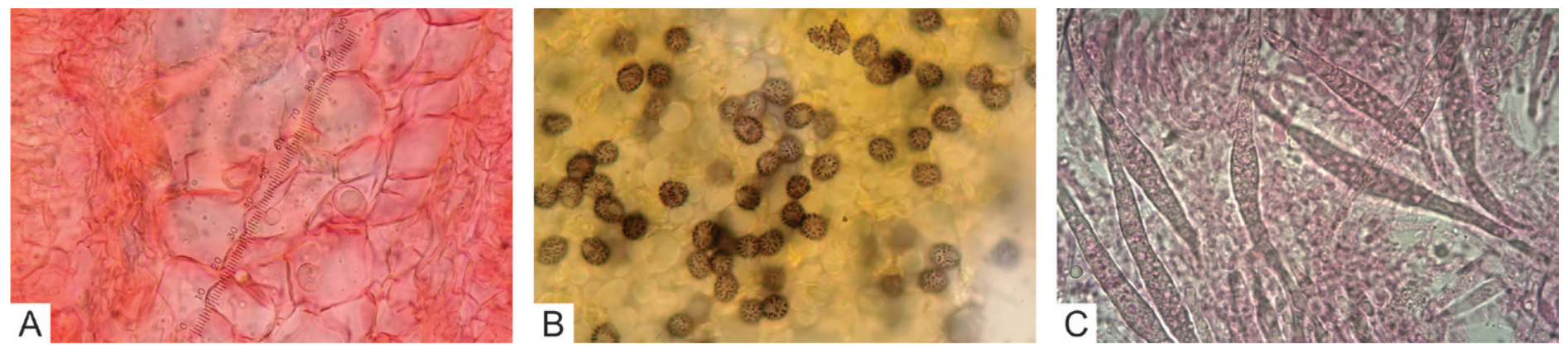

Fig. 1. A. Sphaerocytes within the trama of Lactifluus sp. (EDC 14-060). B. Amyloid spore ornamentation of Lf. russulisporus (REH 9398). C. Gloeocystidia in Gloeocystidiellum porosum [Photographs by E. De Crop (A, B) and N. Schoutteten (C)]. 
Gloeopeniophorella and Pseudoxenasma (Larsson \& Larsson 2003, Miller et al. 2006).

Buyck et al. (2008) constructed a phylogeny of the agaricoid Russulaceae genera. They focused on more tropical taxa than previous studies. In some cases, tropical Lactarius and Russula species turned out to be indistinguishable from each other based on morphology. Their results showed that Lactarius and Russula were not two well-defined and separate clades. Russula appears to be monophyletic only if a small group of species is excluded. The genus Russula sensu Buyck et al. (2008) is the largest Russulaceae genus, with more than 750-900 species described all over the world (Kirk et al. 2008, Buyck \& Atri 2011, Looney et al. 2016). The majority of Russula species is agaricoid, but some are pleurotoid or sequestrate, and veiled species are also known (Fig. 3). All species lack latex production and lack pseudocystidia. They are characterised by a brittle context caused by sphaerocytes in the context and trama, and by the presence of bright pigments, especially in the cap (usually contrasting with a white or whitish stipe and gills that vary from white to yellow, depending on the colour of the spores).
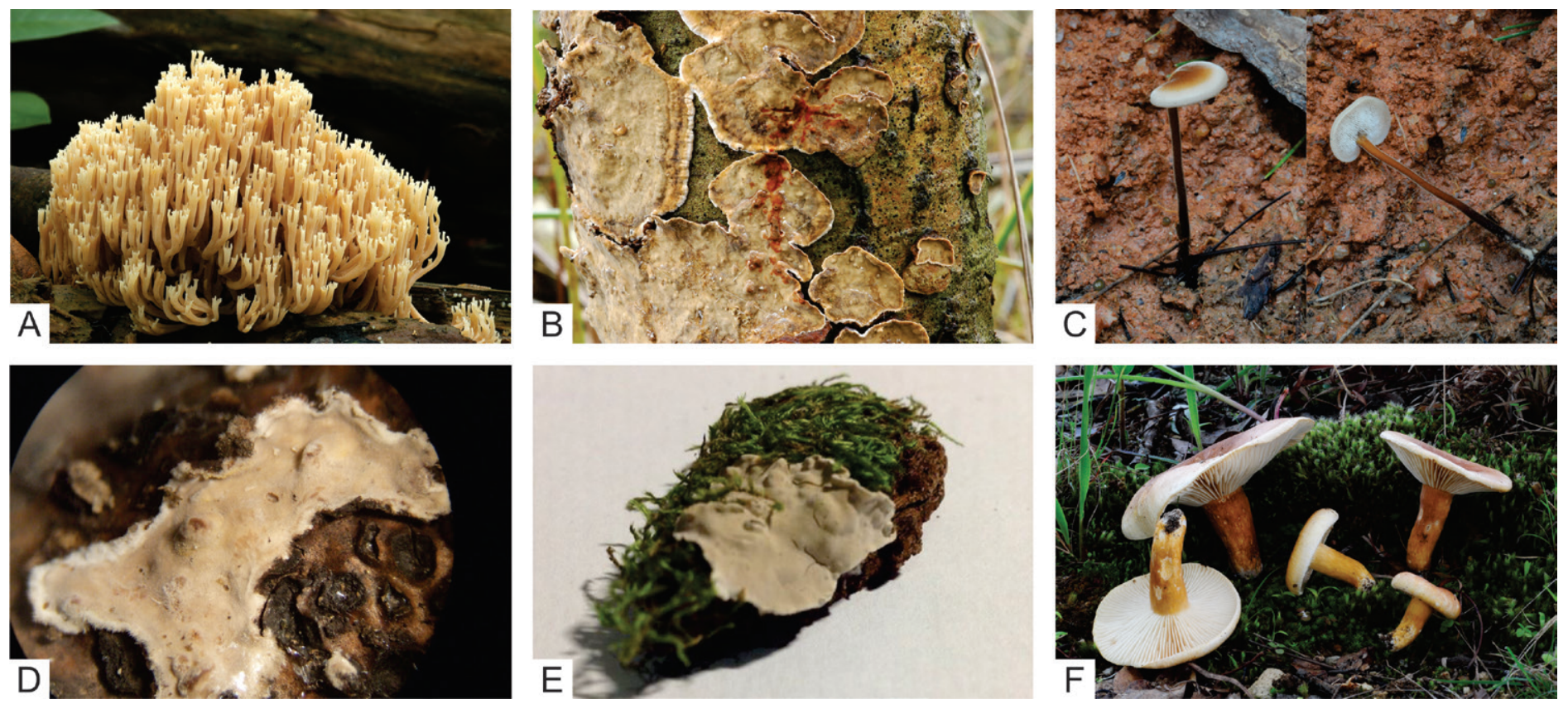

Fig. 2. Different types of sporocarps and hymenophores within the Russulales. A. Clavarioid sporocarp of Artomyces pyxidatus. B. Effused-reflexed sporocarps with smooth hymenium of Stereum rugosum. C. Pileate sporocarp with hydnoid hymenium of Auriscalpium sp. (EDC 14-511). D. Resupinate sporocarp with smooth hymenium of Peniophora incarnata. E. Discoid sporocarp with smooth hymenium of Aleurodiscus disciforme. F. Pileate sporocarp with lamellate hymenium of Lactifluus urens (EDC 12-032) [Photographs by R. Walleyn (A, B), E. De Crop (C, F) and N. Schoutteten (D, E)].
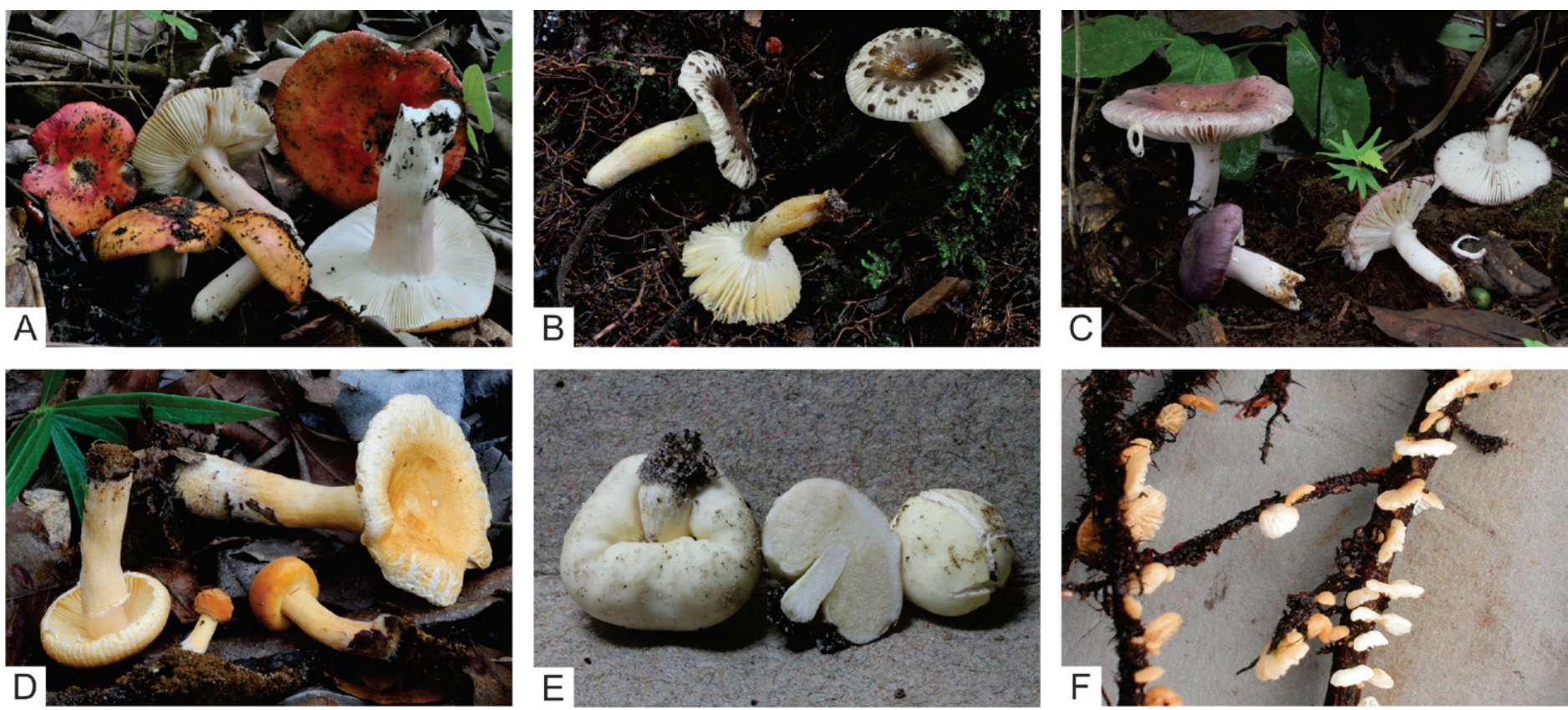

Fig. 3. Different Russula species. A. Agaricoid species Russula sp. (EDC 12-063). B. Agaricoid species Russula sp. (EDC 12-058). C. Annulate agaricoid species Russula sp. (EDC 14-381). D. Annulate agaricoid species Russula sp. (EDC 14-040). E. Secotoid species Russula sp. (former Macowanites sp.) (REH 9496). F. Pleurotoid species R. campinensis (TH 9252) [Photographs by E. De Crop (A-D), R. Halling (E) and T. Henkel (F)]. 
A small group of species excluded from the former Russula forms a clade together with some Lactarius species. This clade was described as the new genus Multifurca (Buyck et al. 2008). The former Russula subsect. Ochricompactae, the Asian species Russula zonaria and the American species Lactarius furcatus were included in this genus. Multifurca species are characterised by furcate lamellae, dark yellowish lamellae and spore-prints, a strong zonation of pileus and context (Fig. 4). Latex is only present in some Multifurca species and the presence of latex seems to be a variable character in this genus, even within one species. Only 11 Multifurca species are currently known (Buyck et al. 2008, Wang \& Liu 2010, Lebel et al. 2013, Wang et al. 2018) from three biogeographic regions: Asia, Australasia and North/ Central America.

The remainder of Lactarius was split in two different clades (Buyck et al. 2008). One large clade contained the majority of described milkcap species (about $75 \%$ of those known) and one smaller clade with mainly tropical species. At that time, this smaller clade contained the type species of Lactarius: Lactarius piperatus. A proposal to conserve Lactarius (hereafter abbreviated as L.) with a conserved type species, Lactarius torminosus was accepted (Buyck et al. 2010, McNeill et al. 2011) and the name Lactarius has been retained for the larger clade (Fig. 5). The subgenera $L$. subg. Lactarius (the former $L$. subg. Piperites), L. subg. Russularia, and L. subg. Plinthogalus, together with several undescribed tropical lineages that need to be described at subgenus level (Nuytinck et al. 2020), now constitute the larger milkcap genus Lactarius sensu Buyck et al. (2008), Buyck et al. (2010). Approximately 450 species are accepted in Lactarius, which occurs worldwide but has its main distribution in the temperate and boreal regions.

The smaller milkcap group, with approximately 200 described species, is named Lactifluus (hereafter abbreviated as $L f$.) and is automatically typified by Agaricus lactifluus, currently known as Lf. volemus (Buyck et al. 2010). New combinations were made in a series of three papers for the different subgenera (Verbeken et al. 2011, Stubbe et al. 2012b, Verbeken et al. 2012).

The two milkcap genera, Lactarius and Lactifluus, are wellsupported based on molecular inference, but no synapomorphic characteristics have been found to consistently separate both genera. The morphological distinction between the genera is thus far based on several trends:

Characteristics of the pileus - Lactifluus is generally characterised by the complete absence of zonate and viscose to glutinous caps, while it contains many species with velvety caps, and even some with veiled caps. Lactarius however, contains
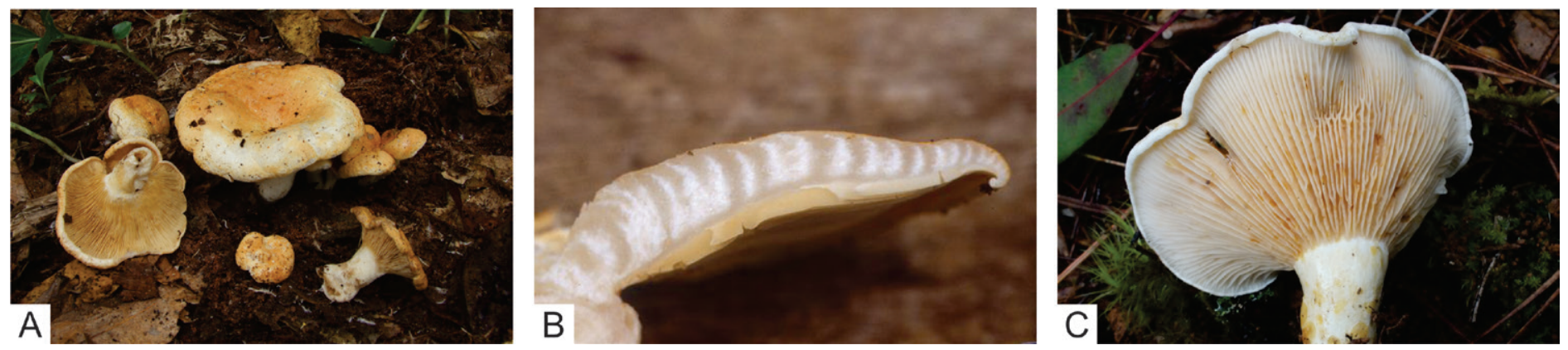

Fig. 4. Different Multifurca species. A. M. zonaria (FH 12-009). B. Detail on zonate context of M. zonaria. C. M. pseudofurcata (xp2-20120922-01) [Photographs by F. Hampe (A), A. Verbeken (B) and G. Jiayu (C)].
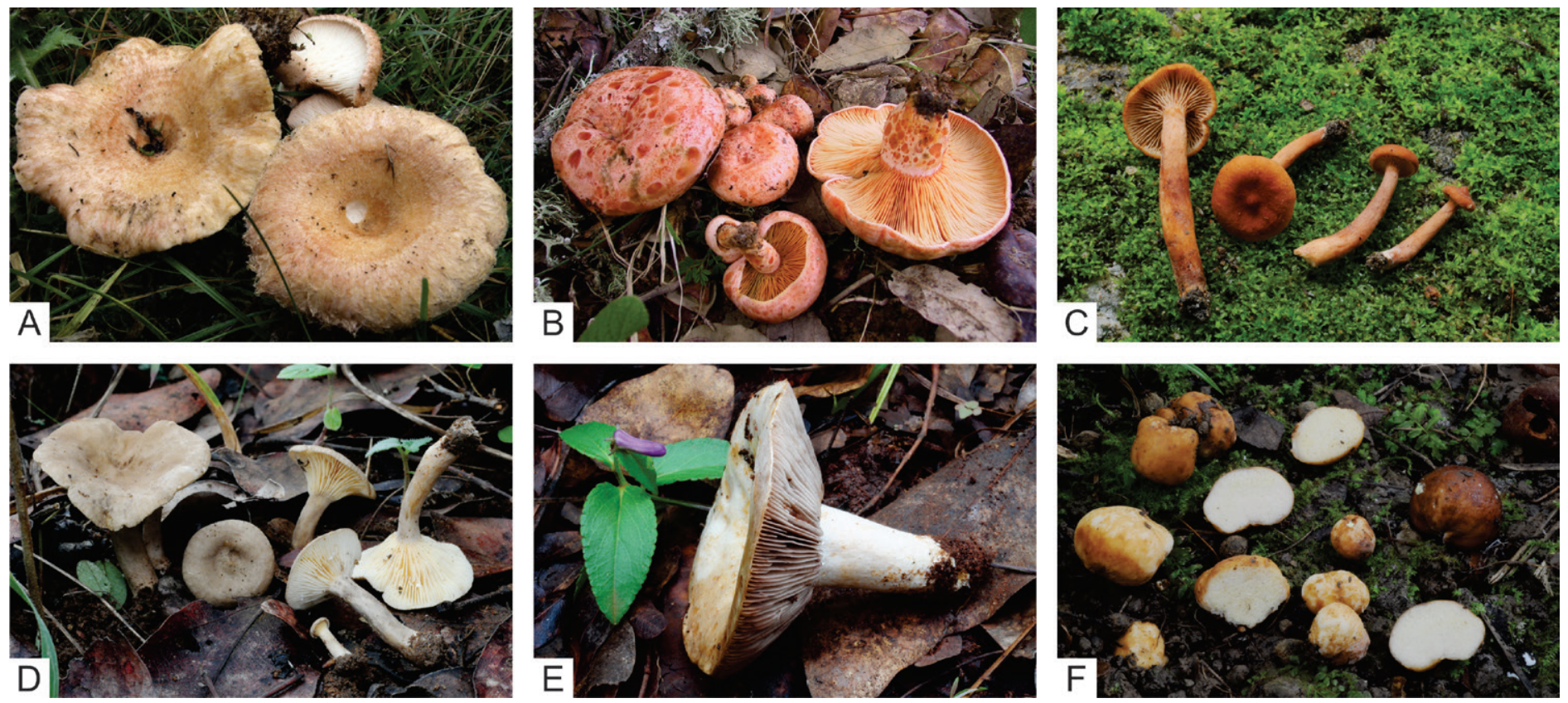

Fig. 5. Different Lactarius species. A. L. torminosus (JN 2011-087). B. L. deliciosus (JN 2003-055). C. L. lacunarum. D. L. tenellus (EDC 14-064). E. L. chromospermus (EDC 14-108). F. L. stephensii (EDC 14-575) [Photographs by J. Nuytinck (A, B), A. Verbeken (C) and E. De Crop (D-F)]. 
many species with zonate and viscose to glutinous caps (Verbeken \& Nuytinck 2013). Veiled species are not known in Lactarius.

Sporocarp characteristics - pleurotoid milkcap species are so far only known in Lactifluus (Buyck et al. 2008, Verbeken \& Nuytinck 2013), sequestrate species are most common in Lactarius, but were recently found to occur in Lactifluus too (Lebel et al. 2016).

Hymenophoral trama - the hymenophoral trama of Lactifluus species is mostly composed of sphaerocytes, which is also common in Russula (Verbeken \& Nuytinck 2013). In contrast, these sphaerocytes are only rarely observed in Lactarius species, where the hymenophoral trama most often is composed of filamentous hyphae only.

Thick-walled elements - thick-walled elements in the pileipellis, stipitipellis and hymenophoral trama are common in the genus Lactifluus, while they are hardly observed in the genus Lactarius (Verbeken \& Nuytinck 2013).

These features might be helpful when identifying milkcap species, but they are not exclusive. There are species, especially in the tropics, in which a molecular characterisation is needed to determine to which genus they belong.

\section{THE GENUS LACTIFLUUS}

\section{Diversity and distribution}

The milkcap genus Lactifluus is predominantly present in the tropics. Mainly due to this distribution, Lactifluus has long been understudied compared to its sister Lactarius. Before the start of our study of the genus Lactifluus at the end of 2010, the highest diversity of the genus was known from sub-Saharan Africa, with 60 species described (Verbeken \& Walleyn 2010), and Asia, with 23 species described (Le et al. 2007, Stubbe et al. 2010, Van de Putte et al. 2010). However, the genus also appears to be well-represented in South America, as new species are being discovered since more South American habitats are being explored (Henkel et al. 2000, Miller et al. 2002, Smith et al. 2011, Sá et al. 2013, Sá \& Wartchow 2013, Crous et al. 2017, Delgat et al. 2019, 2020, Duque Barbosa et al. 2020), and the majority of the proposed South American Lactarius species turns out to belong in Lactifluus (Pegler \& Fiard 1979, Singer et al. 1983, Miller et al. 2002). Since 2010, 78 new Lactifluus species have been described: 34 from Asia (Stubbe et al. 2012a, Van de Putte et al. 2012, Wang et al. 2012, 2015, Morozova et al. 2013, Latha et al. 2016, Li et al. 2016, Uniyal et al. 2016, Zhang et al. 2016, Das et al. 2017, Hyde et al. 2017, Song et al. 2017, De Crop et al. 2018, Liu et al. 2018, Song et al. 2018, Bera \& Das 2019, Dierickx et al. 2019a, b, Phookamsak et al. 2019), 16 from Africa (De Crop et al. 2012, Maba et al. 2014, 2015a, b, De Crop et al. 2016, 2019, Delgat et al. 2017, De Lange et al. 2018), 20 from the Neotropics (Miller et al. 2012, Montoya et al. 2012, Sá et al. 2013, Sá \& Wartchow 2013, Wartchow et al. 2013, Crous et al. 2017, 2019, Delgat et al. 2019, 2020, Sá et al. 2019, Duque Barbosa et al. 2020, Silva et al. 2020), seven from Australasia (Stubbe et al. 2012a, Kropp 2016, Dierickx et al. 2019a, b, Crous et al. 2020a, b), and one species from Europe (Van de Putte et al. 2016). This brings the total number of described Lactifluus species to 226 . However, recent phylogenetic studies suggest that there are more lineages that represent new species (De Crop et al. 2017; Delgat \& De Crop unpubl.). De Crop (2016) performed a worldwide phylogeny of 1306 Lactifluus ITS sequences on which species were delimited using the GMYC method (Pons et al.
2006). This resulted in 369 putative Lactifluus species. Based on this number of species and using a species accumulation curve, the total number of Lactifluus species was estimated to be around 530 species (De Crop 2016, He et al. 2019, Nuytinck et al. 2020). Although this is a rough estimate, it indicates that the majority of Lactifluus species is still undescribed. Many known specieslevel clades are not described yet because they lack detailed documentation, or they are singletons, and describing species is a laborious work.

So far, none of the Lactifluus species occurs with certainty on two or more continents (Table 1). Although, some species records used to suggest otherwise. For example, collections identified as the North American Lf. luteolus based on morphology were also found in Europe, Asia and Australia. All collections have typical cream-beige sporocarps, which exude white milk that quickly stains brownish. However, a recent molecular study of Dierickx et al. (2019b) showed that Lf. luteolus is a North American species. The records from other continents represent different species. Another example is the North American species $L f$. hygrophoroides which was also reported from Asia. However, preliminary molecular results show the existence of multiple clades identified as $L f$. hygrophoroides, each clade occurring on one continent, instead of one intercontinental species (De Crop, unpubl.). The recently described Australian species Lf. austropiperatus forms a strongly supported clade with a Thai specimen, however, the authors maintain the Australian material as distinct until further collections from Thailand can be examined and sequenced (Crous et al. 2020b). In all other known cases of possible intercontinental species, molecular inference rejected this possibility (Stubbe et al. 2010, Van de Putte et al. 2010, De Crop et al. 2014).

In Russulaceae in general, intercontinental conspecificity appears to be rare. In Lactarius it seems to be more common than in Lactifluus. For example, Nuytinck et al. (2007) reported Lactarius deliciosus to occur in Europe and China, Nuytinck et al. (2010) found L. controversus to be conspecific between Europe and North America, and Wisitrassameewong (2015) reported L. badiosanguineus to occur both in Europe and China. Some records of species occurring on two or more continents are due to the introduction of their host trees in a new continent. For example, $L$. hepaticus was introduced in Madagascar and South Africa, when European Pinus trees were introduced for cultivation (Verbeken \& Walleyn 2010).

\section{Ecology}

Species of the genus Lactifluus are found in subtropical and tropical regions and to a lesser extent in temperate areas, in a wide range of vegetation types, including tropical and subtropical rain forests, subtropical dry forests, monsoon forests, tree savannahs, Mediterranean woodlands, temperate broadleaf and coniferous forests and montane forests. Basidiocarps are commonly found on soil, but in tropical habitats with high humidity they are sporadically found on stems or epigeous roots of trees, such as $L f$. brunellus on stems of Dicymbe corymbosa (Miller et al. 2002), Lf. multiceps and $L f$. raspei on plant seedlings (Fig. 6).

Lactifluus, Lactarius, Multifurca and Russula species are ectomycorrhizal fungi, while the corticioid Russulaceae taxa are reported to be saprotrophic (Larsson \& Larsson 2003, Miller et al. 2006, Tedersoo et al. 2010a). However, the latter is questioned by Miller et al. (2006), who suggest that these corticioid taxa might also be ectomycorrhizal symbionts. 
Table 1. List of described Lactifluus species, together with the current authors, the original publication, and biogeographical region of origin. Biogeographic regions are based on biogeographic realms (https://ecoregions2017.appspot.com/), with three major differences: Western Palearctic (Western part of the Palearctic realm), Asia (Eastern part of the Palearctic realm combined with the Indo-Malay realm), and Australasia (Australasian realm combined with the Oceanian realm). See Supplementary data (Figure S1) for an overview of the biogeographical regions used. Varieties of species are not included in this list. See supplementary data (Table S1) for more information on the classification of the Lactifluus species.

\begin{tabular}{|c|c|c|c|c|}
\hline & Name & Current authors & Original publication & Biogeographical region \\
\hline 1 & Lf. acicularis & (Van de Putte \& Verbeken) Van de Putte & Van de Putte et al. (2010) & Asia \\
\hline 2 & Lf. acrissimus & (Verbeken \& Van Rooij) Nuytinck & Van Rooij et al. (2003) & Afrotropics \\
\hline 4 & Lf. albocinctus & (Verbeken) Verbeken & Verbeken et al. (2000) & Afrotropics \\
\hline 5 & Lf. albomembranaceus & De Wilde \& Van de Putte & De Crop et al. (2016) & Afrotropics \\
\hline 8 & Lf. amazonensis & (Singer) Silva-Filho \& Wartchow & Singer et al. (1983) & Neotropics \\
\hline 9 & Lf. ambicystidiatus & X.H. Wang & Wang et al. (2015) & Asia \\
\hline 10 & Lf. angustifolius & (Hesler \& A.H. Sm.) De Crop & Hesler \& Smith (1979) & Nearctic \\
\hline 11 & Lf. angustus & (R. Heim \& Gooss.-Font.) Verbeken & Heim (1955) & Afrotropics \\
\hline 15 & Lf. arcuatus & (Murrill) Delgat & Murrill (1941) & Western Palearctic \\
\hline 16 & Lf. armeniacus & De Crop \& Verbeken & Li et al. (2016) & Asia \\
\hline 17 & Lf. arsenei & (R. Heim) Verbeken & Heim (1938) & Afrotropics \\
\hline 18 & Lf. atrovelutinus & (J.Z. Ying) X.H. Wang & Ying (1991) & Asia \\
\hline 19 & Lf. aurantiifolius & (Verbeken) Verbeken & Verbeken (1996a) & Afrotropics \\
\hline 20 & Lf. aurantiorugosus & Sá \& Wartchow & Sá \& Wartchow (2013) & Neotropics \\
\hline 21 & Lf. aurantiotinctus & Kropp & Kropp (2016) & Australasia \\
\hline 22 & Lf. aureifolius & (Verbeken) Verbeken & Verbeken (1996a) & Afrotropics \\
\hline 23 & Lf. auriculiformis & Verbeken \& Hampe & De Crop et al. (2018) & Asia \\
\hline 29 & Lf. bicapillus & Lescroart \& De Crop & De Crop et al. (2019) & Afrotropics \\
\hline 30 & Lf. bicolor & (Massee) Verbeken & Massee (1914) & Asia \\
\hline 31 & Lf. brachystegiae & (Verbeken \& C. Sharp) Verbeken & Verbeken et al. (2000) & Afrotropics \\
\hline 32 & Lf. brasiliensis & (Singer) Silva-Filho \& Wartchow & Singer et al. (1983) & Neotropics \\
\hline 33 & Lf. braunii & (Rick) Silva-Filho \& Wartchow & Rick (1930) & Neotropics \\
\hline 34 & Lf. brunellus & (S.L. Mill., Aime \& T.W. Henkel) De Crop & Miller et al. (2002) & Neotropics \\
\hline 35 & Lf. brunneocarpus & Maba & Maba et al. (2015a) & Afrotropics \\
\hline 36 & Lf. brunneoviolascens & (Bon) Verbeken & Bon (1971) & Western Palearctic \\
\hline 37 & Lf. brunnescens & (Verbeken) Verbeken & Verbeken (1996a) & Afrotropics \\
\hline 38 & Lf. burkinabei & Maba & Maba et al. (2015a) & Afrotropics \\
\hline 39 & Lf. caatingae & Sá \& Wartchow & Sá et al. (2019) & Neotropics \\
\hline 40 & Lf. caeruleitinctus & (Murrill) Delgat & Murrill (1939) & Western Palearctic \\
\hline 41 & Lf. caliendrifer & Froyen \& De Crop & Dierickx et al. (2019) & Asia \\
\hline 42 & Lf. caperatus & (R. Heim \& Gooss.-Font.) Verbeken & Heim (1955) & Afrotropics \\
\hline 43 & Lf. caribaeus & (Pegler) Verbeken & Pegler \& Fiard (1979) & Neotropics \\
\hline 44 & Lf. carmineus & (Verbeken \& Walleyn) Verbeken & Verbeken et al. (2000) & Afrotropics \\
\hline 45 & Lf. catarinensis & J. Duque, M.A. Neves \& M. Jaegger & Duque Barbosa et al. (2020) & Neotropics \\
\hline
\end{tabular}


Table 1. (Continued).

\begin{tabular}{|c|c|c|c|c|}
\hline & Name & Current authors & Original publication & Biogeographical region \\
\hline 47 & Lf. chamaeleontinus & (R. Heim) Verbeken & Heim (1955) & Afrotropics \\
\hline 49 & Lf. chrysocarpus & E. S. Popov \& O.V. Morozova & Morozova et al. (2013) & Asia \\
\hline 50 & Lf. claricolor & (R. Heim) Verbeken & Heim (1938) & Afrotropics \\
\hline 52 & Lf. coccolobae & (O. K. Miller \& Lodge) Delgat & Miller et al. (2000) & Neotropics \\
\hline 53 & Lf. cocosmus & (Van de Putte \& De Kesel) Van de Putte & Van de Putte et al. (2009) & Afrotropics \\
\hline 54 & Lf. conchatulus & (Stubbe \& H.T. Le) Stubbe & Stubbe et al. (2012) & Asia \\
\hline 55 & Lf. coniculus & Stubbe \& Verbeken & Stubbe et al. (2012) & Asia \\
\hline 59 & Lf. cyanovirescens & (Verbeken) Verbeken & Verbeken (1996a) & Afrotropics \\
\hline 60 & Lf. deceptivus & (Peck) Kuntze & Peck (1885) & Nearctic \\
\hline 61 & Lf. denigricans & (Verbeken \& Karhula) Verbeken & Verbeken (1996b) & Afrotropics \\
\hline 62 & Lf. densifolius & (Verbeken \& Karhula) Verbeken & Verbeken (1996a) & Afrotropics \\
\hline 63 & Lf. dinghuensis & Jianbin & Zhang et al. (2016) & Asia \\
\hline 64 & Lf. dissitus & Van de Putte, K. Das \& Verbeken & Van de Putte et al. (2012) & Asia \\
\hline 65 & Lf. distans & (Peck) Kuntze & Peck (1873) & Nearctic \\
\hline 66 & Lf. distantifolius & Van de Putte, Stubbe \& Verbeken & Van de Putte et al. (2010) & Asia \\
\hline 67 & Lf. domingensis & Delgat \& Angelini & Delgat et al. (2019) & Neotropics \\
\hline 74 & Lf. fazaoensis & Maba, Yorou \& Guelly & Maba et al. (2014) & Afrotropics \\
\hline 75 & Lf. flammans & (Verbeken) Verbeken & Verbeken (1995) & Afrotropics \\
\hline 76 & Lf. flavellus & Maba \& Guelly & Maba et al. (2015b) & Afrotropics \\
\hline 77 & Lf. flocktonae & (Cleland \& Cheel) Lebel & Cleland \& Cheel (1919) & Australasia \\
\hline 78 & Lf. foetens & (Verbeken) Verbeken & Van Rooij et al. (2003) & Afrotropics \\
\hline 79 & Lf. fuscomarginatus & (Montoya, Bandala \& Haug) Delgat & Montoya et al. (2012) & Neotropics \\
\hline 80 & Lf. genevievae & (Stubbe \& Verbeken) Stubbe & Stubbe et al. (2012) & Australasia \\
\hline 81 & Lf. gerardiellus & Wisitrassameewong \& Verbeken & De Crop et al. (2018) & Asia \\
\hline 82 & Lf. gerardii & (Peck) Kuntze & Peck (1874) & Nearctic \\
\hline 83 & Lf. glaucescens & (Crossl.) Verbeken & Crossland (1900) & Western Palearctic \\
\hline 84 & Lf. goossensiae & (Beeli) Verbeken & Beeli (1928) & Afrotropics \\
\hline 85 & Lf. guadeloupensis & Delgat \& Courtec. & Delgat et al. (2020) & Neotropics \\
\hline 86 & Lf. guanensis & Delgat \& Lodge & Crous et al. (2019) & Neotropics \\
\hline 87 & Lf. guellii & Maba & Maba et al. (2015a) & Afrotropics \\
\hline 88 & Lf. gymnocarpoides & (Verbeken) Verbeken & Verbeken (1995) & Afrotropics \\
\hline 89 & Lf. gymnocarpus & (R. Heim ex Singer) Verbeken & Singer (1948) & Afrotropics \\
\hline 90 & Lf. hallingii & Delgat \& De Wilde & Delgat et al. (2019) & Neotropics \\
\hline 91 & Lf. heimii & (Verbeken) Verbeken & Verbeken (1996a) & Afrotropics \\
\hline
\end{tabular}


Table 1. (Continued).

\begin{tabular}{|c|c|c|c|c|}
\hline & Name & Current authors & Original publication & Biogeographical region \\
\hline 95 & Lf. igniculus & O.V. Morozova \& E.S. Popov & Morozova et al. (2013) & Asia \\
\hline 97 & Lf. indicus & K.N.A. Raj \& Manim. & Latha et al. (2016) & Asia \\
\hline 98 & Lf. indovolemus & I. Bera \& K. Das & Bera \& Das (2019) & Asia \\
\hline 100 & Lf. inversus & (Gooss.-Font. \& R. Heim) Verbeken & Heim (1955) & Afrotropics \\
\hline 101 & Lf. kigomaensis & De Crop \& Verbeken & De Crop et al. (2012) & Afrotropics \\
\hline 102 & Lf. kivuensis & (Verbeken) Verbeken & Verbeken (1996a) & Afrotropics \\
\hline 103 & Lf. lactiglaucus & P. Leonard \& Dearnaley & Crous et al. (2020a) & Australasia \\
\hline 104 & Lf. laevigatus & (Verbeken) Verbeken & Verbeken (1996a) & Afrotropics \\
\hline 107 & Lf. leae & Stubbe \& Verbeken & Stubbe et al. (2012) & Asia \\
\hline 108 & Lf. leonardii & Stubbe \& Verbeken & Stubbe et al. (2012) & Australasia \\
\hline 109 & $L f$. leoninus & (Verbeken \& E. Horak) Verbeken & Verbeken \& Horak (1999) & Australasia \\
\hline 110 & Lf. leptomerus & Van de Putte, K. Das \& Verbeken & Van de Putte et al. (2012) & Asia \\
\hline 111 & Lf. lepus & Delgat \& Courtec. & Delgat et al. (2020) & Neotropics \\
\hline 112 & Lf. leucophaeus & (Verbeken \& E. Horak) Verbeken & Verbeken \& Horak (1999) & Australasia \\
\hline 113 & Lf. limbatus & Stubbe \& Verbeken & Stubbe et al. (2012) & Asia \\
\hline 114 & Lf. longibasidius & Maba \& Verbeken & Maba et al. (2015b) & Afrotropics \\
\hline 115 & Lf. longipes & (Verbeken) Verbeken & Verbeken (1996a) & Afrotropics \\
\hline 122 & Lf. luteopus & (Verbeken) Verbeken & Verbeken (1995) & Afrotropics \\
\hline 123 & Lf. madagascariensis & (Verbeken \& Buyck) Buyck & Buyck et al. (2007) & Afrotropics \\
\hline 124 & Lf. maenamensis & K. Das, D. Chakr. \& Buyck & Das et al. (2017) & Asia \\
\hline 125 & Lf. mamorensis & (Rick) Silva-Filho \& Wartchow & Singer et al. (1983) & Neotropics \\
\hline 126 & Lf. marielleae & J. Duque \& M.A. Neves & Duque Barbosa et al. (2020) & Neotropics \\
\hline 127 & Lf. marmoratus & Delgat & Delgat et al. (2020) & Neotropics \\
\hline 128 & Lf. medusae & (Verbeken) Verbeken & Verbeken (1995) & Afrotropics \\
\hline 129 & Lf. melleus & Maba & Maba et al. (2015b) & Afrotropics \\
\hline 130 & Lf. membranaceus & Maba & Maba et al. (2015a) & Afrotropics \\
\hline 131 & Lf. mexicanus & Montoya, Caro, Bandala \& Ramos & Montoya et al. (2019) & Neotropics \\
\hline 132 & Lf. midnapurensis & S. Paloi \& K. Acharya & Phookamsak et al. (2019) & Asia \\
\hline 133 & Lf. mordax & (Thiers) Delgat & Thiers (1957) & Nearctic \\
\hline 134 & Lf. multiceps & (S.L. Miller, Aime \& TW Henkel) De Crop & Miller et al. (2002) & Neotropics \\
\hline 135 & Lf. murinipes & (Pegler) De Crop & Pegler \& Fiard (1979) & Neotropics \\
\hline 136 & Lf. nebulosus & (Pegler) De Crop & Pegler \& Fiard (1979) & Neotropics \\
\hline 137 & Lf. neotropicus & (Singer) Nuytinck & Singer (1952) & Neotropics \\
\hline 138 & Lf. neuhoffii & (Hesler \& A.H. Sm.) De Crop & Hesler \& Smith (1979) & Nearctic \\
\hline 139 & Lf. nodosicystidiosus & (Verbeken \& Buyck) Buyck & Buyck et al. (2007) & Afrotropics \\
\hline
\end{tabular}


Table 1. (Continued).

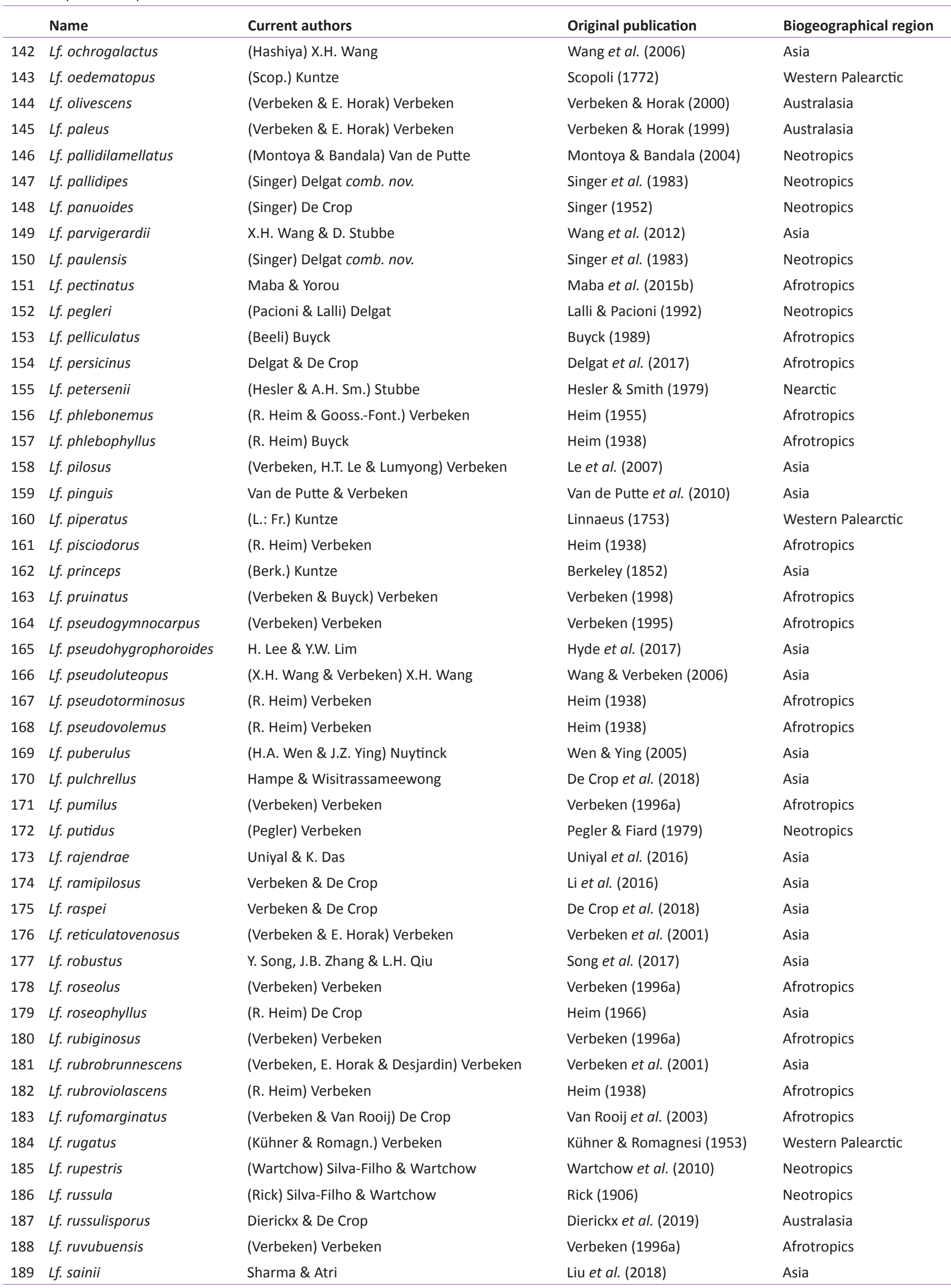


Table 1. (Continued).

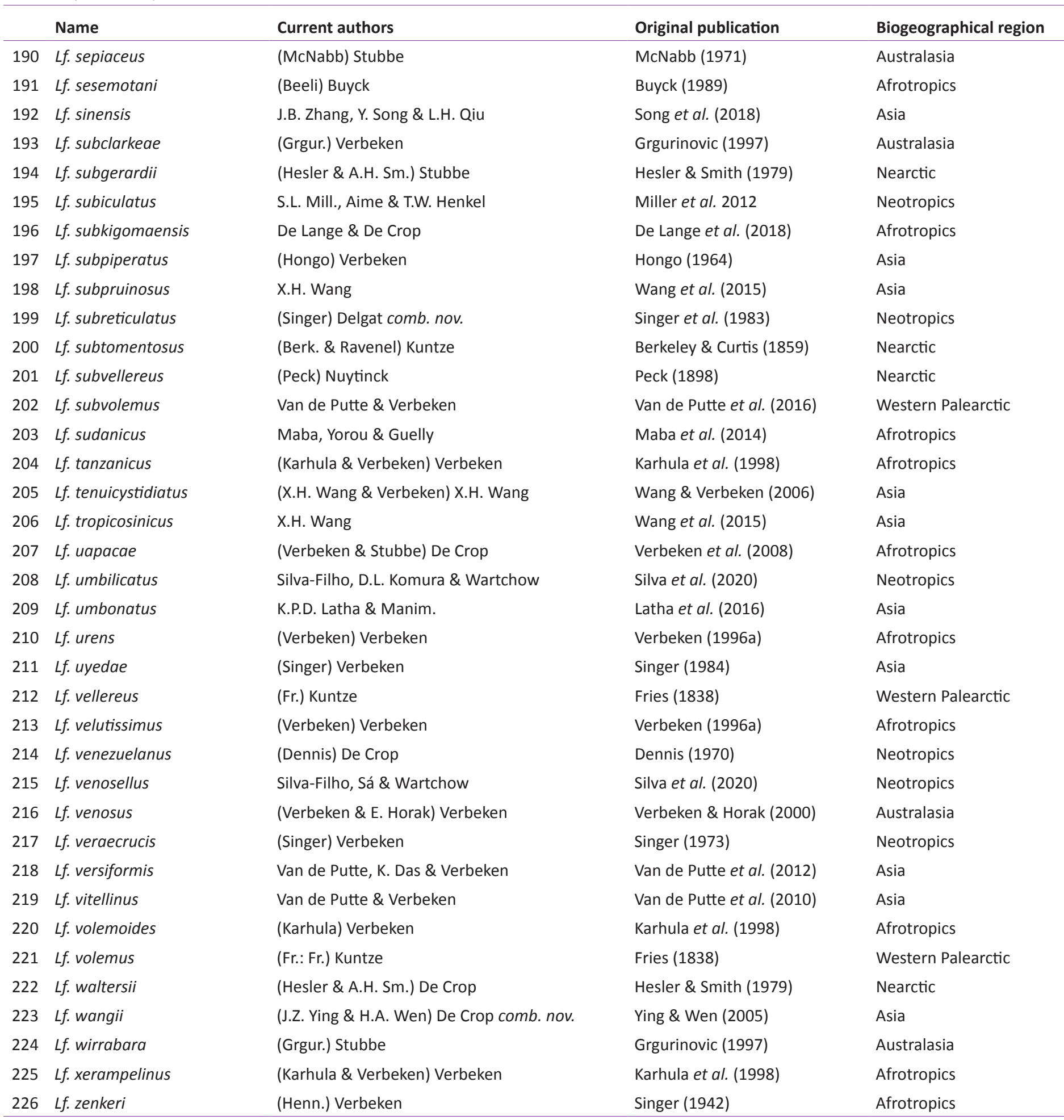

Together with Russula, Lactifluus appears to be one of the most dominant ectomycorrhizal genera in the tropics (Tedersoo et al. 2010b, 2011). Host plants for Lactifluus are leguminous trees (Fabaceae), members of the Dipterocarpaceae and the Fagaceae, together with genera from several other families. European and North American Lactifluus species are mainly associated with trees of Betulaceae (e.g. Betula, Carpinus, Corylus), Fagaceae (e.g. Castanea, Fagus, Quercus), Pinaceae (e.g. Abies, Picea, Pinus), and Cistaceae (e.g. Cistus, Halimium) (Hesler \& Smith 1979, Heilmann-Clausen et al. 1998, Comandini et al. 2006, Van de Putte 2012, Leonardi et al. 2016, Leonardi et al. 2020).
In Asia, Lactifluus species mainly occur with Dipterocarpaceae (e.g. Dipterocarpus, Shorea) and Fagaceae (e.g. Castanopsis, Lithocarpus) (Le 2007, Van de Putte 2012). In sub-Saharan Africa, Lactifluus species often grow with Dipterocarpaceae (e.g. Monotes), Fabaceae (e.g. Afzelia, Berlinia, Brachystegia, Gilbertiodendron, Isoberlinia, Julbernardia), and Phyllanthaceae (e.g. Uapaca) (Verbeken \& Walleyn 2010). In Central and South America, Lactifluus species grow with Fabaceae (e.g. Dicymbe), Fagaceae (e.g. Quercus), Nyctaginaceae (e.g. Neea, Guapira), and Polygonaceae (e.g. Coccoloba) (Tedersoo et al. 2010c). In Australasia, Lactifluus species are mainly associated 

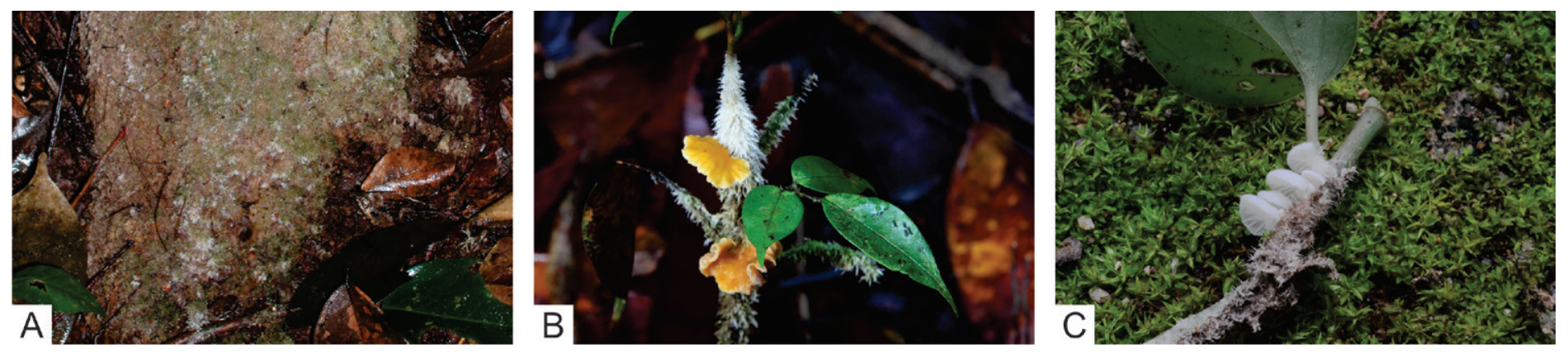

Fig. 6. Lactifluus species growing on trees or plant seedlings. A. Subiculum of Lf. brunellus on the stem of a tree. B. Lf. multiceps (TH 9807). C. Lf. raspei (EDC 14-517) [Photographs by T. Henkel (A), T. Elliot (B) and E. De Crop (C)].

with Myrtaceae (e.g. Eucalyptus and Leptospermum), and Nothofagaceae (e.g. Nothofagus) (McNabb 1971).

Present data suggest that especially generalists occur in Lactifluus, in contrast to Lactarius and Russula where many host specific species are known. It is hard to draw conclusions concerning hosts generalism or specialism in Lactifluus, as studies proving the mycorrhizal association are scarce, but for most Lactifluus species multiple host trees are suggested. Lactifluus volemus, for example, has a broad host range and is known to occur with hosts from both Fagaceae and Pinaceae (Van de Putte et al. 2016). The European Lf. rugatus, that was thought to grow solely with Quercus, is now also known to grow with Cistus in Mediterranean areas (Brotzu 1998, Comandini et al. 2006, Leonardi et al. 2016). The few species that appear to be host specific are so far only known from a few records, such as $L f$. madagascariensis that is only known to occur with Uapaca louvellii in Madagascar (Buyck et al. 2007), Lf. corbula found both in the Democratic Republic of Congo and Cameroon in monodominant Gilbertiodendron dewevrei plots (Henkel, pers. comm.), or Lf. coccolobae which is only known from Coccoloba uvifera in the sand dunes of the Antilles (Miller et al. 2000).

For most Lactifluus species, the exact ECM connection generally remains undetermined. Ecological characteristics are not commonly recorded for every collection during field work, and it is hard to find out which tree a fungal species grows with in mixed forests. Common techniques to detect the host tree in mixed forests are labour-intensive and expensive, since ectomycorrhizal roots have to be excavated, both fungus and plant need to be sequenced, identified, and herbarium material needs to be collected [e.g. in the study of Osmundson et al. (2007)].

\section{Phylogeny and molecular diversity}

In 2017, De Crop et al. (2017) performed a global study of the genus Lactifluus, which resulted in a new infrageneric classification of the genus. Originally the genus was divided in 6 subgenera, 13 sections and three unclassified species, but De Crop et al. (2017) inferred that the genus could be divided into four subgenera: $L f$. subg. Gymnocarpi, Lf. subg. Lactariopsis, Lf. subg. Lactifluus, and Lf. subg. Pseudogymnocarpi (Fig. 7). Each subgenus was further divided into four or more sections, together with undescribed clades and species on isolated positions.

The majority of species was combined into Lactifluus in a series of specific papers (Verbeken et al. 2011, 2012, Stubbe et al. 2012b), other species were combined in Lactifluus as part of larger studies (De Crop et al. 2017, Delgat et al. 2019, 2020), and the remaining species are combined here (see Taxonomy). Table
1 further gives an overview of the currently described species and the subgeneric classification of all Lactifluus species is given in Supplementary Table S1.

The occurrence of several species complexes and species on long and isolated branches reflects the large genetic diversity as was earlier described by Verbeken \& Nuytinck (2013). Several species complexes have been intensively studied and have revealed an enormous diversity. In the complex around Lf. volemus, Van de Putte et al. (2010, 2012, 2016) applied phylogenetic species recognition and discovered about 45 different clades within this group. Some of them could be morphologically distinguished and were described as new species. Others remain cryptic since no morphological differences were found. Stubbe et al. (2010, 2012a) examined the group around $L f$. gerardii. At the start of this study, only a handful of species were known, while at the end, more than 30 clades were discovered, of which about two-third are morphologically identifiable species. De Crop et al. (2014) studied the complex of Lf. sect. Piperati. They found 10-20 putative species worldwide, most of them morphological look-a-likes. Recently, Delgat et al. (2019) studied the complex of $L f$. sect. Albati and reported 29 species, which had previously been identified as only a handful of species based on morphology. These four former species complexes contain species from a wide geographic range (Asia, Europe, Australasia, and North America), from the temperate regions to the tropics. However, no representatives in South America's eastern side of the Andes or sub-Saharan Africa are known. Apart from these four species complexes, several other species are assumed to be part of species complexes. These occur on a somewhat smaller scale (one continent). For example, within the African Lf. gymnocarpoides, Lf. pumilus and $L f$. longisporus all have similar morphological characteristics and are hard to distinguish in the field. In the Neotropics, the species $L f$. annulifer and $L f$. venezuelanus are assumed to be part of a species complex (L. sect. Neotropicus). In Australasia, Lf. clarkeae, Lf. flocktonae and Lf. subclarkeae are morphologically rather similar and together with some undescribed clades, they presumably belong to a species complex (unpubl. res.).

Juxtaposed to the species complexes, several Lactifluus species occur on long branches and have isolated positions in the phylogenetic tree; these include $L f$. ambicystidiatus from China (Wang et al. 2015), Lf. aurantiifolius from tropical Africa (Verbeken 1996a, Buyck et al. 2007), Lf. cocosmus from Togo (Van de Putte et al. 2009), Lf. chrysocarpus from Vietnam (Morozova et al. 2013), and Lf. foetens from Benin and Togo (Van Rooij et al. 2003, De Crop et al. 2016), and Lf. russula from Brazil (Delgat, unpubl. res.). 


\section{Former, traditional classification:}

Lf. subg. Lactariopsis
Lf. subg. Russulopsis
Lf. subg. Edules
Lf. subg. Lactifluus
Lf. subg. Gerardii
Lf. subg. Piperati
Unclassified

\section{Biogeographical regions:}

Afrotropics

Asia

Australasia

Neotropics

Nearctic

Western Palearctic

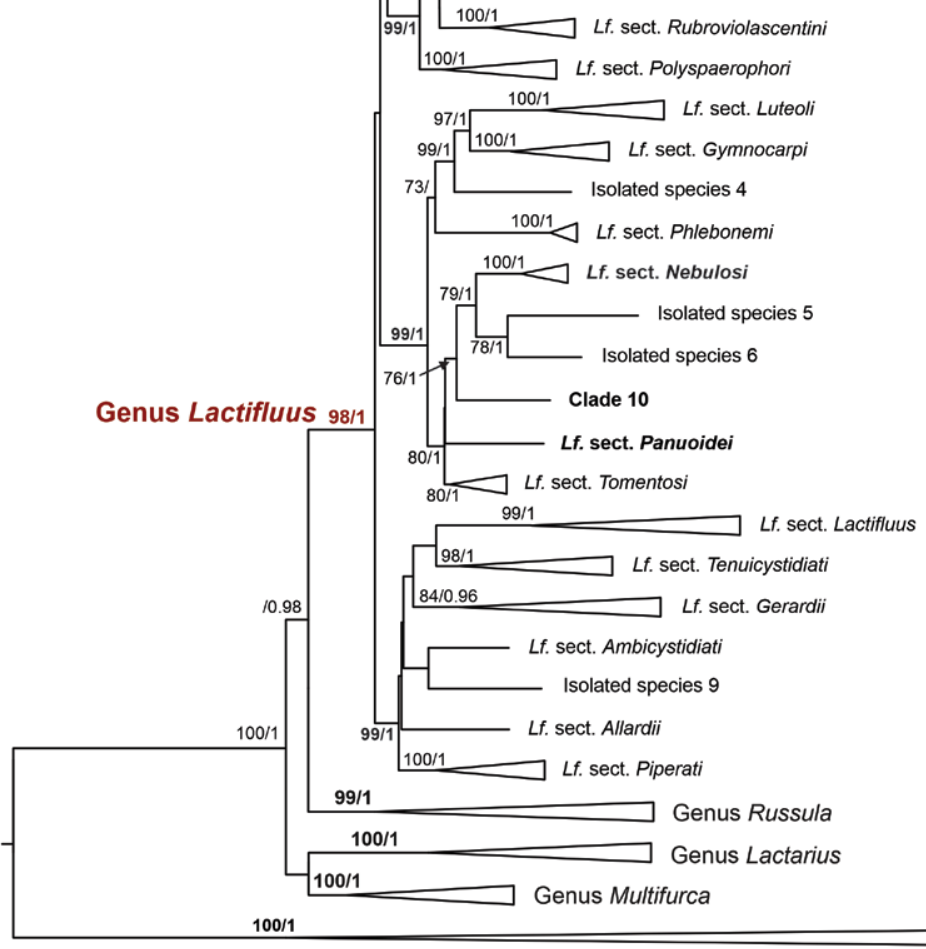

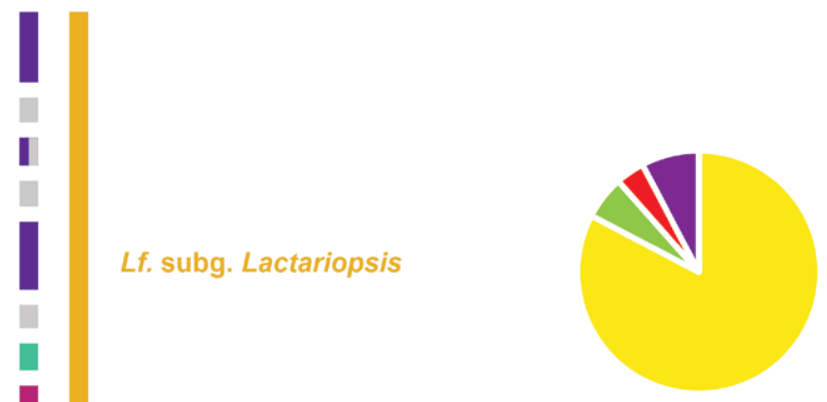

Lf. subg. Pseudogymnocarpi

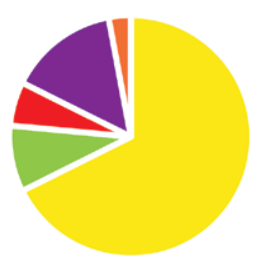

Lf. subg. Gymnocarpi

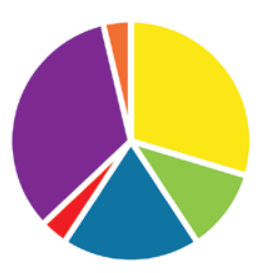

Lf. subg. Lactifluus

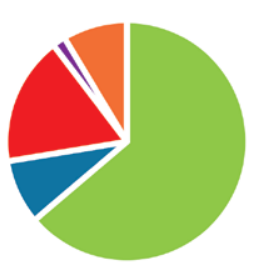

Fig. 7. Overview Maximum Likelihood tree of the genus Lactifluus, based on concatenated ITS, LSU, RPB2 and RPB1 sequence data, adapted from De Crop et al. (2017). The first column of colour bars represents the former, traditional classification. The second column represents the current classification. Pie charts represent the biogeographical regions in which species of each subgenus occur. Maximum Likelihood bootstrap values $>70 \%$ and Bayesian Inference posterior probabilities $>0.95$ are shown. Clade names in bold are names that changed since the publication of De Crop et al. (2017).

\section{Taxonomy}

\section{New combinations}

Eight species, originally described as Lactarius, need to be recombined in the genus Lactifluus.

Lactifluus adustus (Rick) Delgat, comb. nov. MycoBank MB832778.

Basionym: Lactarius adustus Rick, Lilloa 2: 304. 1938.

Lactifluus echinatus (Thiers) De Crop, comb. nov. MycoBank MB832779.

Basionym: Lactarius echinatus Thiers, Mycologia 49: 716. 1957.
Lactifluus epitheliosus (Buyck \& Courtec.) Delgat, comb. nov. MycoBank MB832780.

Basionym: Lactarius epitheliosus Buyck \& Courtec., Mycologia Helvetica 4: 211. 1991.

Lactifluus ignifluus (Vrinda \& C. K. Pradeep) De Crop, comb. nov. MycoBank MB838409.

Basionym: Lactarius ignifluus Vrinda \& C. K. Pradeep, Persoonia 18: 129. 2002.

Lactifluus pallidipes (Singer) Delgat, comb. nov. MycoBank MB832781.

Basionym: Lactarius pallidipes Singer, Beih. Nova Hedwigia 77: 299. 1983. 
Lactifluus paulensis (Singer) Delgat, comb. nov. MycoBank MB832782.

Basionym: Lactarius paulensis Singer, Beih. Nova Hedwigia 77: 305. 1983.

Lactifluus subreticulatus (Singer) Delgat, comb. nov. MycoBank MB832783.

Basionym: Lactarius subreticulatus Singer, Beih. Nova Hedwigia 77: 314. 1983.

Lactifluus wangii (J.Z. Ying \& H.A. Wen) De Crop, comb. nov. MycoBank MB838408.

Basionym: Lactarius wangii J.Z. Ying \& H.A. Wen, Mycosystema 24: 156. 2005.

\section{Excluded names}

Lactarius subpallidipes appears to be a Russula species, for which a new combination is proposed.

\section{Russula subpallidipes (Singer) Delgat, comb. nov. MycoBank MB832784.}

Basionym: Lactarius subpallidipes Singer, Beih. Nova Hedwigia 77: 298. 1983.

\section{Uncertain species/genus status}

From one species, Lactarius steffenii, the type material is apparently lost, and this makes it difficult to assess to which milkcap genus this Brazilian species belongs (Silva-Filho \& Wartchow 2019).

\section{Belowground diversity}

Lactifluus species have been recovered from soil samples in several studies. In the recently published public database GlobalFungi (Vetrovsky et al. 2020, accessed on 28/07/2020) Lactifluus OTUs were found in 343 of the 20009 sampled sites worldwide (in 498 samples when singletons, i.e. OTU abundance $=1$, are included). On a global scale, the study of Tedersoo et al. (2014) have recovered Lactifluus OTU's from all continents. Other studies concentrate on a specific region within a country (e.g. Tian et al. 2017) or focus on a continent (e.g. Bissett et al. 2016).

Preliminary results (see supplementary Tables S2-S4) of the data (singletons excluded) suggest that these metabarcoding data recovered 18 possible new Lactifluus species. Only $23.8 \%$ of the described species available in our dataset were recovered. If we consider both described species and species that are undescribed but known by our research group, only $16.6 \%$ of the species were found. These low numbers are mainly due to an undersampling of the main distribution areas of Lactifluus, i.e. (sub)tropical Africa, Southeast Asia and South America, for which respectively only $22.7 \%, 7.9 \%$ and $6.8 \%$ of the known species were found in soil samples. Furthermore, in order to find Lactifluus, samples need to be taken in proximity of ECM trees, which was mostly not the case.

Comparing the results between continents, different patterns emerge. Twenty-eight of the 240 sampled sites in Africa contained Lactifluus OTUs. Those 28 samples were taken in five regions in sub-Saharan Africa, all with a history of Lactifluus research. Those regions are largely covered by ECM vegetation. Lactifluus is one of the dominant ECM fungal groups present in those vegetation types and this is reflected in the results. In the 28 sampling sites, $22.7 \%$ of the known and described African species and ten possible new lineages were retrieved. These results suggest that with new regions explored, there might still be many new Lactifluus species to be found in sub-Saharan Africa.

The Asian samples were taken all over the continent, however, not always in ECM forest. Thus from the almost 3000 sampled sites, Lactifluus was found in only 25 sampling sites. This includes $7.9 \%$ of the known or described Asian species and three possible new lineages. This is only a fraction of the currently known Asian diversity.

Due to the BASE project (Bissett et al. 2016), the Australasian region is rather well sampled. Although Lactifluus OTUs were found in only $6 \%$ of the sampled sites, $54.5 \%$ of the known or described Australasian species were found. Ten known species were not retrieved in the soil samples and two more possible new lineages were found.

In absolute numbers, Europe is the best sampled region. However, samples were mainly taken for studies with a focus on specific regions, not covering the whole continent and not necessarily taken in proximity of ECM trees. This is reflected in the results for Lactifluus. Less than $1 \%$ of the sampling sites contains Lactifluus OTUs, and of the nine known and described species, only four were retrieved. Due to the lack of sampling sites in Southern Europe, none of the more Mediterranean species was found. As the European Lactifluus species have been studied in great detail (Heilmann-Clausen et al. 1998, Basso 1999, De Crop et al. 2014, Leonardi et al. 2016, Van de Putte et al. 2016, Delgat et al. 2019, Dierickx et al. 2019b), we did not expect new lineages to emerge, which was indeed the case.

North America also contains a lot of sampled sites, however, again constricted to certain areas. Lactifluus OTUs were found in only $1.4 \%$ of the samples, $27 \%$ of the known species were retrieved in the soil samples, and two possible new lineages were found.

In Central and South America, ECM trees are mostly scattered throughout the forests, which makes it difficult to detect ECM fungi from soil samples. From the 33 sampling sites in which Lactifluus was found, the majority was taken in the forests of Western Guyana where monodominant forests of the ectomycorrhizal Dicymbe corymbosa occur and where Russulaceae have been the focus of a series of studies (Henkel et al. 2000, 2012, Miller et al. 2002, 2012). However, only $6.8 \%$ of the known or described species was found, and those found were thus only species known to occur in those Dicymbe forests. Only one possible new lineage was found.

\section{Macromorphology}

Despite the existence of species complexes, in which morphological diversity is rather limited, the genus Lactifluus generally shows a large diversity of macromorphological characters (Fig. 8), which can often be used for species delimitation.

A striking first character is the sporocarp type and size. Currently, three different sporocarp types are known in Lactifluus: the agaricoid type (i.e. with cap, gills and centrally attached stipe, e.g. Fig. 8A), the pleurotoid type (i.e. with cap, gills and laterally attached stipe, e.g. Fig. $8 \mathrm{~L}$ ), and the sequestrate sporocarp type (Lebel et al. 2016). Sporocarps of Lactifluus species range from miniscule sporocarps, such as in Lf. igniculus (pileus $5-16 \mathrm{~mm}$ diam), to large basidiocarps, such as in $L f$. vellereus (pileus $50-$ $300 \mathrm{~mm}$ diam.). Most sporocarps grow directly on soil, but tiny 
agaricoid and pleurotoid species may often grow on a subiculum (Fig. 6), which is an interwoven network of thick-walled hyphae from which sporocarps arise. This subiculum grows on saplings, roots, stems, soil or rocks, and can be intermixed with bryophyte growth and subtended by ectomycorrhizal rootlets. It can be small to very extensive, e.g. the subiculum of $L f$. multiceps was recorded to stretch out over $15 \mathrm{~m}$ (Miller et al. 2002).

Within the Russulaceae, the genera Lactifluus and Russula are known to contain species with a secondary velum. In Lactifluus, this velum can be present as an annulus around the stipe or as velar remnants on the pileus edge (Fig. 9). The annulus is fibrous, membranous, thin to almost invisible and not mobile, unlike in some Russula species with a mobile annulus which often sticks to the growing cap (Fig. 3C). Species with a secondary velum, together with their closest relatives, are characterised by an involute pileus margin when young. This involute pileus margin can make contact with the stipitipellis and protects the developing lamellae (Heim 1937).

The pileus shape of Lactifluus species varies between applanate, planoconvex, concave, infundibuliform or deeply infundibuliform. Pileus colours range from white, yellow, orange, red to brownish colours. Pileus surfaces range from smooth caps to chamois-leather-like to velvety or woolly (Fig. 10). Some species, especially from $L f$. sect. Albati are known for their woolly pileus surface and their local names often refer to this aspect (e.g. Lactifluus vellereus in Dutch: schaapje, in English: fleecy milkcap, in German: Wollige Milchling, Mildmilchender Wollschwamm or Samtiger Milchling, in Spanish: lactario aterciopelado). The pileus margin is often concentrically wrinkled near the edge and can be grooved or involute. The pileus edge is either entire, crenulate or eroded. Stipe colours and surface mainly resemble those of the pileus but are often slightly paler or less felted. The stipe is generally centrally attached and often tapering downwards or curved near the base.

Lamellae of Lactifluus species are mostly slightly paler than the pileus, except in some species, e.g. Lf. aurantiifolius with dark yellow-orange lamellae. Lamellae may be thin, almost paper-like, such as in Lf. pelliculatus; or thick and brittle, such as in $L f$. rubroviolascens. They may be very broad, as in $L f$. sesemotani or narrow, as in $L f$. inversus. Some are distant, as in Lf. distantifolius, or very crowded, as in Lf. phlebophyllus (Fig. 11). The attachment to the stipe varies from adnate, adnate with a decurrent tooth to decurrent. Generally, the lamella edge is entire and concolourous with the rest of the lamellae. However in some species, like $L f$. bicolor, the lamella edge is concolourous with the pileus or stipe. In almost all Lactifluus species, lamellulae (I) are present between the lamellae (L). These lamellulae often occur in a pattern: $L-I-L$ or $L-I_{s}-\mid-I_{s}-L$, with $I_{s}$ the smallest lamellula. Various Lactifluus species have bifurcating lamellae, while others have venation patterns on their lamellae. Venation is either transvenose (when veins occur on the lamella surface) or intervenose (when veins occur between lamellae).

As indicated by their name, Lactifluus species, as Lactarius species, exude latex when bruised. Several latex features have been important in species delimitation in both genera. In Lactifluus, latex can be white, coloured, watery or whey-like and some species have latex changing colour (e.g. blue-green, brown or red-black) after contact with air (Fig. 12). In some species, the latex colours the lamellae and context after exposure to air. Species differ in latex abundance or taste. For instance, in Lf. volemus latex is very abundant and in $L f$. piperatus, the latex is very acrid.
The context of Lactifluus species ranges from firm to stuffed, to partly hollow, chambered or hollow (Fig. 13). The context of most species is white or cream-coloured and in some species, the context changes colour after exposure to air. The context is mild or has a very acrid taste, such as in $L f$. acrissimus or $L f$. urens. Some species smell like fish or seafood (Lf. volemus, $L f$. nonpiscis), fruit ( $L f$. edulis, $L f$. aureifolius), or coconut ( $L f$. cocosmus). Some of the typical odours that occur in the genus Lactarius are lacking here, for example the Heteroptera-odour of L. quietus, the odour of curry or camphor of L. camphoratus, or the fenugreek odour of $L$. helvus. The spore print of all Lactifluus species is white but cannot be used explicitly to delimit Lactifluus species.

\section{Micromorphology}

The genus Lactifluus is known for the occurrence of thick-walled elements in many of its species. For terminology concerning these characters we follow Verbeken \& Walleyn (2010).

\section{Structures of the pileipellis and stipitipellis}

The structure of the pileipellis is an important character in this genus and is used to delimit species, sections or subgenera. As pileipellis and stipitipellis structures slightly change during their development (Verbeken \& Walleyn 2010), pellis structures in this study were observed in mature specimens. Drawings were made using tissue taken halfway along the radius of the pileus or halfway up the stipe height.

For the description of the pellis structures, we follow Heilmann-Clausen et al. (1998) and Verbeken \& Walleyn (2010). In Lactifluus, the pileipellis is regularly differentiated from the underlying trama and often consists of two layers, indicated as supra- and subpellis. The most important characters to look at are the presence of thick-walled elements, the presence of isodiametric cells and the orientation of the terminal elements.

Thick-walled elements are present in many Lactifluus species. They may occur as one consistent layer or as scattered hairs in a layer of thin-walled elements. Their presence is indicated with the prefix "lampro" in the name of that pileipellis structure, e.g. lampropalisade.

Many Lactifluus species are characterised by the presence of isodiametric cells, or sphaerocytes, in the subpellis, more rarely in the suprapellis. These are thin- or thick-walled and form one distinct layer or are mixed with cylindrical hyphae.

In case of a distinctly two-layered pileipellis, the suprapellis consists of terminal elements. These are either hair-like elements, hyphae or clavate elements. Their orientation is important in defining the different pellis structures.

The combination of these characters leads to a differentiation between 14 pilei- and stipitipellis types (Fig. 14). Intermediate types sometimes occur.

\section{Pellis entirely composed of filamentous elements, without} isodiametric cells

- Cutis: the suprapellis consists of hyaline, thin-walled hyphae, which lay parallel, pericline or are slightly intermixed. Differentiated terminal elements are mostly lacking, although in some species of $L f$. sect. Russulopsidei, there are dermatocystidia present in this layer.

- Irregular cutis: the suprapellis consists of hyaline, thinwalled hyphae which are irregularly ordered. 

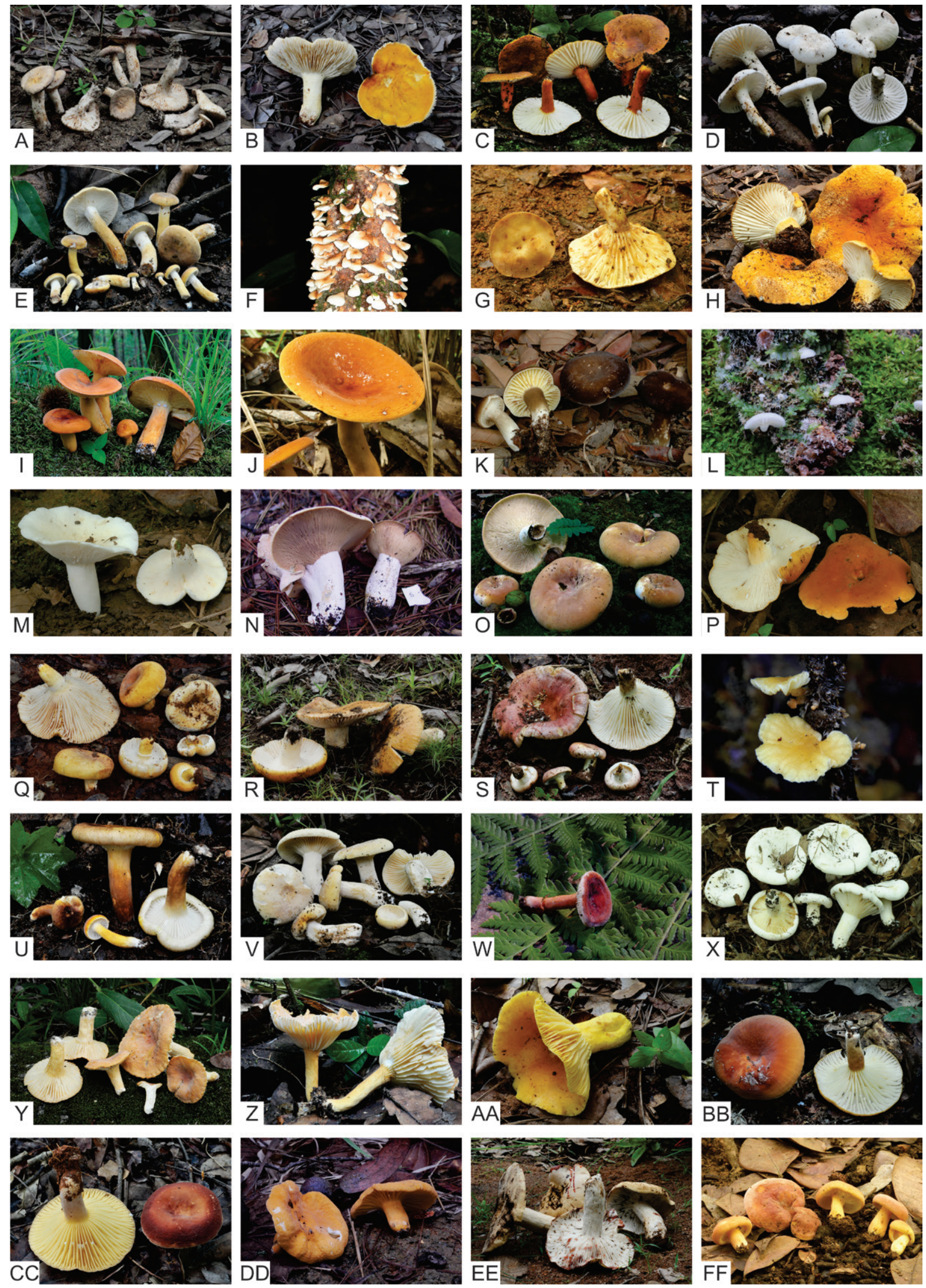

Fig. 8. Overview of different types of Lactifluus sporocarps. Lf. subg. Gymnocarpi: A. Lf. nonpiscis (EDC 14-056). B. Lf. tanzanicus (EDC 11-224). C. Lf. gymnocarpus (EDC 12-047). D. Lf. albomembranaceus (EDC 12-046). E. Lf. cf. phlebonemus (EDC 12-067). F. Lf. panuoides. G. Lf. putidus (LD 15-002). H. Lf. clarkeae (REH 9871). Lf. subg. Lactifluus: I. Lf. volemus. J. Lf. longipilus (KVP 08-005). K. Lf. atrovelutinus (DS 06-003). L. Lf. raspei (EDC 14-517). M. Lf. aff. piperatus (DS 07-467). N. Lf. roseophyllus (JN 2011-076). O. Lf. allardii (C.C. 3.0). P. Lf. aff. tenuicystidiatus (DS 07-465). Lf. subg. Lactariopsis: Q. Lactifluus sp. (EDC 11-068). R. Lactifluus sp. (EDC 14-091). S. Lf. cyanovirescens (EDC 11-021). T. Lf. multiceps (TH 9807). U. Lf. longipes (EDC 14-049). V. Lactifluus sp. (EDC 12-069). W. Lf. roseolus (EDC 14-228). X. Lf. subvellereus (AV 13-025). Lf. subg. Pseudogymnocarpi: Y. Lf. cf. gymnocarpoides (EDC 14-106). Z. Lf. medusae (EDC 12-152). AA. Lf. luteopus (EDC 14-086). BB. Lf. bicapillus (EDC 12-176). CC. Lf. rubiginosus (EDC 11-067). DD. Lf. armeniacus (EDC-501). EE. Lf. denigricans (EDC 14-067). FF. Lf. pegleri (LD 15-014) [Photographs by E. De Crop (A-E,L,Q-S,U-W,Y-EE), T. Henkel (F), L. Delgat (G,FF), R. Halling (H), G. Boerio (I), K. Van de Putte (J), D. Stubbe (K,M,P), J. Nuytinck (N), D. Molter C.C. 3.0 (O), T. Elliot (T) and A. Verbeken (X)]. 

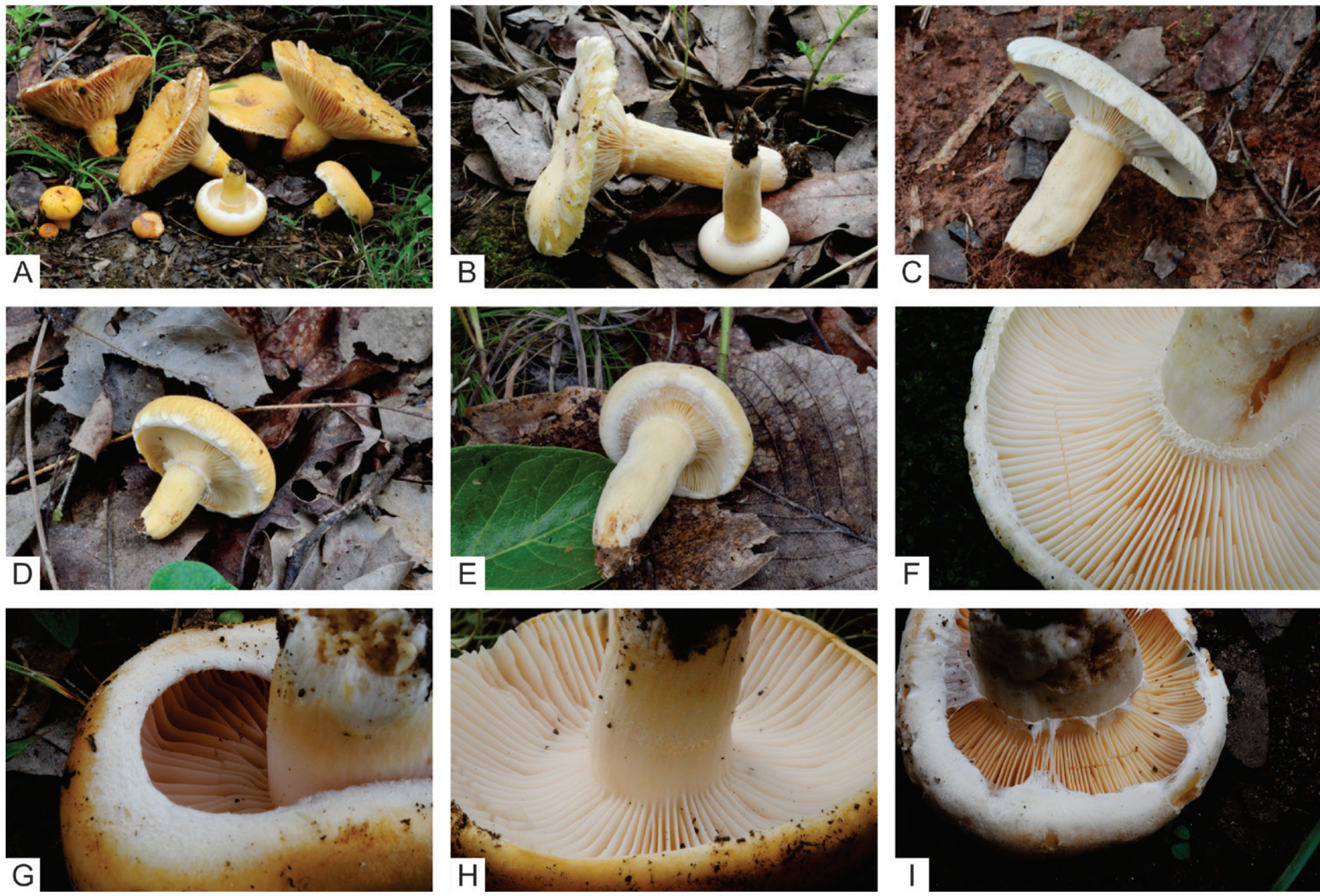

Fig. 9. Overview of different types of velum in unidentified Lactifluus spp. A. EDC 14-060. B. EDC 14-065. C. EDC 11-127. D. EDC 11-144. E. EDC 14-172. F. EDC 14-059. G. EDC 14-146. H. EDC 14-091. I. EDC 14-051. [Photographs by E. De Crop (A-D, F-I) and J. Nuytinck (E)].
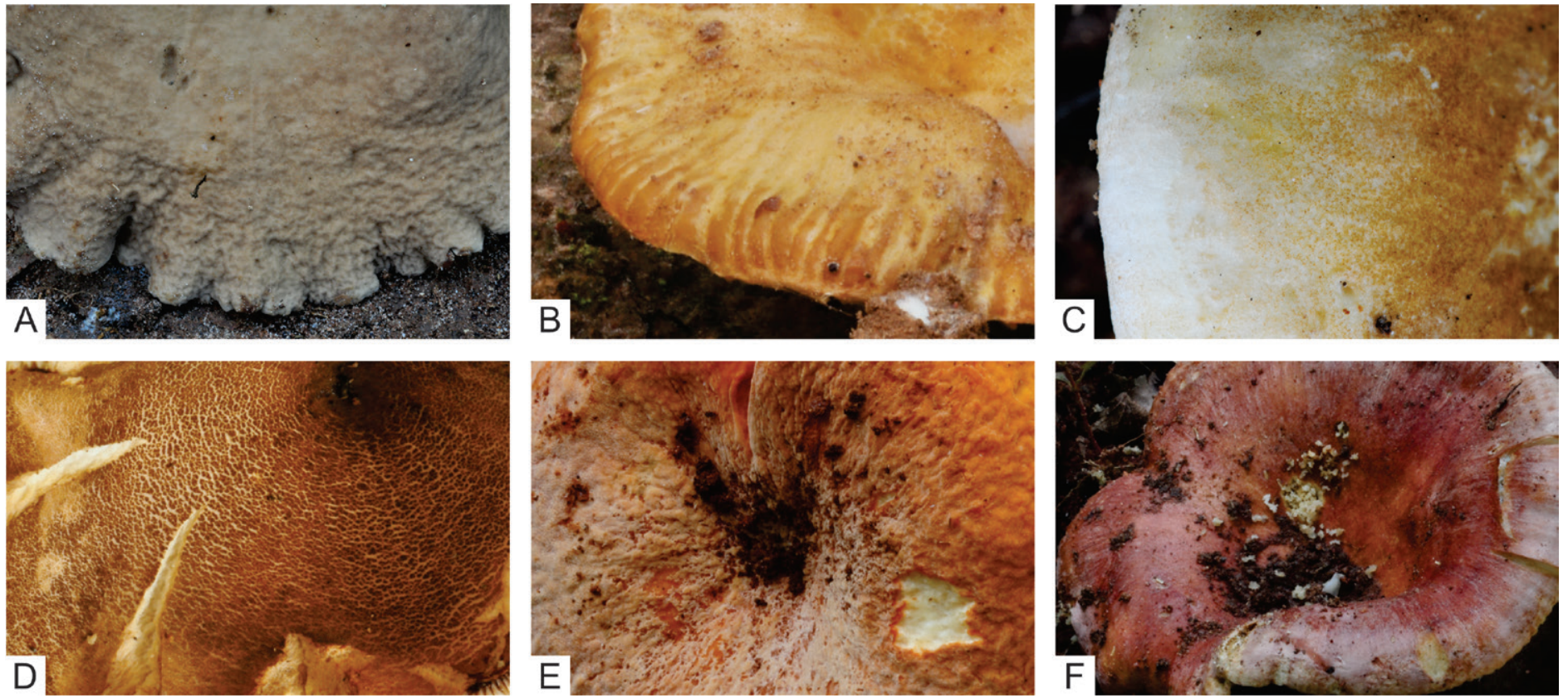

Fig. 10. Overview of different types of pileus surface in Lactifluus. A. Wrinkled and finely felty pileus of Lf. brunnescens (EDC 12-116). B. Sulcate pileus of Lactifluus sp. - Lf. sect. Lactariopsis (EDC 11-084). C. Finely squamulose pileus of $L f$. urens (EDC 14-032). D. Pileus tomentose and cracked into small, felty flocks in Lf. inversus (EDC 12-070). E. Pruinose pileus of Lactifluus sp. (EDC 14-153). F. Smooth and somewhat shiny pileus of Lf. cyanovirescens (EDC 11-021) (Photographs by E. De Crop). 

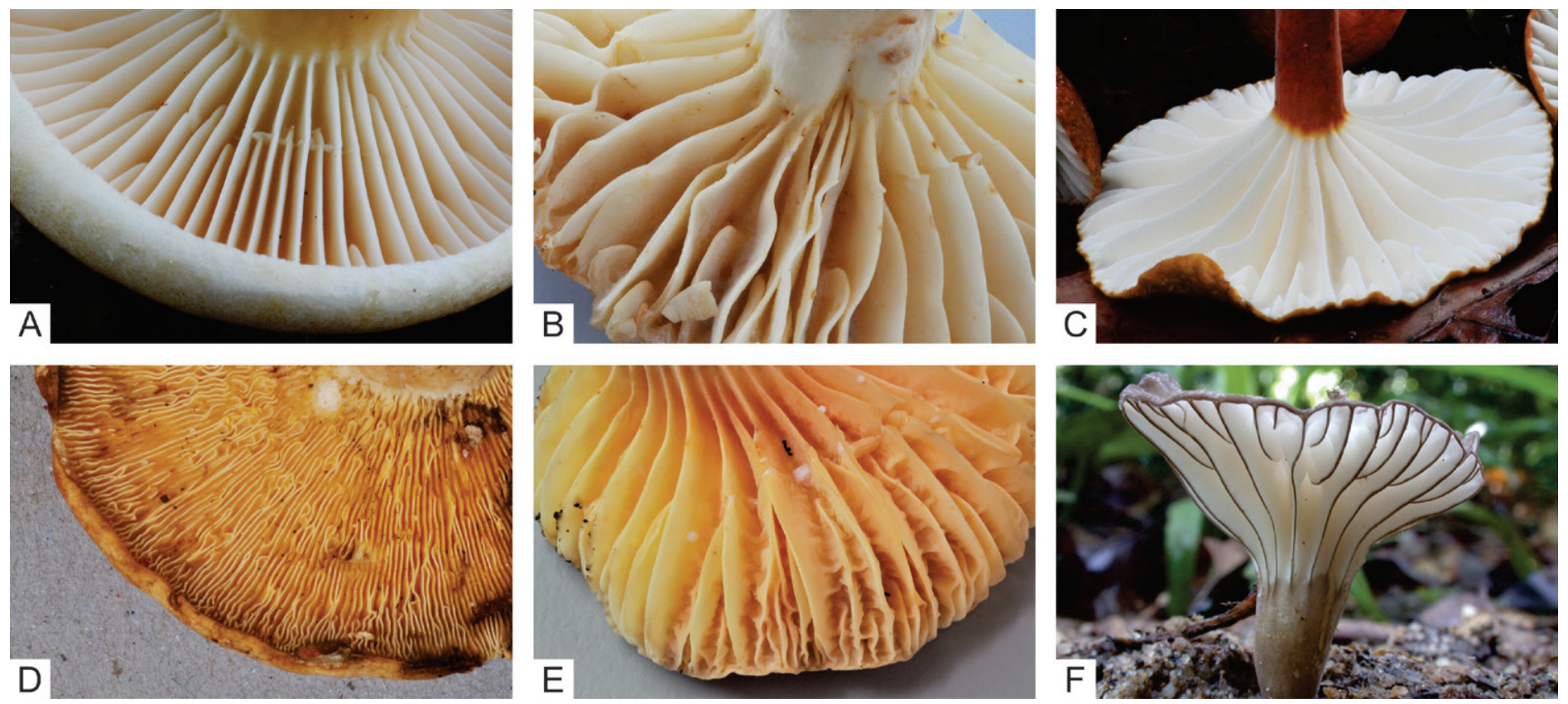

Fig. 11. Overview of different types of lamellae in Lactifluus. A. Thin and paper-like lamellae of $L f$. urens (EDC 14-032). B. Thick and brittle lamellae in Lf. aff. longisporus (EDC 12-199). C. Distant and broad lamellae in Lf. gymnocarpus (EDC 12-055). D. Bifurcating narrow and crowded lamellae in Lf. densifolius (EDC 11-220). E. Lamellae with venation of Lf. persicinus (EDC 12-002). F. Lamellae with coloured edge in Lf. bicolor (DS 06-230) [Photographs by E. De Crop (A-E) and D. Stubbe (F)].
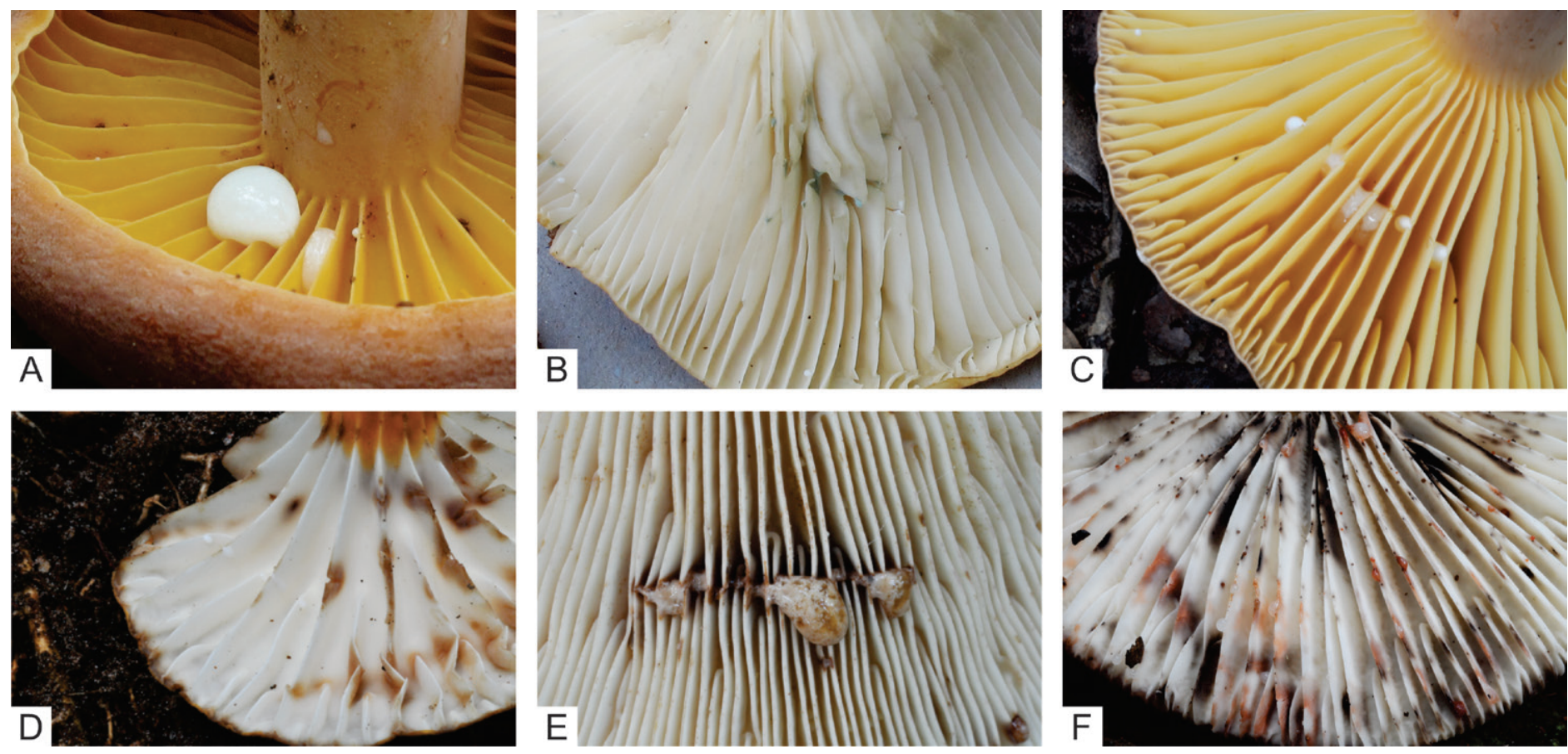

Fig. 12. Overview of different types of latex colourations in Lactifluus. A. Unchanging white latex in Lactifluus sp. (AV 11-089). B. White latex changing greenish in Lf. cyanovirescens (EDC 11-001). C. Unchanging watery white latex in Lf. rubiginosus (EDC 11-067). D. White latex that colours the lamellae brownish in Lf. gymnocarpus (EDC 12-103). E. Brown whey-like latex in Lf. brunnescens (EDC 12-116). F. Watery white latex changing red and later black in Lf. rubroviolascens (EDC 14-384) [Photographs by A. Verbeken (A) and E. De Crop (B-F)].

- Ixocutis: the suprapellis consists of hyaline, thin-walled hyphae which are embedded in a slime layer, which may be produced by hyphae secreting slime or by gelatinized hyphae walls.

- Trichoderm: the suprapellis consists of hyaline, thin-walled hyphae, of which the terminal elements are ascending and lay anticline. These hairs often form dense turfs.
- Lamprotrichoderm: the suprapellis consists of hyaline, thinwalled hyphae, of which the terminal elements are thickwalled, ascending and lay anticline.

- Ixotrichoderm: the suprapellis consists of hyaline, thinwalled hyphae, of which the terminal elements are ascending, lay anticline and are embedded in a slime layer, which may be produced by hyphae secreting slime or by gelatinized hyphae walls. 

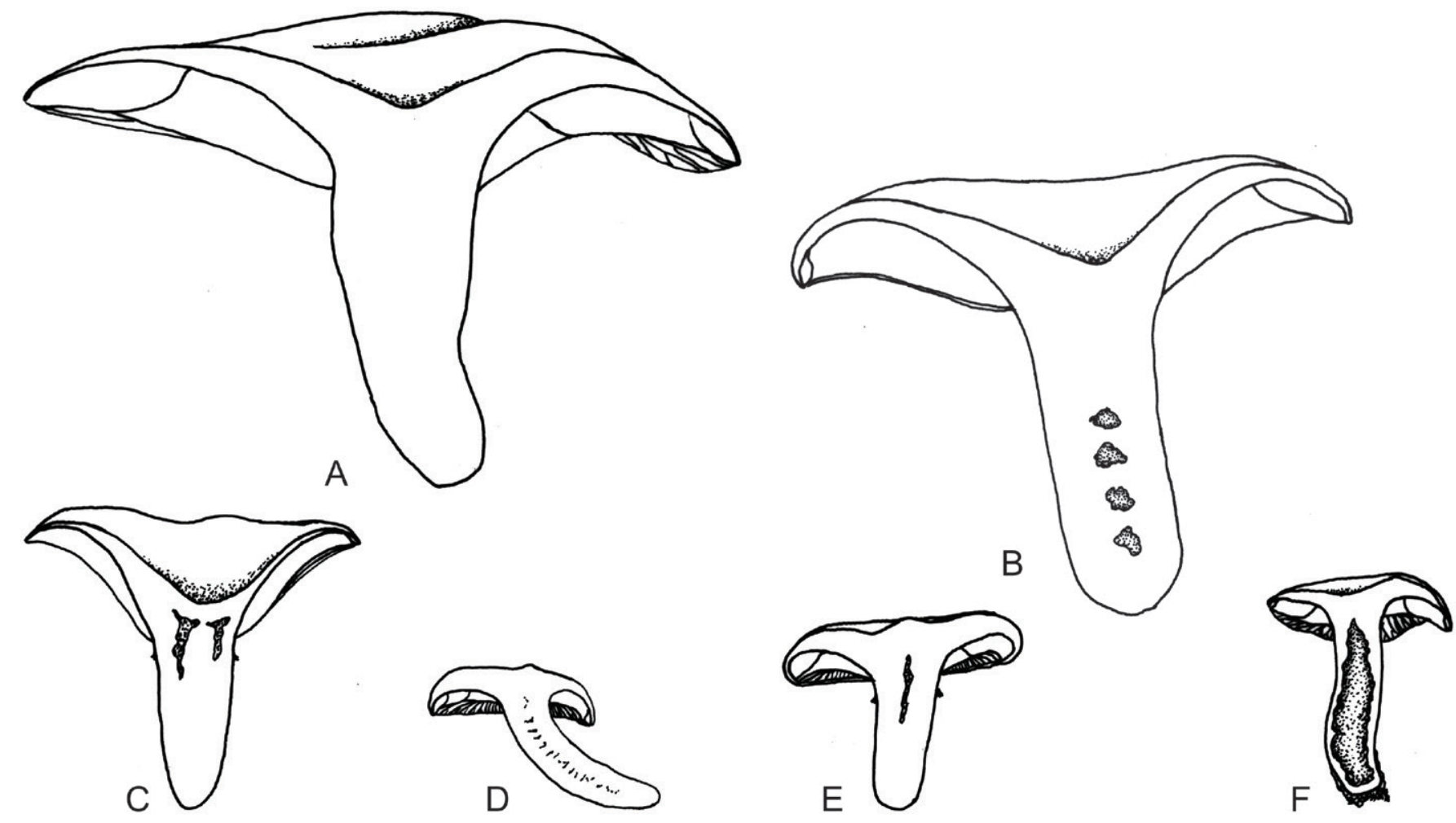

Fig. 13. Overview of different types of context in Lactifluus. A. Firm context in Lf. urens (EDC 14-032). B. Chambered context in Lactifluus sp. (EDC 14061). C. Chambered context in Lactifluus sp. (EDC 14-046). D. Stuffed context in Lactifluus sp. (EDC 14-512). E. Partly hollow context in Lactifluus sp. (EDC 14-038). F. Hollow context in Lf. nonpiscis (EDC 14-056) [Scale bar $=1 \mathrm{~cm}$. Line drawings by E. De Crop].

\section{Pellis with a distinct layer of isodiametric cells}

- Hyphoepithelium: the suprapellis consists of pericline, hyaline and thin-walled hyphae, which lay on a cellular subpellis.

- Palisade: the suprapellis consists of anticline, thin-walled, elongated terminal elements, which lay on a cellular subpellis. The terminal elements are either hair-like or septate.

- Lampropalisade: the suprapellis consists of anticline, thickwalled, elongated terminal elements, which lay on a cellular subpellis.

- Hymeniderm: the suprapellis consists of anticline, thinwalled, short and clavate terminal elements, which lay on an often thin cellular subpellis.

\section{Pellis with isodiametric cells, but never forming a distinct} layer

- Trichopalisade: looks like a trichoderm in which some of the anticline hyphae are inflated or rounded, which gives it a palisade-like impression.

- Lamprotrichopalisade: as a trichopalisade, but with thickwalled terminal elements.

- Mixed trichopalisade: as a trichopalisade, in which some terminal elements are thick-walled.

- Mixed trichopalisade with abundant thick-walled elements: as a trichopalisade, in which the majority of terminal elements are thick-walled.

Dermatocystidia rarely occur in the genus Lactifluus. However, they are present in $L f$. sect. Russulopsidei and $L f$. sect. Piperati, in the upper layer of cutis-like structures or of a hyphoepithelium (Fig. 15).

\section{Hymenial elements}

Basidia and basidioles only slightly differ between closely related species (Fig. 16). Some species have long and slender basidia, such as $L f$. albomembranaceus, while others have small and almost clavate basidia, such as Lactifluus sp. (EDC 14-061; Fig. 16B). Sterigmata can be short, or long and slender. Most basidia have four sterigmata and form four spores. However, several Lactifluus species also have two- or one-spored basidia, such as Lf. bicapillus (EDC 12-071; Fig. 16D). Basidia are measured excluding sterigmata and their width is measured at the broadest place.

The genus Lactifluus displays different cystidium types. Pseudocystidia, which also occur in Lactarius and some Multifurca species, have no septum and are the extremities of lactiferous hyphae (Fig. 17). Their content therefore resembles the content of lactiferous hyphae, which is refringent, dense, oleiferic or needlelike to granular (Verbeken \& Walleyn 2010). In Lactifluus, their abundance and form may vary considerably. In many species of $L f$. subg. Pseudogymnocarpi they are scarce, while in many species of $L$ f. sect. Lactariopsis they are conspicuous and abundant. Pseudocystidia are slender or broad and in some species strongly emergent. Their top is rounded, tapering, moniliform or even forked. Depending on their position on the lamellae, they are called pleuropseudocystidia, when located at the lamella side, or cheilopseudocystidia, when located at the lamella edge.

True pleurocystidia and cheilocystidia also occur. Three different types of true cystidia are known in Lactifluus species (Fig. 18). Lamprocystidia: thick-walled cystidia, which are often very large, frequently emergent to strongly emergent and sometimes septate. Some of the largest lamprocystidia emerge from within 


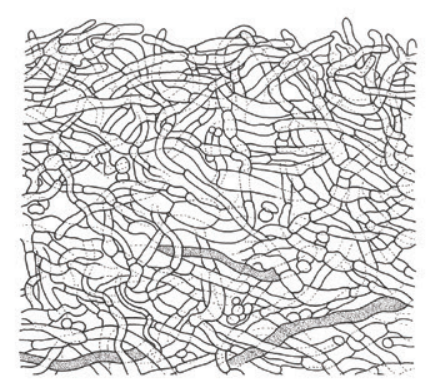

A

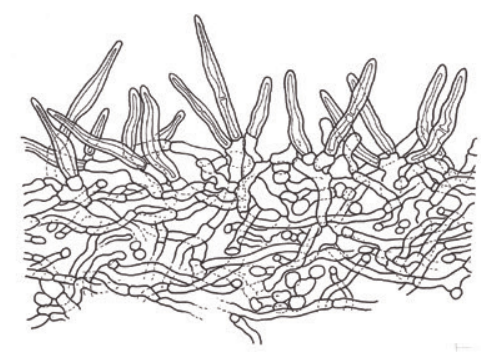

D

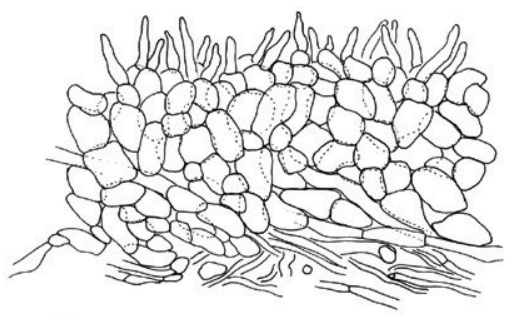

G

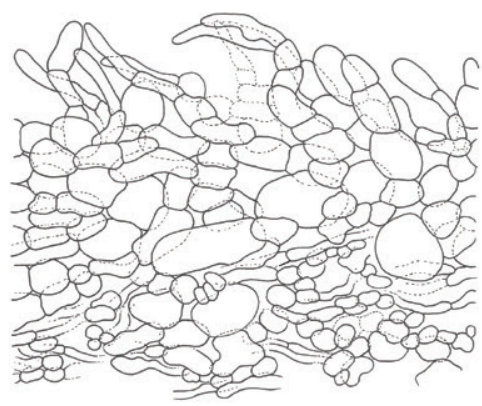

J

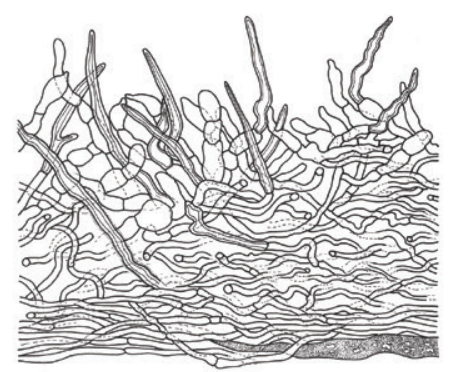

M

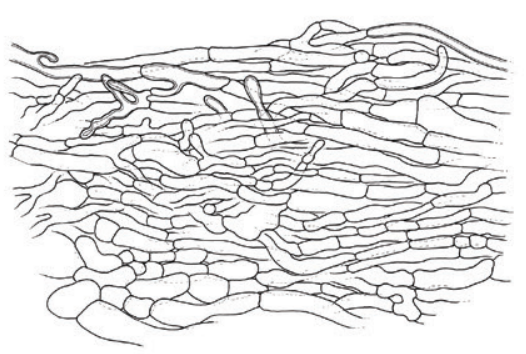

B

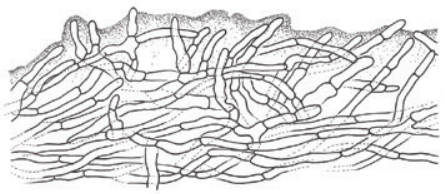

E

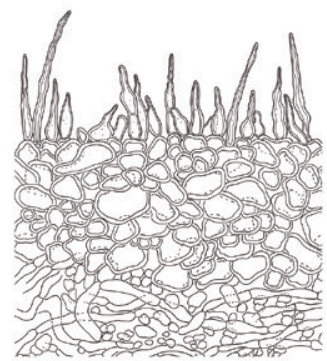

$\mathrm{H}$

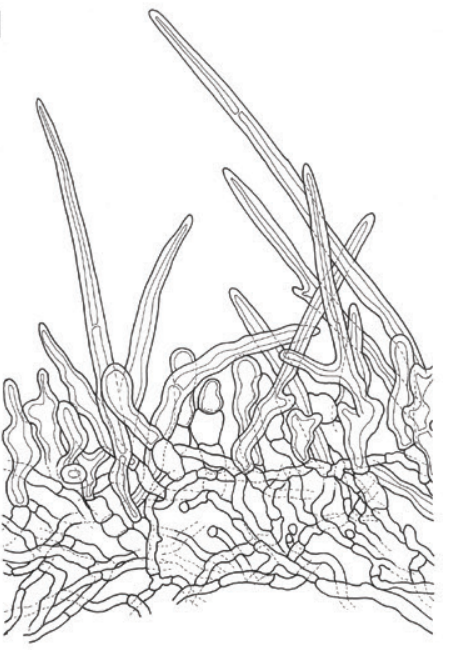

K

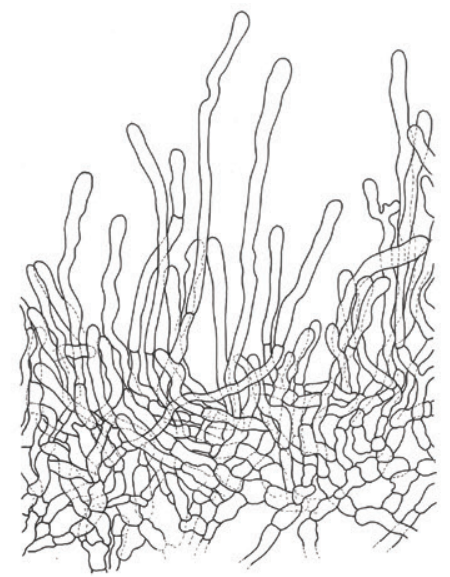

C
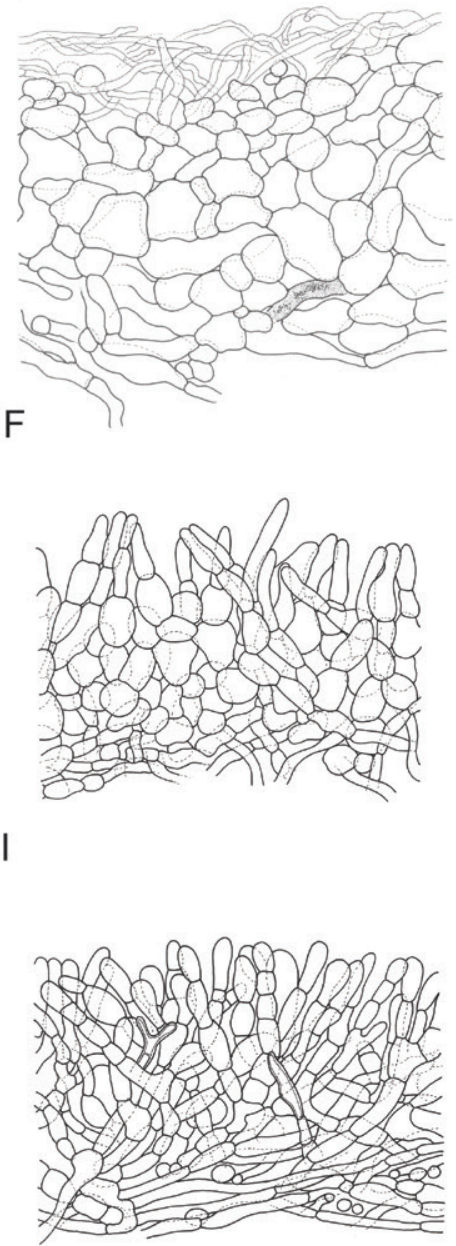

L

Fig. 14. Overview of different pileipellis types found in the genus Lactifluus. A. Cutis in Lf. urens (JR 6002). B. Irregular cutis in Lf. hallingii (FH 18077). C. Trichoderm in Lf. aurantiifolius (AV 94-063). D. Lamprotrichoderm in Lf. pruinatus (BB 3248). E. Ixotrichoderm in Lf. rufomarginatus (ADK 3011). F. Hyphoepithelium in Lf. piperatus (HP 8475). G. Palisade in Lf. atrovelutinus (DS 06-003). H. Lampropalisade in Lf. oedematopus (RW 1228). I. Hymeniderm in Lf. roseolus (AV 94-064). J. Trichopalisade in Lf. xerampelinus (TS 1116). K. Lamprotrichopalisade in Lf. heimii (AV 94-465). L. Mixed trichopalisade in Lf. indusiatus (AV 94-122). M. Mixed trichopalisade abundant thick-walled elements in Lf. sesemotani (GF 143). [Scale bar = 10 $\mu \mathrm{m}$. Line drawings by A. Verbeken (A, C-F, I-M), L. Delgat (B), D. Stubbe (G) and K. Van de Putte (H)]. Adapted from fig. 1 from De Crop et al. (2017). 


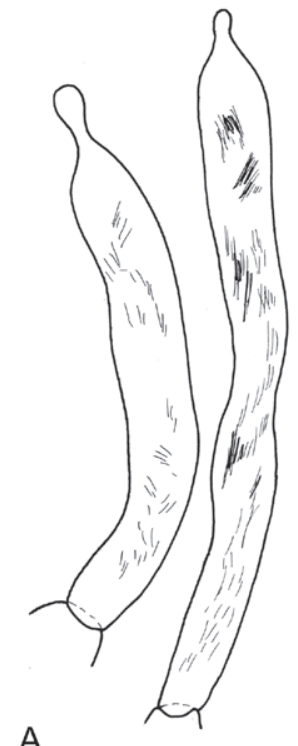

A

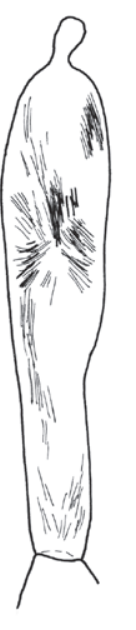

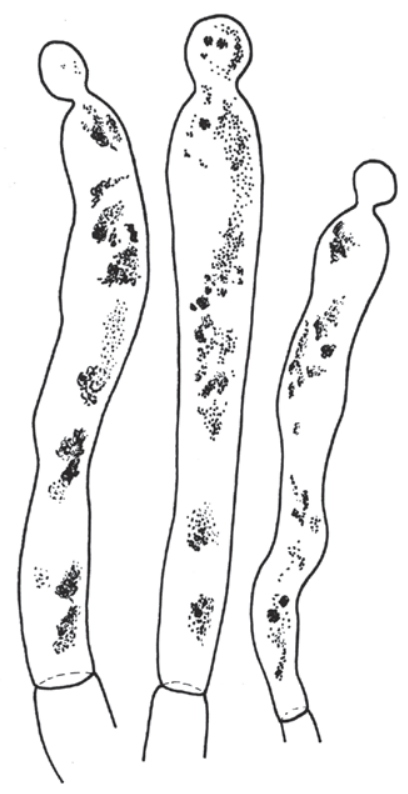

B

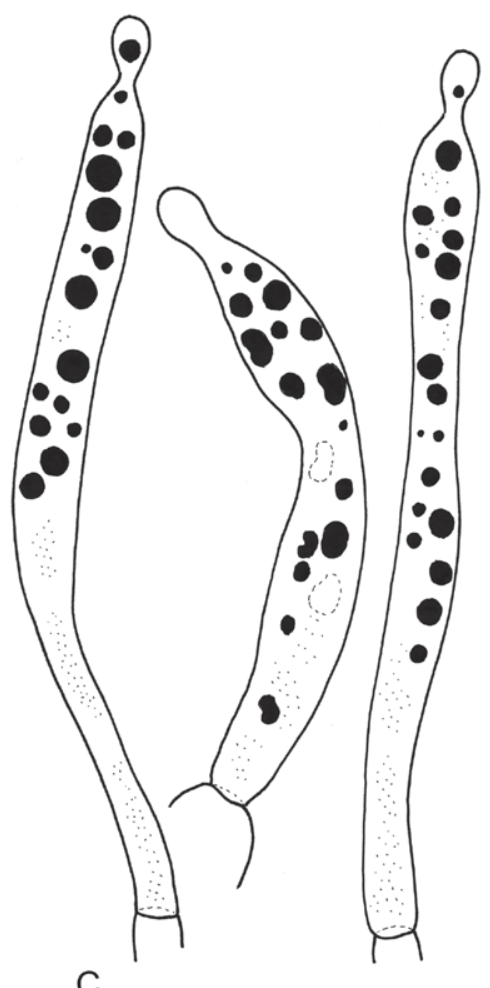

C

Fig. 15. Overview of different types of dermatocystidia found in the genus Lactifluus. A. Lf. ruvubuensis (AV 94-617). B. Lf. longipes (BB 1345). C. Lf. claricolor (R. Heim J18bis) [Scale bar $=10 \mu \mathrm{m}$. Line drawings by A. Verbeken $(A-C)$ ].

A

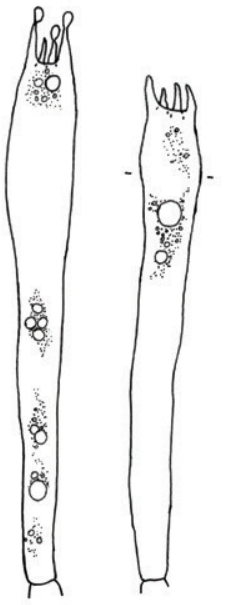

C
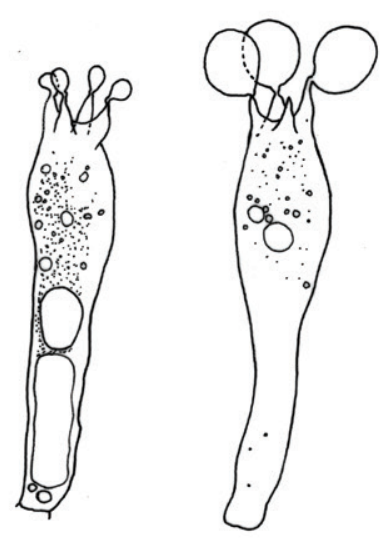

B

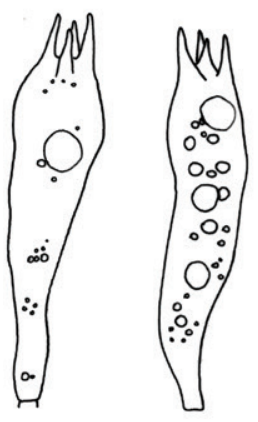

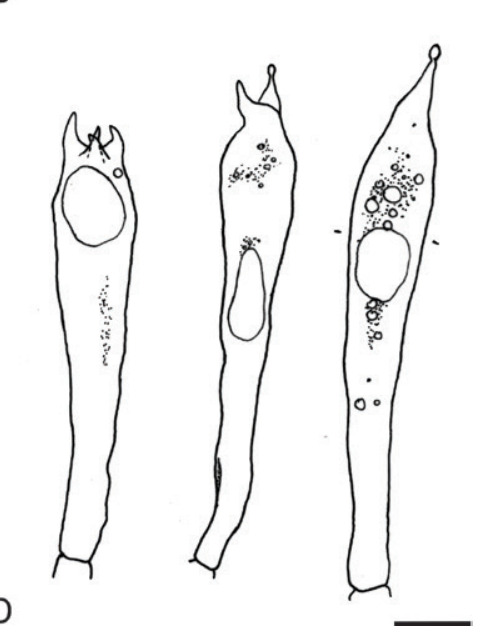

Fig. 16. Overview of different basidium types found in the genus Lactifluus. A. Long and slender basidia in Lf. albomembranaceus (EDC 12-046). B. Short and clavate basidia in Lactifluus sp. (EDC 14-061). C. Four-spored basidia in Lf. heimii (EDC 11-082). D. One-, two- and four-spored basidia in Lf. bicapillus (EDC 12-071) [Scale bar $=10 \mu \mathrm{m}$. Line drawings by E. De Crop]. 


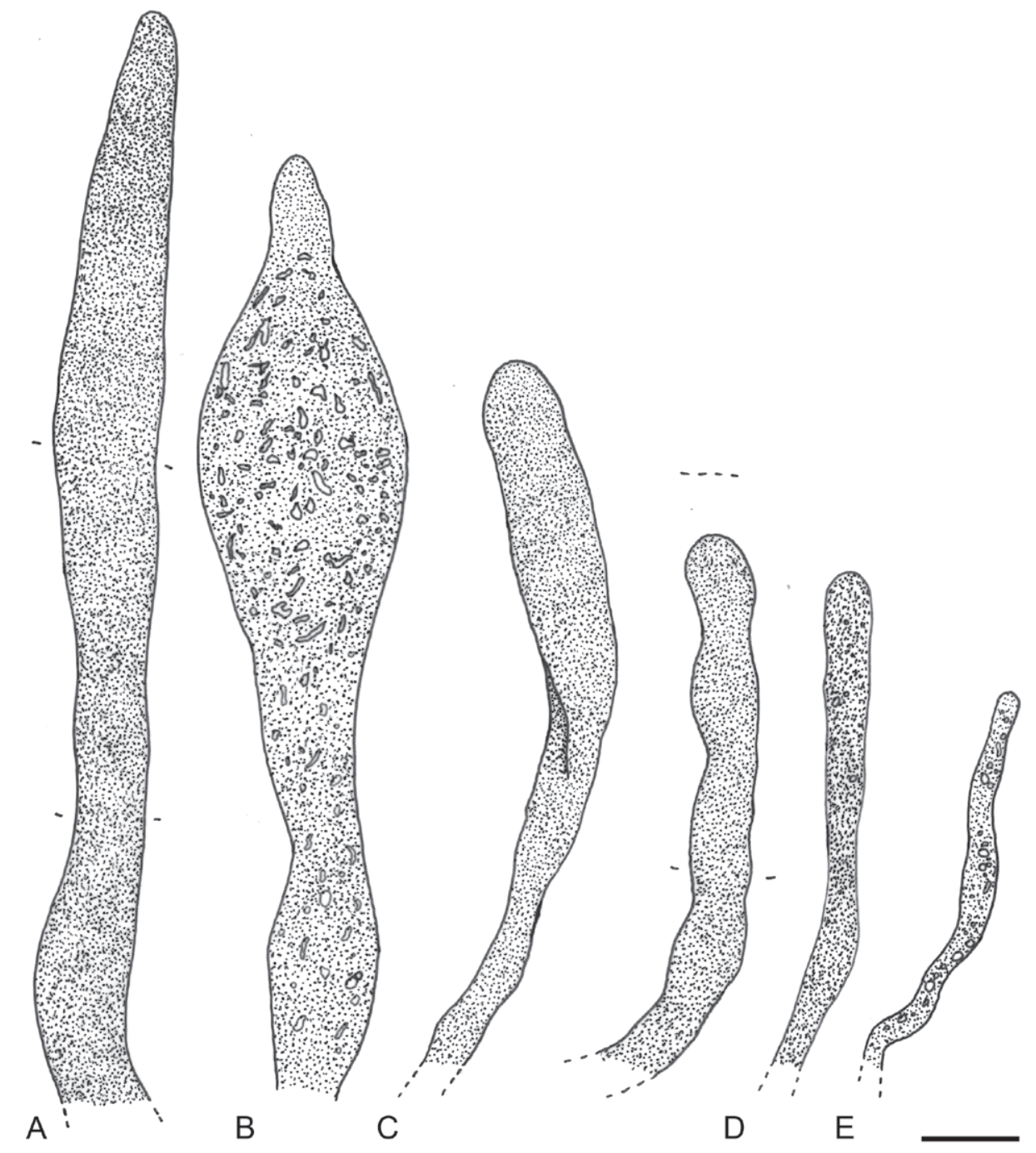

Fig. 17. Overview of different pseudocystidium types found in the genus Lactifluus. A. Broad and emergent pseudocystidium in Lactifluus sp. (EDC 12-040). B. Very broad pseudocystidium in Lactifluus sp (EDC 12-030). C. Not emergent pseudocystidia in Lf. cyanovirescens (FN 05-631). D. Narrow pseudocystidium in Lactifluus sp. (JN 2011-071). E. Very narrow pseudocystidium in Lf. cf. phlebonemus (EDC 12-067) [Scale bar = 10 $\mu$ m. Line drawings by E. De Crop (A-C, E) and S. De Wilde (D)].

the hymenophoral trama, such as in species of $L f$. sect. Lactifluus. Macrocystidia: thin-walled cystidia with a specific content, which is oil-like, needle-like or granular. Their top is rounded, tapering or moniliform.

Leptocystidia: thin-walled cystidia, without a remarkable content, but with a deviating shape. They are rather rare in Lactifluus.

Next to different types of cystidia, some Lactifluus species have sterile elements in their hymenium (Fig. 19). These cells are septate, thin-walled, with no remarkable content and no deviating shape. They are cylindrical and usually ending blunt. Dierickx et al. (2019b) dismiss the idea that these cells represent basidioles or cystidia. They are known to occur in a handful of species (Delgat et al. 2017, De Crop et al. 2019, Dierickx et al. 2019b), but due to their unremarkable shape and content, they might be overlooked and thus more common than currently known.

The lamella edge may contain different elements, such as pseudocystidia, true cystidia, basidioles, basidia, sterile elements or marginal cells. Cheilopseudocystidia, true cystidia and other elements that are present at the lamella edge are often smaller than those on the lamella sides. In several Lactifluus species, the lamella edge is sterile and entirely composed of sterile marginal cells (Fig. 20). These marginal cells are either thin- or thick-walled, hyaline, with a clavate, fusiform to irregular shape (Verbeken \& Walleyn 2010).

Russulaceae species, together with many species of other Russulales families, are characterised by basidiospores with an amyloid spore ornamentation (Fig. 21). In Lactifluus, the spore ornamentation patterns are important in delimiting species or sections, and range from isolated warts and warts connected with fine connective lines, to a complete reticulum. Spore ornamentation can be very low ( $<0.1 \mu \mathrm{m}$ in $L$ f. indusiatus) to rather high (ridges up to $2.3 \mu \mathrm{m}$ in $L f$. longipilus). The plage (smooth area just above the apiculus) is either inamyloid, centrally amyloid, distantly amyloid or completely amyloid. The length and width of Lactifluus spores are measured in side view, excluding ornamentation. Most Lactifluus spore dimensions fit the following range $6.1-13.4 \times 4.8-11.1 \mu \mathrm{m}$. Lactifluus carmineus has the longest spores (11.0-13.4 $\mu \mathrm{m}$ long), while $L f$. conchatulus has the shortest spores (6.1-7.8 $\mu \mathrm{m}$ long). Lactifluus subvolemus has the broadest spores (7.3-11.1 $\mu \mathrm{m}$ broad), while $L f$. foetens has the narrowest spores (4.8-6.5 $\mu \mathrm{m}$ broad). The overall spore shape is determined by the length : width-ratio (quotient or 

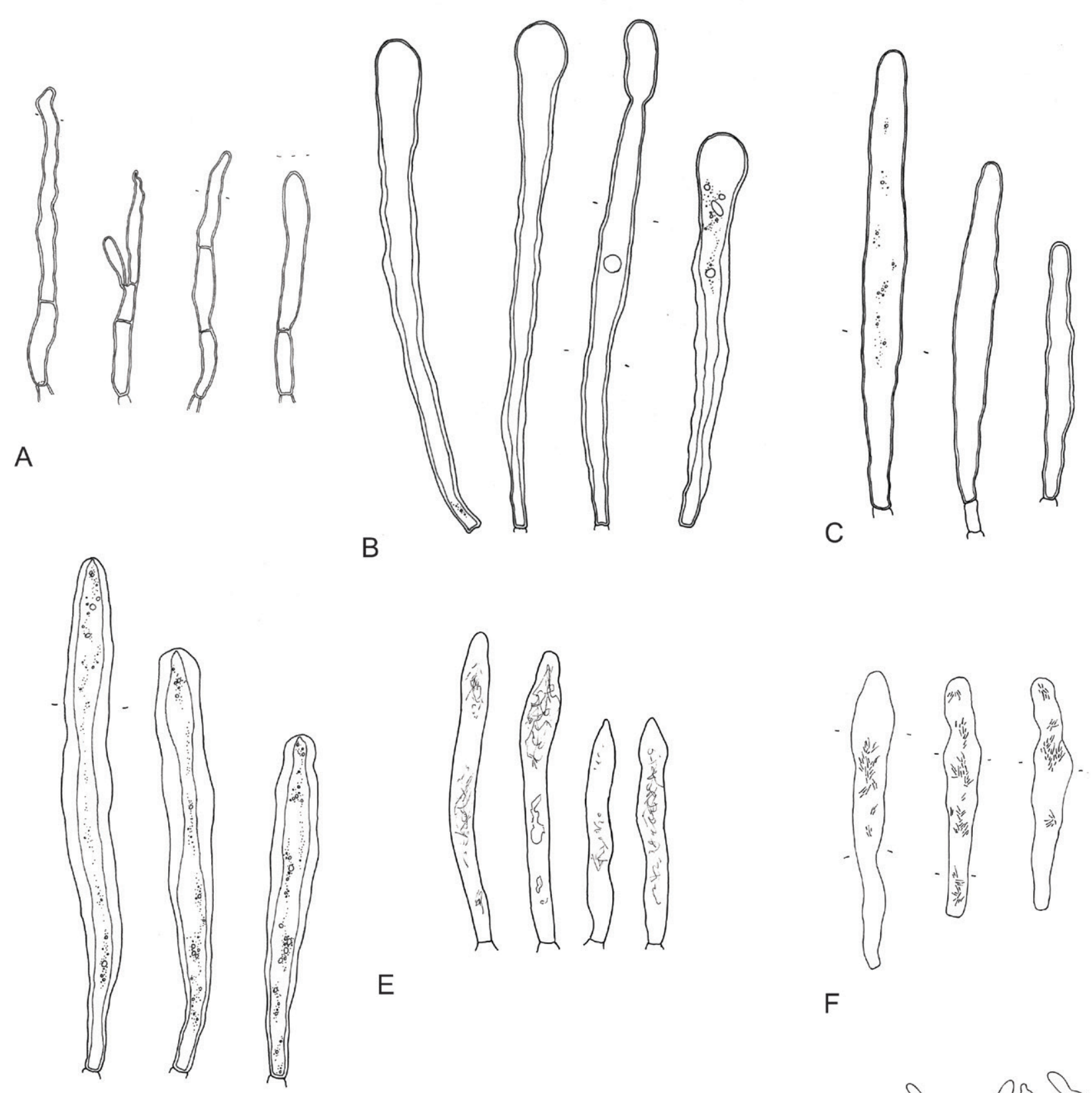

E

$\mathrm{F}$

D
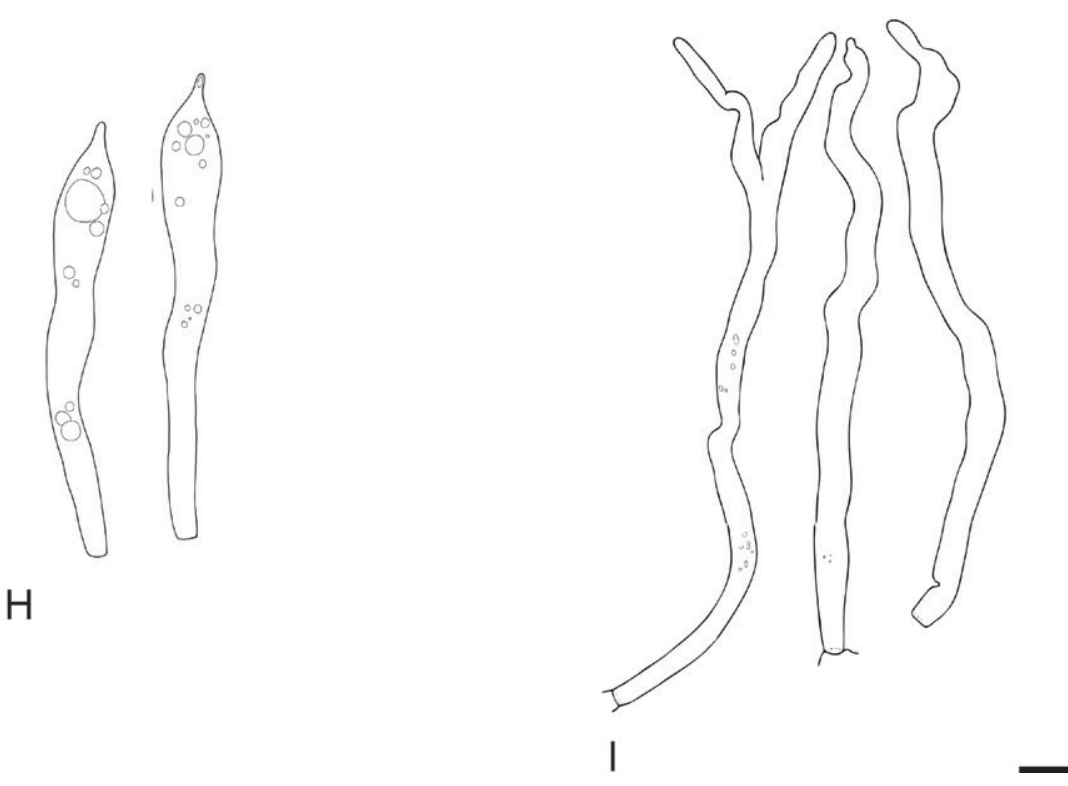

Fig. 18. Overview of different true cystidium types found in the genus Lactifluus. A-D Lamprocystidia. A. In $L f$. armeniacus (EDC 14-501). B. In $L f$. kigomaensis (AV 11-006). C. In Lf. cf. pumilus (EDC 12-066). D. In Lf. cf. volemus (REH 9320). E-F Macrocystidia. E. In Lf. hallingii (REH 7993). F. In Lf. roseophyllus (JN 2011-076). G-I Leptocystidia. G. In Lf. ruvubuensis (AV 94-599). H. In Lf. indusiatus (AV 94-122). I. In Lf. densifolius (BB 3601) [Scale bar $=10 \mu \mathrm{m}$. Line drawings by E. De Crop (A-D, F), L. Delgat (E) and A. Verbeken (G-I)]. Adapted from fig. 2 from De Crop et al. (2017). 


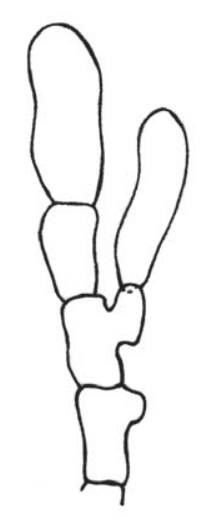

A
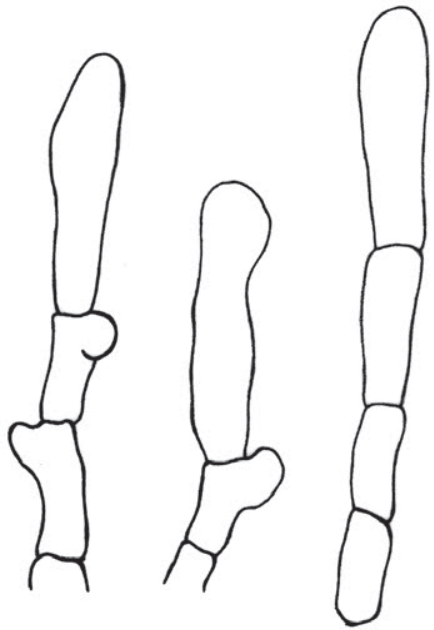

B
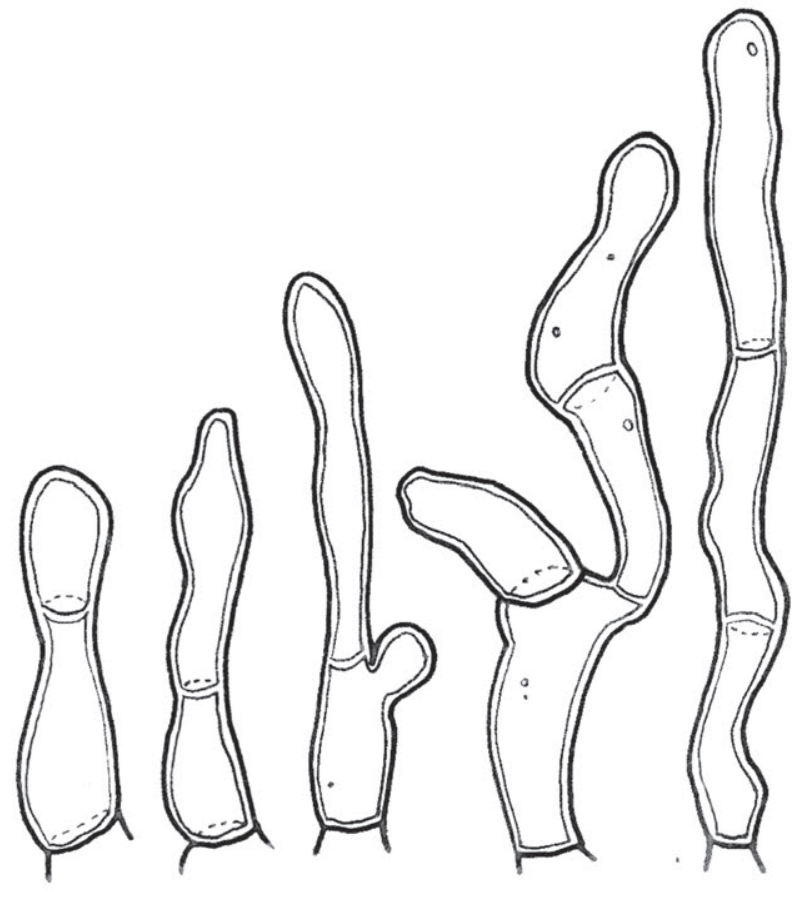

Fig. 19. Overview of different types of sterile elements found in the genus Lactifluus. A. Thin-walled, cylindrical, and septate sterile elements, sometimes with clamp-like bulges under the septum, of Lf. bicapillus (EDC 12-169, adapted from De Crop et al. 2019). B. Cylindrical, septate, and slightly thick-walled sterile elements of the hymenium in Lf. persicinus (EDC 14-376, EDC 14-371 and EDC 14-380, adapted from Delgat et al. 2017). [Scale bar $=10 \mu \mathrm{m}]$.
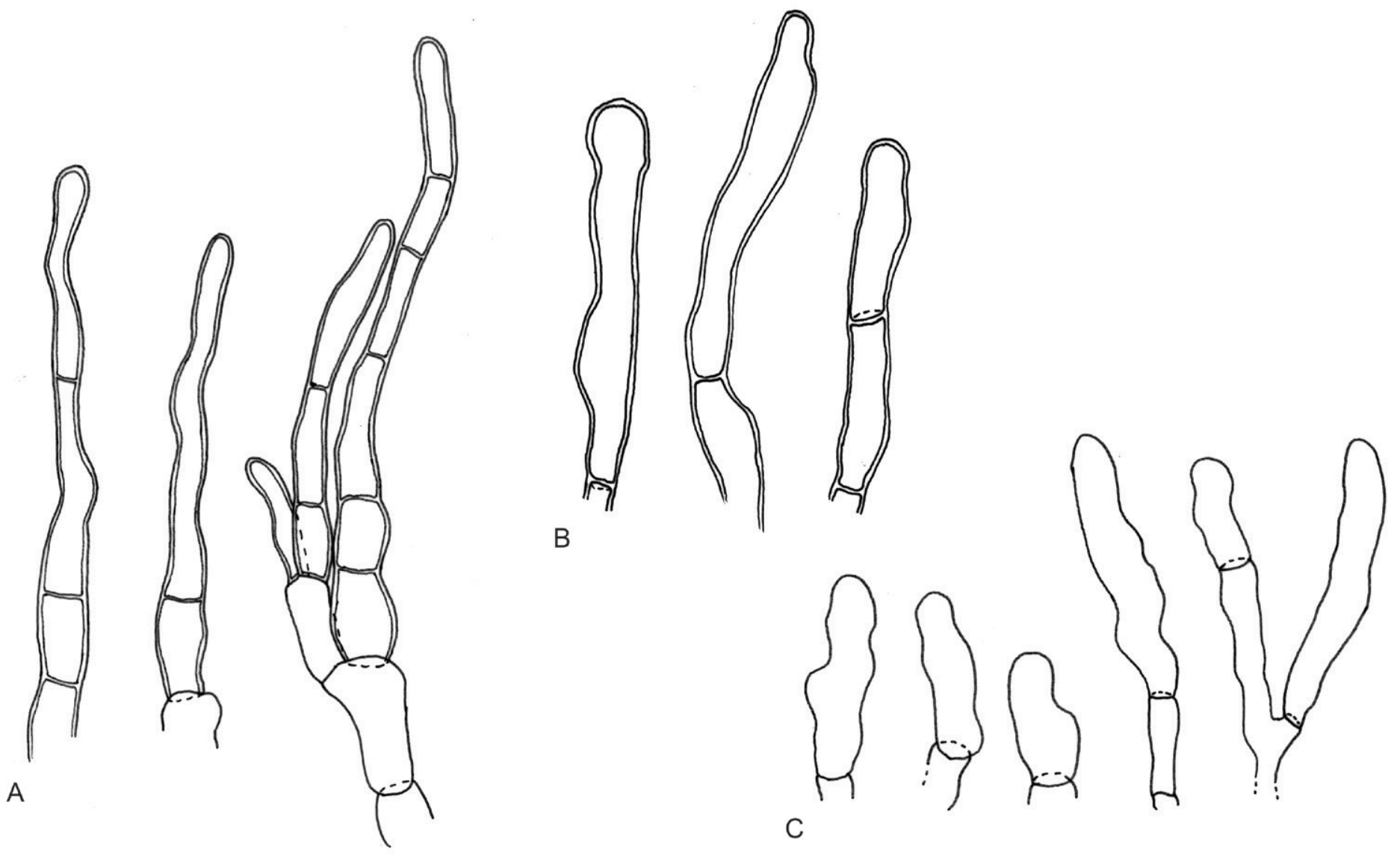

Fig. 20. Overview of different marginal cell types found in the genus Lactifluus. A. Lf. russulisporus (REH 9398). B. Lf. armeniacus (EDC 14-501). C. Lf. cf. phlebonemus (EDC 12-067) [Scale bar $=10 \mu \mathrm{m}$. Line drawings by E. De Crop (A-C)]. 

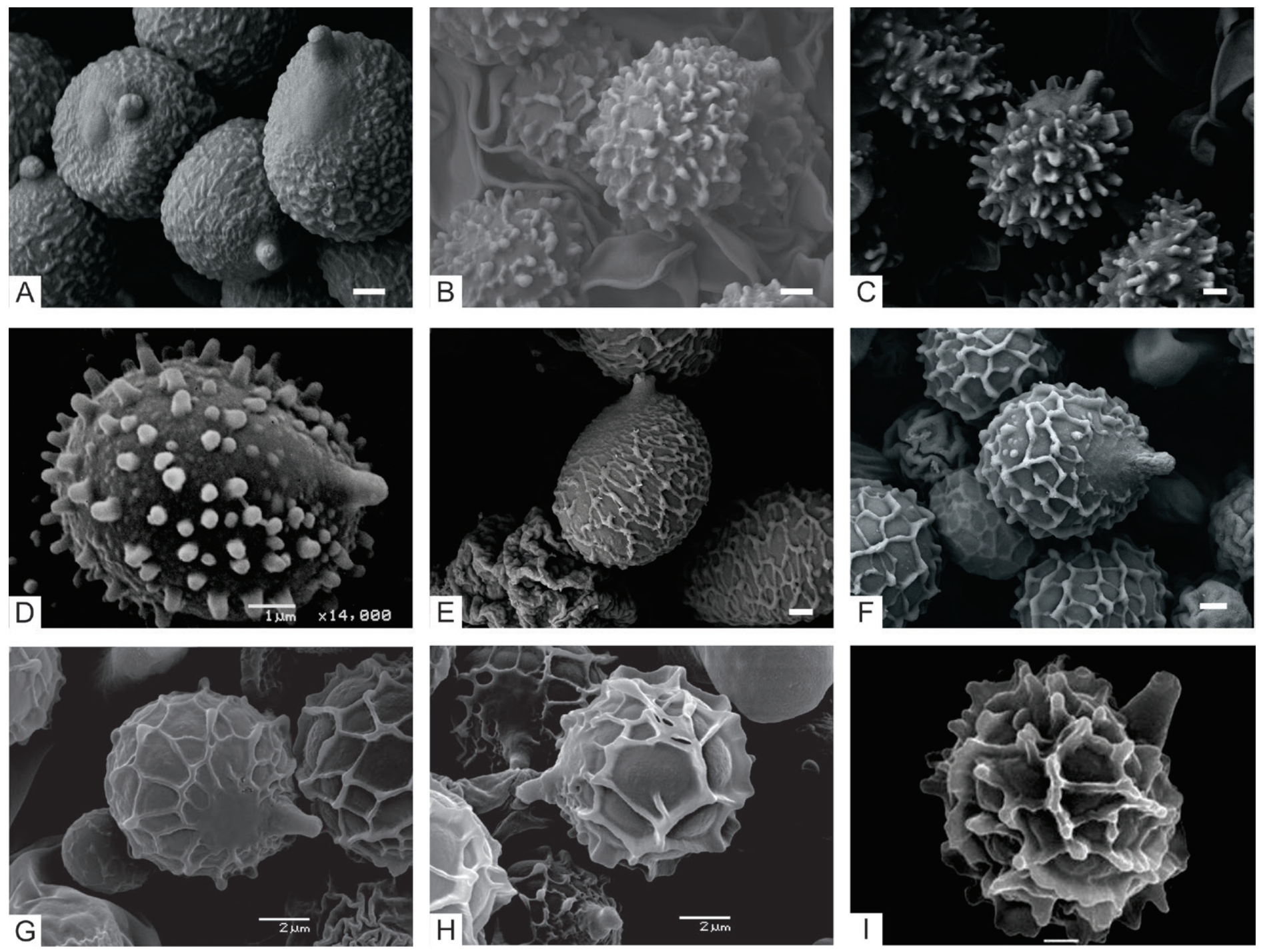

Fig. 21. SEM pictures of different basidiospore types found in the genus Lactifluus. A. Very low ornamentation in Lf. ramipilosus (EDC 14-503). B. Ornamentation of warts connected by fine connective lines in Lf. albomembranaceus (EDC 12-046). C. Ornamentation of high warts connected by fine connective lines in Lf. caliendrifer (KW 378). D. Rounded warts in Lf. angustus (MGF 713). E. Low ornamentation forming an almost complete reticulum in Lactifluus sp. (AV 11-029). F. Ornamentation forming an almost complete reticulum in Lf. armeniacus (EDC 14-501). G. Reticulated ornamentation in Lf. volemus (KVP 08-045). H. Reticulated ornamentation with moderately high ridges in Lf. oedematopus (RW 1228). I. Reticulated ornamentation with high ridges and warts in $L f$. aff. gerardii (LTH 270) (Scale bar $=1 \mu \mathrm{m}$ ).

Q-value): globose spores are defined by a Q-value ranging from 1.00-1.05, subglobose spores by $Q$ between 1.06-1.12, ellipsoid spores by $Q$ between 1.13-1.39 and elongate spores by $Q>1.39$ (Verbeken \& Walleyn 2010). The spore shape in Lactifluus species ranges between subglobose to ellipsoid (average $Q$ between 1.10-1.37), only a few species have globose spores, such as in some $L f$. oedematopus collections $(Q=1)$ or elongate spores, such as in some $L f$. longisporus collections $(Q=1.6)$.

Hymenophoral trama in Lactifluus typically consists of isodiametric sphaerocytes (globose cells), sometimes in combination with hyphae, and rarely only hyphae (Fig. 22). In between the trama, lactiferous hyphae are found. They have a refringent, dense, oleiferic, or needle-like to granular content and are rather broad $(4-16 \mu \mathrm{m})$. In some species they are abundant, while scarce in others.

\section{Characteristics of the ectomycorrhizas}

The ectomycorrhizas of only very few Lactifluus species have been studied until now: Lf. piperatus (Beenken 2004), Lf. rugatus
(Leonardi et al. 2016), Lf. vellereus (Grebenc et al. 2009) and Lf. aff. volemus (Kumar \& Atri 2016). Leonardi et al. (2016) concluded that there are no significant ECM features shared by those four species, which reflects their relatively far phylogenetic distance (from three different subgenera).

The different mantle layers can be plectenchymatous to pseudoparenchymatous. The outer mantle layer may contain cystidia (L. rugatus), extramatrical hyphae (L. piperatus and $L$. aff. volemus) or a hyphal net (L. vellereus). Lactifers may be present in the inner mantle layer ( $L$. vellereus and $L$. aff. volemus). Rhizomorphs are sometimes present (L. piperatus and $L$. vellereus). See Leonardi et al. (2016) for a more detailed description of ECM characteristics.

\section{Ethnomycological uses}

Wild edible mushrooms, often ectomycorrhizal fungi, are one of the more important renewable natural resources in many regions worldwide. Milkcap species are easily recognised and often 


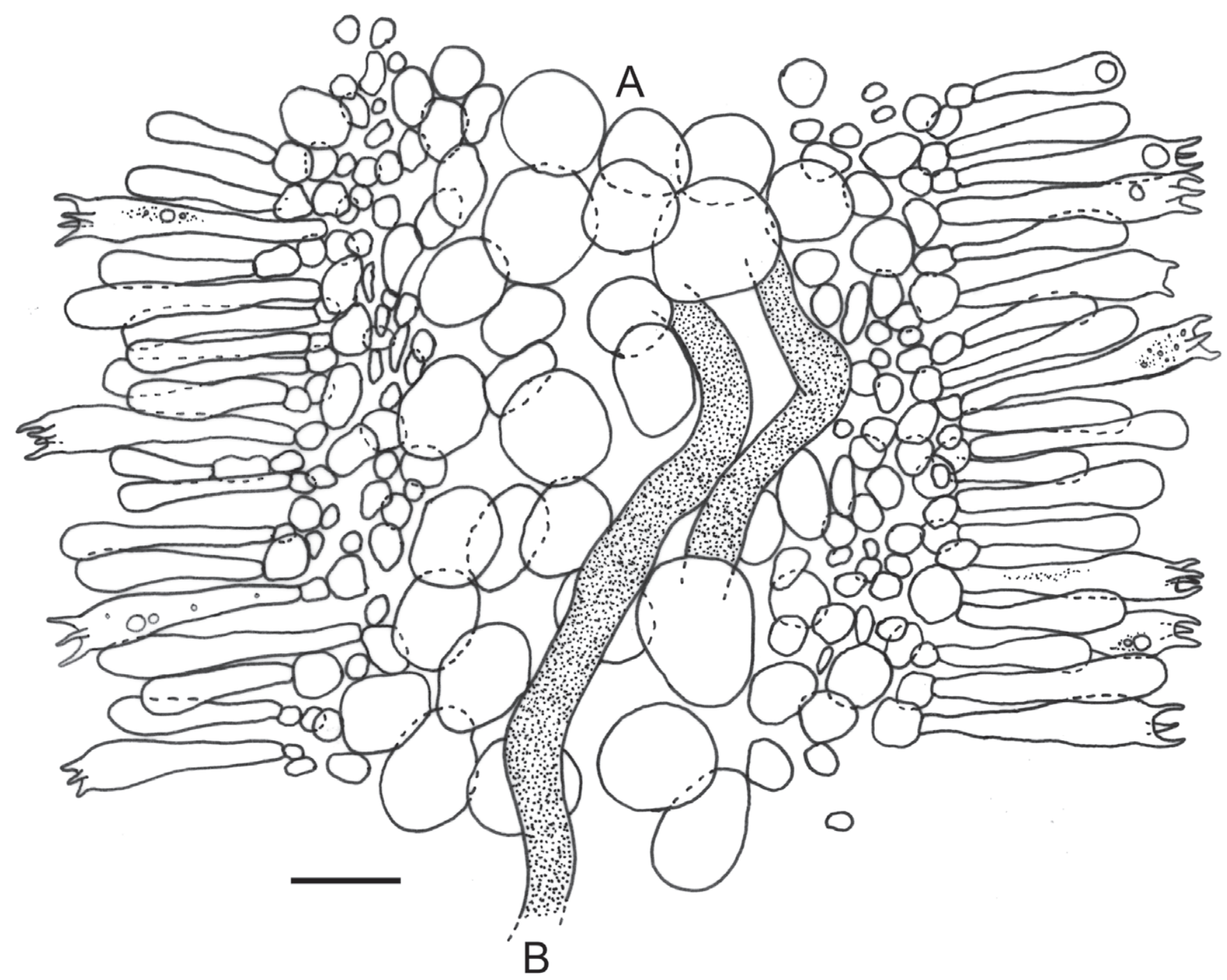

Fig. 22. Section through the hymenium in Lactifluus sp. (EDC 14-060). A. Cellular trama. B. Lactiferous hyphae (Scale bar $=25 \mu \mathrm{m}$. Line drawing by E. De Crop).

fruit in large numbers, which makes them popular at markets. Depending on the culture, different species are consumed and prepared in a variety of ways. Species of the genus Lactifluus are consumed in large parts of Africa, Asia, Europe, Central and North America (Nuytinck et al. 2020).

In many sub-Saharan African countries, mushrooms are of great importance to the local people. Large parts of these countries are covered by Sudanian or Miombo woodlands, by a woodland-savannah mosaic intermingled with riparian forests, or by rainforests; and all those vegetation types are characterised by the occurrence of a variety of ECM trees. In regions with woodland or riparian forests, fungi fruit in large numbers at the beginning of the rain season, which is the traditional hunger period (Rammeloo \& Walleyn 1993, Smith \& Allen 2004). Mushrooms are eaten fresh, dried or cooked (Fig. 23). Milkcap species, especially the sharp-tasting species, are often parboiled, and the boiling water is thrown away (Härkönen et al. 2003). Mushrooms are commonly sold on markets and along roadsides, particularly by women and children (Härkönen et al. 2003, Mittermeier et al. 2003, Williams et al. 2008).

Some Lactifluus species are eaten over their whole range of distribution, such as $L f$. densifolius, $L f$. edulis, Lf. gymnocarpoides, $L f$. gymnocarpus, or $L f$. rubroviolascens. Others are only eaten locally, such as $L f$. albomembranaceus, $L f$. brunnescens, $L f$. longipes, and Lf. persicinus in Cameroon (Njouonkou et al. 2016);
Lf. heimii, Lf. luteopus, and Lf. xerampelinus in Tanzania (Härkönen et al. 2003); Lf. brunnescens and Lf. longisporus in Haut-Katanga (DRC; De Kesel et al. 2017); Lf. flammans in Benin (De Kesel et al. 2002, Yorou et al. 2014); Lf. rubiginosus in Zambia (Härkönen et al. 2015); or Lf. brachystegiae in Zimbabwe (Sharp 2011, 2014).

Lactifluus species are traditionally appreciated in many European, Asian, North and Central American countries. In particular, $L f$. volemus and its sister species from $L f$. sect. Lactifluus are eaten in many countries over their entire range of distribution (Russell 2006, Wang \& Yang 2006, Garibay-Orijel et al. 2007, Le 2007, Liu et al. 2009, Lincoff 2010, Van de Putte 2012, Nuytinck et al. 2020). These species often have large sporocarps which are easy to identify, even by non-experts, and they can locally fruit in large numbers (Van de Putte 2012). Species of $L f$. sect. Pseudogymnocarpi (e.g. Lf. rugatus or $L f$. hygrophoroides) are also popular and eaten in almost every country where these often brightly coloured species with large sporocarps occur (Marchand 1980, Bessette et al. 1997, Foiera et al. 1998, Roody 2003, Miller \& Miller 2006, Bessette 2007). Species of $L f$. sect. Albati and $L f$. sect. Piperati have white, large and firm sporocarps with an acrid taste. These are only eaten in certain regions, often after removing the acrid taste by parboiling or preservation with salt (Montoya \& Bandala 1996, Heilmann-Clausen et al. 1998), but in other regions they are considered poisonous (Bessette 2007). Other species are only 

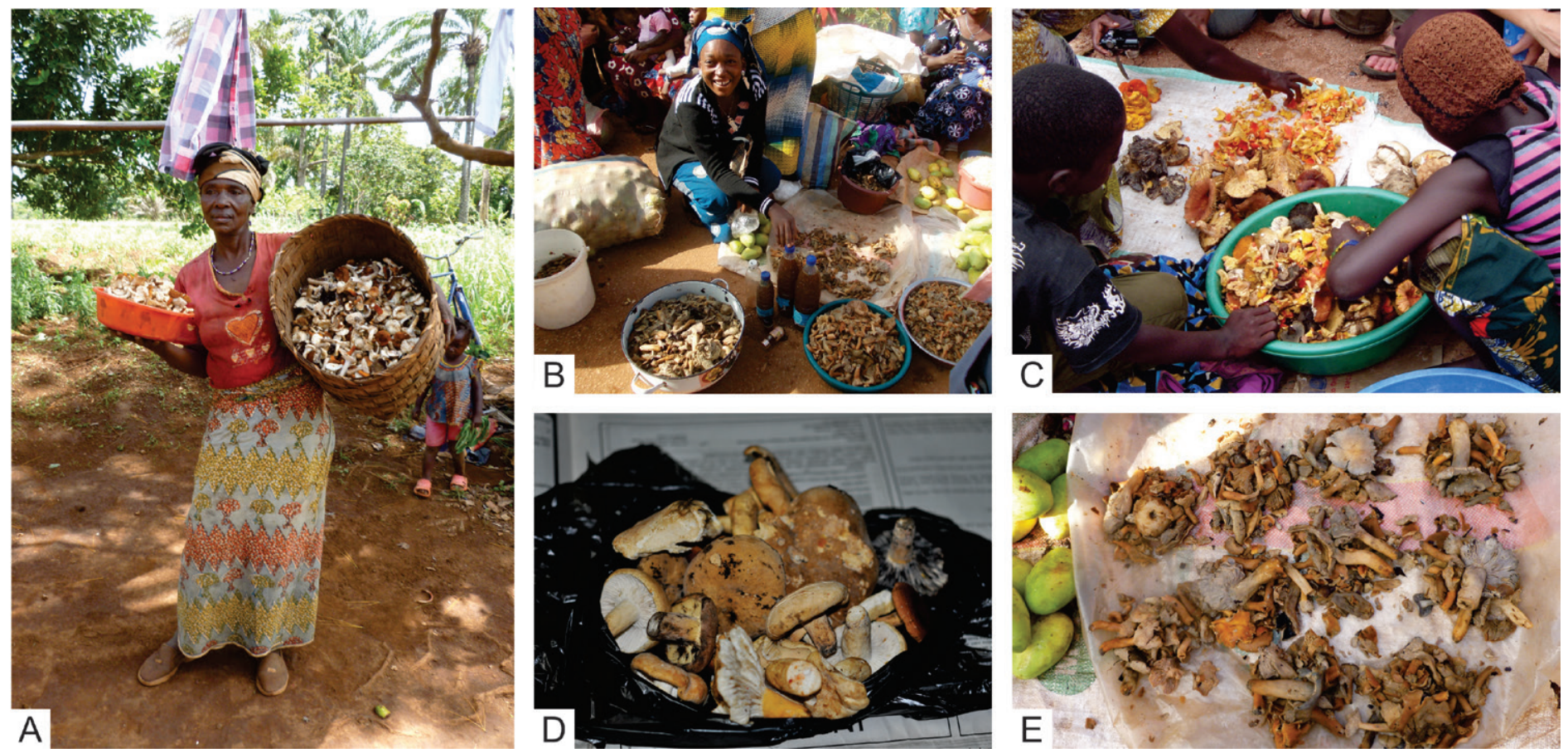

Fig. 23. Edible Lactifluus species in Africa. A. Our local guide with a basket full of Lactifluus species (Foumban, Cameroon). B. Cooked Lactifluus species for sale on the market (Foumban, Cameroon). C. Lactifluus species for sale on the market (Kigoma, Tanzania). D. A variety of Lactifluus species collected for consumption (Kigoma, Tanzania). E. Cooked Lactifluus species (Foumban, Cameroon) [Photographs by A.L. Njouonkou (B) and E. De Crop $(\mathrm{A}, \mathrm{C}-\mathrm{E})]$.

eaten locally, such as species from $L f$. sect. Luteoli, Lf. sect. Gerardii or Lf. sect. Tenuicystidiati (Roody 2003, Bessette 2007, Nuytinck et al. 2020).

To our knowledge, few Lactifluus species are only occasionally eaten in Australasia (e.g. Lf. aff. piperatus and Lf. wirrabara, pers. comm. T. Lebel), and some are considered being poisonous (e.g. Lf. aff. piperatus; Grgurinovic 1997). We currently have no records of consumed Lactifluus species in northeastern South America (T. Henkel, pers. comm.).

\section{Bioactive secondary metabolites}

Lactifluus species are known to contain bioactive secondary metabolites in their sporocarps. Several Lactifluus species are reported to have anti-mutagen properties, such as Lactifluus volemus (Wasser 2002, Dai et al. 2009, Van de Putte 2012) or Lf. vellereus (Mlinaric et al. 2004). In China, Lf. cf. vellereus contains a highly functionalized lactarane sesquiterpene, velleratretraol, which shows weak anti-HIV activity (Luo et al. 2009). Some Lactifluus species appear effective as antioxidant agent due to their bioactive compounds, such as the Asian representatives of Lf. cf. volemus and Lf. cf. piperatus (Ferreira et al. 2009, Ozen et al. 2011, Abdullah et al. 2012, Van de Putte 2012, Joshi et al. 2013) and the European Lf. rugatus (Sevindik 2020), Lf. vellereus and Lf. bertillonii (Heleno et al. 2012). Lactifluus piperatus is reported to have possibilities as a biosorbent and can be used to remove cadmium (Cd II) and zinc ( $\mathrm{Zn} \mathrm{II)} \mathrm{ions} \mathrm{from} \mathrm{wastewater}$ (Nagy et al. 2014a, b). In Turkey, Lf. vellereus and Lf. rugatus are used as food and as traditional medicine and respectively Dogan et al. (2013) and Sevindik (2020) showed that they indeed have antimicrobial properties.

\section{ACKNOWLEDGEMENTS}

E. De Crop (grants B/13485/01 and BOF-PDO-2017-001201) and L. Delgat (grant BOF-DOC-2015-007001) are supported by the "Special Research Fund Ghent University" (BOF). We thank Nathan Schoutteten, Ruben Walleynt, Terry Henkel, Felix Hampe, Guo Jiayu, Todd Elliot, Gianluigi Boerio (www.bogiphoto.com), Kobeke Van de Putte, Dirk Stubbe, Dan Molter and André-Ledoux Njouonkou for providing pictures of Lactifluus or other Russulales species. We thank Kobeke Van de Putte, Dirk Stubbe, and Serge De Wilde for providing line drawings. We thank Botanic Garden Meise, Bertie-Joan Van Heuven and Yoran Toonen both from Naturalis Biodiversity Center for making the SEM pictures. We thank Research Foundation Flanders (FWO), the King Leopold III Fund for Nature Exploration and Conservation, and the Faculty Committee Scientific Research (FCWO) of Ghent University for supporting various mycological surveys which led to collections for this study. We would like to thank everyone who provided material for this and previous studies on Lactifluus.

Conflict of interest: The authors declare that there is no conflict of interest.

\section{REFERENCES}

Abdullah N, Ismail SM, Aminudin N, et al. (2012). Evaluation of Selected Culinary-Medicinal Mushrooms for Antioxidant and ACE Inhibitory Activities. Evidence-Based Complementary and Alternative Medicine 2012: 464238.

Basso MT (1999). Lactarius Pers. Fungi Europaei 7. Mykoflora, Alassio: Italy.

Beeli M (1928). Contribution à l'étude de la flore mycologique de Congo. Fungi Goossensiani V. Bulletin de la Société royale de botanique de Belgique 60: 153-174. 
Beeli M (1936). Contribution à l'étude de la flore mycologique du Congo. XI. Fungi Goossensiani. XII. Fungi Loosiani. Bulletin du Jardin botanique de l'état, Bruxelles Bulletin van de Rijksplantentuin, Brussel 14: 83-91.

Beenken L (2004). Die Gattung Russula Untersuchungen zu ihrer Systematik anhand von Ektomykorrhizen. PhD thesis, University of Munich, Munich, Germany.

Bera I, Das K (2019). Lactifluus indovolemus sp. nov. and two new records in the Lactifluus volemus complex from India. Nordic Journal of Botany 37: e02483.

Berkeley MJ (1852). Decades of Fungi, decades XXXIX, XL. Sikkim and Khassya Fungi. Hooker's Journal of Botany 4: 130-142.

Berkeley MJ, Curtis MA (1859). Centuries of North American fungi. Annals and Magazine of Natural History 4: 284-296.

Bessette A (2007). Mushrooms of the Southeastern United States. Syracuse University Press, Syracuse: NY, USA.

Bessette A, Bessette AR, Fisher DW (1997). Mushrooms of northeastern North America. Syracuse University Press, Syracuse: NY, USA.

Binder M, Bresinsky A (2002). Derivation of a polymorphic lineage of Gasteromycetes from boletoid ancestors. Mycologia 94: 85-98.

Bissett A, Fitzgerald A, Meintjes T, et al. (2016). Introducing BASE: the Biomes of Australian Soil Environments soil microbial diversity database. Gigascience 5: 11.

Blackwell M (2011). The Fungi: 1, 2, 3 ... 5.1 million species? American Journal of Botany 98: 426-438.

Bon M (1971). Un nouveau Lactaire de la section 'Plinthogali' (Burl.) Sing. (= Fuliginosi Konrad): Lactarius brunneo-violascens Bon n.sp. Documents Mycologiques 1: 45-48.

Brotzu R (1998). Funghi della Sardegna. Nuoro, Italy.

Buyck B (1989). New taxa of Central African Russulaceae. Bulletin du Jardin Botanique National de Belgique 59: 241-253.

Buyck B (1994). Ubwoba: les champignons comestibles de l'ouest du Burundi. Administration générale de la coopération au développement, Bruxelles.

Buyck B, Atri NS (2011). A Russula (Basidiomycota, Russulales) with an unprecedented hymenophore configuration from northwest Himalaya (India). Cryptogamie, Mycologie 32: 185-190.

Buyck B, Hofstetter V, Eberhardt U, et al. (2008). Walking the thin line between Russula and Lactarius: the dilemma of Russula subsect. Ochricompactae. Fungal Diversity 28: 15-40.

Buyck B, Hofstetter V, Verbeken A, et al. (2010). Proposal 1919: To conserve Lactarius nom. cons. (Basidiomycota) with a conserved type. Mycotaxon 111: 504-508.

Buyck B, Horak E (1999). New taxa of pleurotoid Russulaceae. Mycologia 91: 532-537.

Buyck B, Verbeken A, Eberhardt U (2007). The genus Lactarius in Madagascar. Mycological Research 111: 787-798.

Calonge FD, Martín MP (2000). Morphological and molecular data on the taxonomy of Gymnomyces, Martellia and Zelleromyces (Russulales). Mycotaxon 76: 9-15.

CBD (2006). Guide to the Global Taxonomy Initiative. CBD Technical Series No. 30.

Cheek M, Lughadha EC, Kirk P, et al. (2020). New scientific discoveries: Plants and fungi. Plants, People and Planet 2: 371-388.

Cleland JB, Cheel EC (1919). Australian fungi: notes and descriptions. Transactions and Proceedings of the Royal Society of South Australia 43: 262-315.

Cleland JBMD (1927). Australian Fungi: notes and descriptions $n^{\circ} 6$. Transactions and Proceedings of the Royal Society of South Australia 51: 298-306.

Coker WC (1918). The Lactariae of North Carolina. Journal of the Elisha Mitchell Scientific Society 34: 1-61.
Comandini O, Contu M, Rinaldi AC (2006). An overview of Cistus ectomycorrhizal fungi. Mycorrhiza 16: 381-395.

Courtecuisse R, Buyck B (1991). Eléments pour un inventaire mycologique des environs du Saut Pararé (Arataye) et de l'Inselberg des Nouragues (Guyane Française). VI. Russulaceae. Mycologia Helvetica 4: 209-225.

Crossland C (1900). New and critical British fungi found in Western Yorkshire. The Naturalist 516: 5-10.

Crous PW, Cowan DA, Maggs-Kölling G, et al. (2020a). Fungal Planet description sheets: 1112-1181. Persoonia 45: 251-409.

Crous PW, Wingfield MJ, Burgess $\mathrm{TI}$, et al. (2017). Fungal Planet description sheets: 625-715. Persoonia 39: 270-467.

Crous PW, Wingfield MJ, Chooi YH, et al. (2020b). Fungal Planet description sheets: 1042-1111. Persoonia 44: 301-459.

Crous PW, Wingfield MJ, Lombard L, et al. (2019). Fungal Planet description sheets: 951-1041. Persoonia 43: 223-425.

Dai YC, Yang ZL, Cui BK, et al. 2009 Species diversity and utilization of medicinal mushrooms and fungi in China (review). International Journal of Medicinal Mushrooms 11: 287-302.

Das K, Ghosh A, Chakraborty D, et al. (2017). Fungal Biodiversity Profiles 31-40. Cryptogamie, Mycologie 38: 353-406.

Das K, Sharma JR, Verbeken A (2003). New species of Lactarius from Kumaon Himalaya, India. Mycotaxon 88: 333-342.

De Crop E (2016). Global phylogeny and evolutionary history of the genus Lactifluus. PhD thesis, Biology, Ghent University, Ghent

De Crop E, Hampe F, Wisitrassameewong K, et al. (2018). Novel diversity in Lactifluus section Gerardii from Asia: five new species with pleurotoid or small agaricoid basidiocarps. Mycologia 110: 1-23.

De Crop E, Lescroart J, Njouonkou AL, et al. (2019). Lactifluus bicapillus (Russulales, Russulaceae), a new species from the Guineo-Congolian rainforest. MycoKeys 45: 25-39.

De Crop E, Nuytinck J, Van de Putte K, et al. (2014). Lactifluus piperatus (Russulales, Basidiomycota) and allied species in Western Europe and a preliminary overview of the group worldwide. Mycological Progress 13: 493-511.

De Crop E, Nuytinck J, Van de Putte K, et al. (2017). A multi-gene phylogeny of Lactifluus (Basidiomycota, Russulales) translated into a new infrageneric classification of the genus. Persoonia 38: 58-80.

De Crop E, Tibuhwa D, Baribwegure D, et al. (2012). Lactifluus kigomaensis sp. nov. from Kigoma province, Tanzania. Cryptogamie, Mycologie 33: 421-426.

De Crop E, Van de Putte K, De Wilde S, et al. (2016). Lactifluus foetens and Lf. albomembranaceus sp. nov. (Russulaceae): look-alike milkcaps from gallery forests in tropical Africa. Phytotaxa 277: 159-170.

De Kesel A, Codjia JTC, Yorou NS (2002). Guide des champignons comestibles du Bénin. Jardin botanique national de Belgique, Meise: Belgium.

De Kesel A, Kasongo B, Degreef J (2017). Champignons comestibles du Haut-Katanga (R. D. Congo). Abc Taxa 17: i-vi, 1-290.

De Lange R, De Crop E, Delgat L, et al. (2018). Lactifluus kigomaensis and L. subkigomaensis: two look-alikes in Tanzania. Mycoscience 59: 371-378.

Delgat L, Courtecuisse R, De Crop E, et al. (2020). Lactifluus (Russulaceae) diversity in Central America and the Caribbean: melting pot between realms Persoonia 44: 278-300.

Delgat L, De Crop E, Njouonkou AL, et al. (2017). Lactifluus persicinus sp. nov. from the gallery forests of West Cameroon. Mycotaxon 132: 471-483.

Delgat L, Dierickx G, De Wilde S, et al. (2019). Looks can be deceiving: the deceptive milkcaps (Lactifluus, Russulaceae) exhibit low morphological variance but harbour high genetic diversity. IMA Fungus 10: 14. 
Dennis RWG (1970). Fungus Flora of Venezuela and adjacent countries. Kew Bulletin Additional Series 111: 1-531.

Desjardin DE (2003). A unique ballistosporic hypogeous sequestrate Lactarius from California. Mycologia 95: 148-155.

Dierickx G, Froyen M, Halling R, et al. (2019a). Nomenclatural Novelties. Index Fungorum 392: 1.

Dierickx G, Froyen M, Halling R, et al. (2019b). Updated taxonomy of Lactifluus section Luteoli: L. russulisporus from Australia and $L$. caliendrifer from Thailand. MycoKeys 56: 13-32.

Dogan HH, Duman R, Ozkalp B, et al. (2013). Antimicrobial activities of some mushrooms in Turkey. Pharmaceutical Biology 51: 707-711.

Donk MA (1971). Progress in the study of the classification of the higher Basidiomycetes. In: Evolution in the higher Basidiomycetes. (Petersen $\mathrm{RH}$, ed.). The University of Tennessee Press, Knoxville, USA: 3-25.

Duque Barbosa JA, Delgat L, Galváo Elias S, et al. (2020). A new section, Lactifluus section Neotropicus (Russulaceae), and two new Lactifluus species from the Atlantic Forest, Brazil. Systematics and Biodiversity 18: 347-361.

Eberhardt U, Verbeken A (2004). Sequestrate Lactarius species from tropical Africa: L. angiocarpus sp. nov. and L. dolichocaulis comb. nov. Mycological Research 108: 1042-1052.

Ferreira I, Barros L, Abreu RMV (2009). Antioxidants in Wild Mushrooms. Current Medicinal Chemistry 16: 1543-1560.

Foiera F, Lazzarini E, Snabl M (1998). Funghi lattari. Bologna : Edagricole: Italy.

Fries EM (1838). Epicrisis Systematis Mycologici, seu synopsis Hymenomycetum. Typographia Academica, Uppsala, Sweden.

Garibay-Orijel R, Caballero J, Estrada-Toress A, et al. (2007). Understanding cultural significance, the edible mushroom case. Journal of Ethnobiology and Ethnomedicine 3: 1-18.

Grebenc T, Christensen M, Vilhar U, et al. (2009). Response of ectomycorrhizal community structure to gap opening in natural and managed temperate beech-dominated forests. Canadian Journal of Forest Research 39: 1375-1386.

Grgurinovic CA (1997). Larger Fungi of South Australia. Botanic Gardens of Adelaide and State Herbarium: Australia.

Härkönen M, Niemelä T, Mbindo K, et al. (2015). Zambian mushrooms and mycology. Norrlinia 29. University of Helsinki's Finnish Museum of Natural History (LUOMUS).

Härkönen M, Niemelä T, Mwasumbi L (2003). Tanzanian mushrooms. Edible, harmful and other fungi. Norrlinia 10. University of Helsinki's Finnish Museum of Natural History (LUOMUS).

Hawksworth D, Lücking R (2017). Fungal diversity revisited: 2.2 to 3.8 million species. In: The Fungal Kingdom (Heitman J, Howlett B, Crous P, et al. eds). ASM Press, Washington, USA: 79-95.

Hawksworth DL (2001). The magnitude of fungal diversity: the 1.5 million species estimate revisited. Mycological Research 105: 1422 1432.

He MQ, Zhao RL, Hyde KD, et al. (2019). Notes, outline and divergence times of Basidiomycota. Fungal Diversity 99: 105-367.

Heilmann-Clausen J, Verbeken A, Vesterholt J (1998). The genus Lactarius Vol. 2 - Fungi of Northern Europe. Svampetryk: Danish Mycological Society, Denmark.

Heim R (1937). Observations sur la flore mycologique malgache V. Les Lactario-Russulés à anneau: Ontogénie et Phylogénie. Revue Mycologique 2: 4-17, 109-117.

Heim R (1938). Diagnoses latines d'espèces et variétés nouvelles de Lactario-Russulés du domaine oriental de Madagascar. Candollea 7: 374-393.

Heim R (1955). Les Lactaires d'Afrique intertropicale (Congo Belge et Afrique Noire Française). Bulletin du Jardin botanique de l'état, Bruxelles Bulletin van de Rijksplantentuin, Brussel 25: 1-91.
Heim R (1966). Breves diagnoses latinae novitatum genericarum specificarumque nuper descriptarum. Revue de Mycologie 30: 231-241.

Heleno SA, Barros L, Martins A, et al. (2012). Phenolic, polysaccharidic, and lipidic fractions of mushrooms from northeastern Portugal: chemical compounds with antioxidant properties. Journal of Agricultural and Food Chemistry 60: 4634-4640.

Henkel TW, Aime MC, Chin MM, et al. (2012). Ectomycorrhizal fungal sporocarp diversity and discovery of new taxa in Dicymbe monodominant forests of the Guiana Shield. Biodiversity and Conservation 21: 2195-2220.

Henkel TW, Aime MC, Miller SL (2000). Systematics of pleurotoid Russulaceae from Guyana and Japan, with notes on their ectomycorrhizal status. Mycologia 92: 1119-1132.

Hennings P (1898). Fungi Novo-guineenses. III. Botanische Jahrbücher für Systematik Pflanzengeschichte und Pflanzengeographie 25: 495-509.

Hennings P (1902). Fungi camerunenses novi III. Botanische Jahrbücher fur Systematik, Pflanzengeschichte und Pflanzengeographie 30: 39-57.

Hesler LR, Smith AH (1979). North American species of Lactarius. University of Michigan Press, Ann Arbor.

Hibbett D (2016). The invisible dimension of fungal diversity. Science 351: 6278.

Hibbett DS, Binder M (2002). Evolution of complex fruiting-body morphologies in homobasidiomycetes. Proceedings of the Royal Society London Biological Sciences 269: 1963-1969.

Hibbett DS, Pine EM, Langer E, et al. (1997). Evolution of gilled mushrooms and puffballs inferred from ribosomal DNA sequences. Proceedings of the National Academy of Sciences of the United States of America 94: 12002-12006.

Hongo T (1964). Memoirs of the Faculty of Education, Shiga University, Pt. 2. Natural Science 15: 46.

Hongo T (1973). On some interesting larger fungi from New Guinea. Reports of The Tottori Mycological Institute Japan 10: 362-364.

Hyde KD, Norphanphoun C, Abreu VP, et al. (2017). Fungal diversity notes 603-708: taxonomic and phylogenetic notes on genera and species. Fungal Diversity 87: 1-235.

Joshi S, Vishwakarma MP, Mahar R, et al. (2013). Medicinally important and edible species of genus Lactarius from Garhwal Himalaya, India. Mycosphere 4: 714-720.

Jülich W (1981). Higher taxa of Basidiomycetes. Bibliotheca Mycologica 85: 1-485.

Karhula P, Härkönen M, Saarimäki T, et al. (1998). Tanzanian mushrooms and their uses. 6. Lactarius. Karstenia 38: 49-68.

Kew R (2016). The State of the World's Plants Report - 2016. Royal Botanic Gardens, Kew.

Kirk PM, Cannon PF, David JC, et al. (eds) (2008). Ainsworth \& Bisby's Dictionary of the fungi. $10^{\text {th }}$ edn. CAB International, Wallingford (Oxon).

Kreisel H (1969). Grundzüge eines natürlichen Systems der Pilze. Verlag VEB Gustav Fischer, Jena.

Kropp BR (2016). Russulaceae in American Samoa: new species and further support for an Australasian origin for Samoan ectomycorrhizal fungi. Mycologia 108: 405-413.

Kühner R, Romagnesi H (1953). Compléments à la "Flore Analytique". II. Espèces nouvelles ou critiques de Lactarius. Bulletin de la Société Mycologique de France 69: 361-388.

Kumar J, Atri NS (2016). Characterization of ectomycorrhizae of Russula and Lactifluus (Russulaceae) associated with Shorea from Indian Shiwaliks. Nova Hedwigia 103: 501-513.

Lalli G, Pacioni G (1992). Lactarius sect. Lactifluus and allied species. Mycotaxon 44: 155-195. 
Larsson E, Larsson KH (2003). Phylogenetic relationships of russuloid basidiomycetes with emphasis on aphyllophoralean taxa. Mycologia 95: 1037-1065.

Larsson KH, Larsson E, Koljalg U (2004). High phylogenetic diversity among corticioid homobasidiomycetes. Mycological Research 108: 983-1002.

Latha KPD, Raj KNA, Farook VA, et al. (2016). Three new species of Russulaceae from India based on morphology and molecular phylogeny. Phytotaxa 246: 061-077.

Le HT (2007). Biodiversity of the genus Lactarius (Basidiomycota) in northern Thailand. PhD thesis, Chiang Mai University, Thailand.

Le HT, Verbeken A, Nuytinck J, et al. (2007). Lactarius in Northern Thailand: 3. Lactarius subgenus Lactoriopsis. Mycotaxon 102: 281291.

Lebel T, Dunk CW, May TW (2013). Rediscovery of Multifurca stenophylla (Berk.) T.Lebel, C.W.Dunk \& T.W.May, comb. nov. (Russulaceae) from Australia. Mycological Progress 12: 497-504.

Lebel T, Tegart L, Cooper J (2016). Uncovering cryptic species in the Lactifluus clarkeae complex. Abstracts of papers presented the 2016 MSA meeting, Berkeley, California, USA.

Lebel T, Tonkin JE (2007). Australasian species of Macowanites are sequestrate species of Russula (Russulaceae, Basidiomycota). Australian Systematic Botany 20: 355-381.

Leonardi M, Comandini O, Rinaldi AC (2016). Peering into the Mediterranean black box: Lactifluus rugatus ectomycorrhizas on Cistus. IMA Fungus 7: 275-284.

Leonardi M, Furtado ANM, Comandini O, et al. (2020). Halimium as an ectomycorrhizal symbiont: new records and an appreciation of known fungal diversity. Mycological Progress 19: 1495-1509.

Li GJ, Hyde KD, Zhao RL, et al. (2016). Fungal diversity notes 253-366: taxonomic and phylogenetic contributions to fungal taxa. Fungal Diversity 78: 1-237.

Lincoff G (2010). The Complete Mushroom Hunter: An Illustrated Guide to Finding, Harvesting, and Enjoying Wild Mushrooms. Quarry Books: USA.

Linnaeus C (1753). Species Plantarum. Holmiae.

Liu LN, Razaq A, Atri NS, et al. (2018). Fungal Systematics and Evolution: FUSE 4. Sydowia 70: 211-286.

Liu PG, Yu FQ, Wang XH, et al. (2009). The cultivation of Lactarius volemus in China. Acta Botanica Yunnanica, Supplement XVI: 115116.

Looney BP, Ryberg M, Hampe F, et al. (2016). Into and out of the tropics: global diversification patterns in a hyperdiverse clade of ectomycorrhizal fungi. Molecular Ecology 25: 630-647.

Luo DQ, Zhao LY, Shi YL, et al. (2009). Velleratretraol, an unusual highly functionalized lactarane sesquiterpene from Lactarius vellereus. Journal of Antibiotics 62: 129-132.

Maba DL, Guelly AK, Yorou NS, et al. (2015a). Diversity of Lactifluus (Basidiomycota, Russulales) in West Africa: 5 new species described and some considerations regarding their distribution and ecology. Mycosphere 6: 737-759.

Maba DL, Guelly AK, Yorou NS, et al. (2014). Two New Lactifluus species (Basidiomycota, Russulales) from Fazao Malfakassa National Park (Togo, West Africa). Mycological Progress 13: 513-524.

Maba DL, Guelly AK, Yorou NS, et al. (2015b). Phylogenetic and microscopic studies in the genus Lactifluus (Basidiomycota, Russulales) in West Africa, including the description of four new species. IMA Fungus 6: 13-24.

Marchand A (ed) (1980). Champignons du nord et du midi 6. Lactaires et Pholoiotes. Société Mycologique des Pyrénées Méditerranéennes, Perpignan (66000), Perpignan.

Massee G (1914). Fungi exotici XVII. Kew Bulletin: 72-76.
McNabb RFR (1971). The Russulaceae of New Zealand. 1. Lactarius DC ex S.F. Gray. New Zealand Journal of Botany 9: 46-66.

McNeill J, Turland NJ, Monro AM et al. (2011). XVIII International Botanical Congress: Preliminary mail vote and report of Congress action on nomenclature proposals. Taxon 60: 1507-1520.

Miller OK, Lodge DJ, Baroni TJ (2000). New and interesting ectomycorrhizal fungi from Puerto Rico, Mona, and Guana Islands. Mycologia 92: 558-570.

Miller OK, Miller HH (2006). North American Mushrooms A Field Guide To Edible And Inedible Fungi. Rowman \& Littlefield: USA.

Miller SL, Aime MC, Henkel TW (2002). Russulaceae of the Pakaraima Mountains of Guyana. I. New species of pleurotoid Lactarius. Mycologia 94: 545-553.

Miller SL, Aime MC, Henkel TW (2012). Russulaceae of the Pakaraima Mountains of Guyana 2. New species of Russula and Lactifluus. Mycotaxon 121: 233-253.

Miller SL, Larsson E, Larsson KH, et al. (2006). Perspectives in the new Russulales. Mycologia 98: 960-970.

Miller SL, McClean TM, Walker JF, et al. (2001). A molecular phylogeny of the Russulales including agaricoid, gasteroid and pleurotoid taxa. Mycologia 93: 344-354.

Mittermeier RA, Mittermeier CG, Brooks TM, et al. (2003). Wilderness and biodiversity conservation. Proceedings of the National Academy of Sciences USA 100: 10309-10313.

Mlinaric A, Kac J, Fatur T, et al. (2004). Anti-genotoxic activity of the mushroom Lactarius vellereus extract in bacteria and in mammalian cells in vitro. Pharmazie 59: 217-221.

Montoya L, Bandala V (1996). Additional new records on Lactarius from Mexico. Mycotaxon 57: 425-450.

Montoya L, Bandala VM (2004). Studies on Lactarius: a new species from the Gulf of Mexico area. Cryptogamie, Mycologie 25: 15-21.

Montoya L, Bandala VM, Guzmán G (1996). New and interesting species of Lactarius from Mexico including scanning electron microscope observations. Mycotaxon 57: 411-424.

Montoya L, Bandala VM, Haug I, et al. (2012). A new species of Lactarius (subgenus Gerardii) from two relict Fagus grandifolia var. mexicana populations in Mexican montane cloud forests. Mycologia 104: 175-181.

Montoya L, Caro A, Ramos A, et al. (2019). Two new species of Lactifluus (Fungi, Russulales) from tropical Quercus forest in eastern Mexico. MycoKeys 59: 27-45.

Morozova OV, Popov ES, Kovalenko AE (2013). Studies on mycobiota of Vietnam. II. Two species of Lactifluus (Russulaceae) with pleurotoid basidiomata. Mikologiya I Fitopatologiya 47: 92-102.

Murrill WA (1939). Some Florida gill-fungi. Journal of the Elisha Mitchell Scientific Society 55: 361-372.

Murrill WA (1941). More Florida Novelties. Mycologia 33: 434-448.

Nagy B, Maicaneanu A, Indolean C, et al. (2014a). Comparative study of Cd(II) biosorption on cultivated Agaricus bisporus and wild Lactarius piperatus based biocomposites. Linear and nonlinear equilibrium modelling and kinetics. Journal of the Taiwan Institute of Chemical Engineers 45: 921-929.

Nagy B, Szilagyi B, Majdik C, et al. (2014b). Cd (II) and Zn (II) Biosorption on Lactarius piperatus macrofungus: equilibrium isotherm and kinetic studies. Environmental Progress \& Sustainable Energy 33: 1158-1170.

Njouonkou AL, De Crop E, Mbenmoun AM, et al. (2016). Diversity of edible and medicinal mushrooms used in the Noun Division of the West Region of Cameroon. Journal of Medicinal Mushrooms 18: 387-396.

Nuytinck J, D’hooge E, Verbeken A (2013). Lactarius (Russulales) in Europe and North America: some look-alikes tested molecular- and morphologically. Scripta Botanica Belgica 51: 106-116. 
Nuytinck J, De Crop E, Delgat L, et al. (2020). Recent insights in the phylogeny, species diversity and culinary uses of milkcap genera Lactarius and Lactifluus. In: Mushrooms, humans and nature in a changing world: Perspectives from ecological, agricultural and social sciences (Perez J, Guerin A, Flores R, et al. eds). Springer, Cham: 273-286.

Nuytinck J, Verbeken A, Delarue S, et al. (2003). Systematics of European sequestrate lactarioid Russulaceae with spiny spore ornamentation. Belgian Journal of Botany 136: 145-153.

Nuytinck J, Verbeken A, Miller SL (2007). Worldwide phylogeny of Lactarius section Deliciosi inferred from ITS and glyceraldehyde3-phosphate dehydrogenase gene sequences. Mycologia 99: 820832.

O'Brien HE, Parrent JL, Jackson JA, et al. (2005). Fungal community analysis by large-scale sequencing of environmental samples. Applied and Environmental Microbiology 71: 5544-5550.

Oberwinkler F (1977). Das neue System der Basidiomyceten. In: Beiträge zur Biologie der niederen Pflanzen (Frey W, Hurka H, Oberwinkler F, eds). Stuttgart, New York: Gustav Fischer Verlag: 59-104.

Osmundson TW, Halling RE, den Bakker HC (2007). Morphological and molecular evidence supporting an arbutoid mycorrhizal relationship in the Costa Rican Paramo. Mycorrhiza 17: 217-222.

Ozen T, Darcan C, Aktop O, et al. (2011). Screening of antioxidant, antimicrobial activities and chemical contents of edible mushrooms wildly grown in the black sea region of Turkey. Combinatorial Chemistry \& High Throughput Screening 14: 72-84.

Peck CH (1873). Report of the Botanist (1869). Annual Report on the New York State Museum of Natural History 23: 27-135.

Peck CH (1874). Descriptions of new species of fungi. Bulletin of the Buffalo Society of Natural Sciences 1: 41-72.

Peck CH (1879). Report of the Botanist (1878). Annual Report on the New York State Museum of Natural History 32: 17-72.

Peck CH (1885). Report of the Botanist (1884). Annual Report on the New York State Museum of Natural History 38: 77-138.

Peck CH (1896). New species of fungi. Bulletin of the Torrey Botanical Club 23 (10): 411-420.

Peck CH (1898). New species of Alabama fungi. Bulletin of the Torrey Botanical Club 25: 368-372.

Pegler DN, Fiard JP (1979). Taxonomy and ecology of Lactarius (Agaricales) in the Lesser Antilles. Kew Bull 33: 601-628.

Persoon CH (1796). Observationes mycologicae. 1. Germany, Leipzig; Gesnerus, Usterius \& Wolfius.

Persoon CH (1797). Tentamen dispositionis methodica fungorum in classes, ordines, genera et familias cum suppl. adjecta. Lipsiae: Apud Petrum Philippum Wolf.

Phookamsak R, Hyde KD, Jeewon R, et al. (2019). Fungal diversity notes 929-1035: taxonomic and phylogenetic contributions on genera and species of fungi. Fungal Diversity 95: 1-273.

Pimm SL, Joppa LN (2015). How many plant species are there, where are they, and at what rate are they going extinct? Annals of the Missouri Botanical Garden 100: 170-176.

Pons J, Barraclough TG, Gomez-Zurita J, et al. (2006). Sequence-based species delimitation for the DNA taxonomy of undescribed insects. Systematic Biology 55: 595-609.

Rammeloo J, Walleyn R (1993). The edible fungi of Africa south of the Sahara. Scripta Botanica Belgica 5: 1-62.

Redhead SA, Norvell LL (1993). Notes on Bondarzewia, Heterobasidion and Pleurogala. Mycotaxon 48: 371-380.

Rick JE (1906). Pilze aus Rio Grande do Sul (Brazilien). Brotéria Série Botânica 5: 4-53.

Rick JE (1930). Contributio IV ad Monographiam Agaricacearum Brasiliensium. Brotéria Série Botânica 24: 97-118.
Rick JE (1938). Agarici Riograndenses. Lilloa 2: 251-316.

Romagnesi H (1948). Les problèmes et les méthodes de la systématique des champignons supérieurs. Bulletin de la Société Mycologique de France 64: 53-100.

Roody WC (2003). Mushrooms of West Virginia and the Central Appalachians. University Press of Kentucky, Lexington, Kentucky: USA.

Russell B (2006). Field Guide to Wild Mushrooms of Pennsylvania and the Mid-Atlantic. Pennsylvania State University Press, Pennsylvania: USA.

Sá MCA, Baseia IG, Wartchow F (2013). Lactifluus dunensis, a new species from Rio Grande do Norte, Brazil. Mycosphere 4: 261-265.

Sá MCA, Delgat L, Verbeken A, et al. (2019). A new species of Lactifluus (Russulales, Agaricomycetes) from the Brazilian caatinga semiarid region. New Zealand Journal of Botany 57: 169-178.

Sá MCA, Wartchow F (2013). Lactifluus aurantiorugosus (Russulaceae), a new species from Southern Brazil. DARWINIANA, nueva serie 1 54-60.

Sanchez-Garcia M, Henkel TW, Aime MC, et al. (2016). Guyanagarika, a new ectomycorrhizal genus of Agaricales from the Neotropics. Fungal Biology 120: 1540-1553.

Schaefer Z (1979). Beitrag zum Studium der Sektion Albates der Lactarien. Ceska Mykologie 33: 1-12.

Schmit JP, Mueller GM (2007). An estimate of the lower limit of global fungal diversity. Biodiversity and Conservation 16: 99-111.

Scopoli JA (1772). Flora Carniolica exhibens plantas carniolae indigenas et distributas, in classes, genera, species, varietates, ordinae Linneano 2. Vindebonae.

Sevindik M (2020). Antioxidant and antimicrobial capacity of Lactifluus rugatus and its antiproliferative activity on A549 cells. Indian Journal of Traditional Knowledge 19: 423-427.

Sharp C (2011). A pocket guide to mushrooms in Zimbabwe. Volume 1: Some common species, vol 1. Directory Publishers, Bulawayo, Zimbabwe.

Sharp C (2014). A pocket guide to the mushrooms of Zimbabwe. Volume 2: Other common species, vol 2. TWP Sdn. Bhd., Malaysia.

Silva-Filho AGS, Wartchow $F$ (2019). Type studies and new combinations in Brazilian milkcaps (Lactifluus, Russulaceae). New Zealand Journal of Botany 57: 289-308.

Silva AGS, Sa MCA, Komura DL, et al. (2020). Two novel species of Lactifluus subg. Pseudogymnocarpi (Russulaceae) from Brazil. Phytotaxa 436: 222-236.

Singer R (1942). Das System der Agaricales. II. Annales Mycologici 40 : $1-132$.

Singer R (1948). New and interesting species of Basidiomycetes. II. Papers of the Michigan Academy of Sciences 32: 103-150.

Singer R (1952). Russulaceae of Trinidad and Venezuela. Kew Bulletin 7: 295-301.

Singer R (1973). Diagnoses Fungorum Novorum Agaricalium III. Beihefte Sydowia 7: 1-106.

Singer R (1984). Tropical Russulaceae II. Lactarius section Panuoidei. Nova Hedwigia 40: 435-452.

Singer R, Araujo I, Ivory MH (1983). The ectotrophically mycorrhizal fungi of the neotropical lowlands, especially central Amazonia. (Litter decomposition and ectomycorrhiza in Amazonian forests 2.). Beihefte zur Nova Hedwigia 77: 1-352.

Smith ME, Henkel TW, Aime MC, et al. (2011). Ectomycorrhizal fungal diversity and community structure on three co-occurring leguminous canopy tree species in a Neotropical rainforest. New Phytologist 192: 699-712.

Smith P, Allen Q (2004). Field guide to the trees and shrubs of the miombo woodlands. Royal Botanic Gardens, Kew, UK. 
Song Y, Zhang JB, Li JW, et al. (2018). Lactifluus sinensis sp. nov. and L. sinensis var. reticulatus var. nov. (Russulaceae) from southern China. Nova Hedwigia 107: 91-103.

Song Y, Zhang JB, Li JW, et al. (2017). Phylogenetic and morphological evidence for Lactifluus robustus sp. nov. (Russulaceae) from southern China. Nova Hedwigia 105: 519-528.

Stubbe D, Le HT, Wang XH, et al. (2012a). The Australasian species of Lactarius subgenus Gerardii (Russulales). Fungal Diversity 52: 141167.

Stubbe D, Nuytinck J, Verbeken A (2010). Critical assessment of the Lactarius gerardii species complex (Russulales). Fungal Biology 114: 271-283.

Stubbe D, Verbeken A, Wang X-H (2012b). New combinations in Lactifluus. 2. L. subgenus Gerardii. Mycotaxon 119: 483-485.

Taylor JW, Turner E, Townsend JP, et al. (2006). Eukaryotic microbes, species recognition and the geographic limits of species: examples from the kingdom Fungi. Philosophical Transactions of the Royal Society B-Biological Sciences 361: 1947-1963.

Tedersoo L, Bahram M, Jairus T, et al. (2011). Spatial structure and the effects of host and soil environments on communities of ectomycorrhizal fungi in wooded savannas and rain forests of Continental Africa and Madagascar. Molecular Ecology 20: 3071-3080.

Tedersoo L, Bahram M, Polme S, et al. (2014). Global diversity and geography of soil fungi. Science 346: 1256688.

Tedersoo L, May TW, Smith ME (2010a). Ectomycorrhizal lifestyle in fungi: global diversity, distribution, and evolution of phylogenetic lineages. Mycorrhiza 20: 217-263.

Tedersoo L, Nilsson RH, Abarenkov K, et al. (2010b). 454 Pyrosequencing and Sanger sequencing of tropical mycorrhizal fungi provide similar results but reveal substantial methodological biases. New Phytologist 188: 291-301.

Tedersoo L, Sadam A, Zambrano M, et al. (2010c). Low diversity and high host preference of ectomycorrhizal fungi in Western Amazonia, a neotropical biodiversity hotspot. ISME Journal 4: 465-471.

Thiers HD (1957). The Agaric flora of Texas. I. New species of Agarics and Boletes. Mycologia 49: 707-722.

Tian JQ, Wu B, Chen H, et al. (2017). Patterns and drivers of fungal diversity along an altitudinal gradient on Mount Gongga, China. Journal of Soils and Sediments 17: 2856-2865.

Uniyal P, Das K, Adhikari S, et al. (2016). Lactifluus rajendrae sp. nov. (Russulaceae) from India. Phytotaxa 278: 257-264.

Van de Putte K (2012). Hidden diversity exposed: A case study of Lactifluus volemus sensu lato. PhD thesis, Biology, Ghent University, Ghent.

Van de Putte K, De Kesel A, Nuytinck J, et al. (2009). A new Lactarius species from Togo with an isolated phylogenetic position. Cryptogamie, Mycologie 30: 39-44.

Van de Putte K, Nuytinck J, Das K, et al. (2012). Exposing hidden diversity by concordant genealogies and morphology-a study of the Lactifluus volemus (Russulales) species complex in Sikkim Himalaya (India). Fungal Diversity 55: 171-194.

Van de Putte K, Nuytinck J, De Crop E, et al. (2016). Lactifluus volemus in Europe: three species in one - revealed by a multilocus genealogical approach, Bayesian species delimitation and morphology. Fungal Biology 120: 1-25.

Van de Putte K, Nuytinck J, Stubbe D, et al. (2010). Lactarius volemus sensu lato (Russulales) from northern Thailand: morphological and phylogenetic species concepts explored. Fungal Diversity 45: 99-130.

Van Rooij P, De Kesel A, Verbeken A (2003). Studies in tropical African Lactarius species (Russulales, Basidiomycota) 11. Records from Benin. Nova Hedwigia 77: 221-251.
Verbeken A (1995). Studies in tropical African Lactarius species. 1. L. gymnocarpus Heim ex Singer and allied species. Mycotaxon 55: 515-542.

Verbeken A (1996a). New Taxa of Lactarius (Russulaceae) in Tropical Africa. Bulletin du Jardin Botanique National de Belgique 65: 197-213.

Verbeken A (1996b). Studies in tropical African Lactarius species. 3. Lactarius melanogalus Heim and related species. Persoonia 16: 209-223.

Verbeken A (1998). Studies in tropical African Lactarius species. 6. A synopsis of the subgenus Lactariopsis (Henn.) R. Heim emend. Mycotaxon 66: 387-418.

Verbeken A, Buyck B (2002). Diversity and ecology of tropical ectomycorrhizal fungi in Africa. In: Tropical Mycology, Vol. 1: Macromycetes (Watling R, Frankland JC, Ainsworth AM, et al. eds), CABI, UK: 11-24.

Verbeken A, Horak E (1999). Lactarius (Basidiomycota) in Papua New Guinea. 1. Species of tropical lowland habitats. Australian Systematic Botany 12: 767-779.

Verbeken A, Horak E (2000). Lactarius (Basidiomycota) in Papua New Guinea - 2. Species in tropical-montane rainforests. Australian Systematic Botany 13: 649-707.

Verbeken A, Horak E, Desjardin DE (2001). Agaricales of indonesia. 3. New records of the genus Lactarius (Basidiomycota, Russulales) from Java. Sydowia 53: 261-289.

Verbeken A, Nuytinck J (2013). Not every milkcap is a Lactarius. Scripta Botanica Belgica 51: 162-168.

Verbeken A, Nuytinck J, Buyck B (2011). New combinations in Lactifluus. 1. L. subgenera Edules, Lactariopsis, and Russulopsis. Mycotaxon 118: 447-453.

Verbeken A, Stubbe D, Nuytinck J (2008). Two new Lactarius species from Cameroon. Cryptogamie Mycologie 29: 137-143.

Verbeken A, Stubbe D, van de Putte K, et al. (2014). Tales of the unexpected: angiocarpous representatives of the Russulaceae in tropical South East Asia. Persoonia 32: 13-24.

Verbeken A, Van de Putte K, De Crop E (2012). New combinations in Lactifluus. 3. L. subgenera Lactifluus and Piperati. Mycotaxon 120: 443-450.

Verbeken A, Walleyn R (2010). Monograph of Lactarius in tropical Africa. Fungus Flora of Tropical Africa, vol 2. National Botanic Garden, Belgium.

Verbeken A, Walleyn R, Sharp C, et al. (2000). Studies in tropical African Lactarius species. 9. Records from Zimbabwe. Systematics and Geography of Plants 70: 181-215.

Vetrovsky T, Morais D, Kohout P, et al. (2020). GlobalFungi, a global database of fungal occurrences from high-throughput-sequencing metabarcoding studies. Scientific Data 7: 14.

Vrinda KB, Pradeep CK, Mathew S, et al. (2002). Lactarius ignifluus (Russulaceae), a new species from India. Persoonia 18: 129-133.

Wang L, Yang ZL (2006). Wild edible fungi of the Hengduan mountains, Southwestern China. In: Sino-German Symposium 13-17 March 2006. The sustainable harvest of Non-Timber Forest Products in China - strategies to balance economic benefits and biodiversity conservation, Göttingen, Germany, 2006: 58-65.

Wang XH, Buyck B, Verbeken A (2015). Revisiting the morphology and phylogeny of Lactifluus with three new lineages from southern China. Mycologia 107: 941-958.

Wang XH, Halling RE, Hofstetter V, et al. (2018). Phylogeny, biogeography and taxonomic re-assessment of Multifurca (Russulaceae, Russulales) using three-locus data. Plos ONE 13: e0205840.

Wang XH, Hashiya M, Verbeken A (2006). Lactarius ochrogalactus, a new species of the genus Lactarius (Russulaceae, Russulales) with yellowish-brown latex. Mycoscience 47: 232-234. 
Wang XH, Liu PG (2010). Multifurca (Russulales), a genus new to China. Cryptogamie, Mycologie 31: 9-16.

Wang XH, Stubbe D, Verbeken A (2012). Lactifluus parvigerardii sp. nov., a new link towards the pleurotoid habit in Lactifluus subgen. Gerardii (Russulaceae, Russulales). Cryptogamie, Mycologie 33: 181-190.

Wang XH, Verbeken A (2006). Three new species of Lactarius subgenus Lactiflui (Russulaceae, Russulales) in southwestern China. Nova Hedwigia 83: 167-176.

Wartchow F, Bezerra JL, Cavalcanti MAQ (2013). Lactifluus batistae (Russulaceae), a new species from Bahia, Brazil. Agrotrópica 25: 103-108.

Wartchow F, Cavalcanti Q, Auxiliadora M (2010). Lactarius rupestris-a new species from the Brazilian semi-arid region. Mycotaxon 112: 55-63.

Wasser SP (2002). Medicinal mushrooms as a source of antitumor and immunomodulating polysaccharides. Applied Microbiology and Biotechnology 60: 258-274.

Wen HA, Ying JZ (2005). Studies on the genus Lactarius from China II. Two new taxa from Guizhou. Mycosystema 24: 155-158.

Williams M, Ryan CM, Rees RM, et al. (2008). Carbon sequestration and biodiversity of re-growing miombo woodlands in Mozambique. Forest Ecology and Management 254: 145-155.

Wisitrassameewong K (2015). Diversity and phylogeny of Lactarius subgenus Russularia in Southeast Asia. PhD thesis, Department of Biology, Ghent University, Ghent.

Ying YZ (1991). Studies on the genus Lactarius S.F. Gray from China I. New taxa of Lactarius. Acta Mycologica Sinica 10: 190-199.

Yorou NS, Kone NG, Guissou ML, et al. (2014). Biodiversity and Sustainable Use of Wild Edible Fungi in the Sudanian Centre of Endemism. In: Ectomycorrhizal Symbioses in Tropical and Neotropical Forests (Bâ A, McGuire KL, Diédhiou AG, eds). CRC Press, Taylor \& Francis Group, New York: 241-271.

Zhang JB, Huang HW, Qiu LH (2016). Lactifluus dinghuensis sp. nov. from southern China. Nova Hedwigia 102: 233-240.

\section{Supplementary Material: http://fuse-journal.org/}

Figure S1. Overview map of the biogeographical regions used for Table 1. Biogeographic regions are based on biogeographic realms (https:// ecoregions2017.appspot.com/), with three major differences: Western Palearctic (Western part of the Palearctic realm), Asia (Eastern part of the Palearctic realm combined with the Indo-Malay realm), and Australasia (Australasian realm combined with the Oceanian realm). The Palearctic realm was spilt into Western Palearctic and Eastern Palearctic, Eastern Palearctic and the Indo-Malay realm form together the Asia region, and the Australasian realm is combined with the Oceania realm to form the Australasian region.

Table S1. List of described Lactifluus species, together with the year of description, taxonomical classification (subgenus, section), the indication of how this taxonomical position was defined, the source(s) of this classification, and notes.

Table S2. Extra information on the preliminary study of metabarcoding data of the genus Lactifluus, retrieved from the GlobalFungi website.

Table S3. Overview of the results of the preliminary study of metabarcoding data of the genus Lactifluus, retrieved from the GlobalFungi website. Due to the generally shorter length and lower quality of environmental sequence data, the numbers in the table are to be considered an estimate.

Table S4. List of the putative new species found in the environmental sequences. References of studies cited are given in S3. 